\title{
A new look at Eccaparadoxides (Cambrian, Trilobita) and its biostratigraphic significance
}

\author{
Gerd Geyer ${ }^{1}\left[\right.$ [ Ed Landing ${ }^{2} \cdot$ Anna Żylińska ${ }^{3}$
}

Received: 25 January 2021 / Accepted: 31 July 2021

(c) The Author(s) 2021

\begin{abstract}
Eccaparadoxides is a geographically widely distributed trilobite genus that occurs in the middle part of the Cambrian System. However, the systematically important morphologic characteristics that can be used to differentiate taxa are often problematical in their application. A review of the large number (over 30) of significant species or forms assigned to Eccaparadoxides clearly indicates that only the pygidia offer fairly reliable morphologic criteria that can be used taxonomically and phylogenetically. The pygidia allow for recognition of four different morphological groups (pusillus, lamellatus, pradoanus and asturianus) of which the asturianus group can only be questionably assigned to the genus. Species known only from cranidia cannot be assigned to Eccaparadoxides with certainty. This study refines the biostratigraphy for the interval from the upper Wuliuan to the middle Drumian and shows that this interval brackets the range of most Eccaparadoxides species. The genera or subgenera Baltoparadoxides, Rejkocephalus and Macrocerca are evaluated. Eccaparadoxides zelus, E. epimetheus and Eccaparadoxides? hestia are newly proposed species.
\end{abstract}

Keywords Cambrian $\cdot$ Trilobita $\cdot$ Taxonomy $\cdot$ Biostratigraphy $\cdot$ Palaeobiogeography

\section{Introduction}

Eccaparadoxides is a well-known genus (or subgenus) of the Paradoxides clade. Up to 29 species and a number of additional "forms" have been distinguished and assigned, or tentatively assigned, to the genus. The genus was proposed by Šnajdr (1957), when he assigned the Bohemian species of the traditional genus Paradoxides to four genera: Paradoxides Brongniart, 1822; Acadoparadoxides Šnajdr, 1957; Eccaparadoxides Šnajdr, 1957; and Hydrocephalus Barrande, 1846; with Plutonides Hicks, 1895, allied as a

Handling Editor: Xing-liang Zhang.

Gerd Geyer

gerd.geyer@uni-wuerzburg.de

1 Institut für Geographie und Geologie, Lehrstuhl für Geodynamik und Geomaterialforschung, Bayerische JuliusMaximilians-Universität, Am Hubland, 97074 Würzburg, Germany

2 New York State Museum, 222 Madison Avenue, Albany, NY, USA

3 Faculty of Geology, University of Warsaw, Żwirki i Wigury 93, 02-089 Warszawa, Poland fifth genus. Šnajdr's (1957) generic concepts, which were based primarily on Bohemian material, allowed a relatively straightforward distinction between the genera based on the pattern of glabellar furrows, length of palpebral lobes, course of the anterior branches of the facial suture, overall shape of the pygidium and the length and subdivision of the pygidial axis. However, these generic concepts became relatively blurry when all known and subsequently erected paradoxidine species were carefully compared. This resulted in the proposal of additional (sub)genera such as Eoparadoxides Solov'ev, 1969; Baltoparadoxides Šnajdr, 1986; Rejkocephalus Kordule, 1990; and Mawddachites Fletcher, 2007.

A number of studies on these "Acadobaltic" paradoxidines have been published over the past 30 years with different approaches to resolve the difficulties of generic distinctions. However, Eccaparadoxides remained as the least evaluated taxon among them in terms of differentiation, species concepts and biostratigraphy. In this review, the distinction and definition of Eccaparadoxides are evaluated with additional Eccaparadoxides forms described from West Gondwanan areas in Central Europe and the Moroccan Atlas ranges. In addition, this study refines the biostratigraphy for the upper Wuliuan to the middle Drumian, which brackets most of the range of Eccaparadoxides species. 

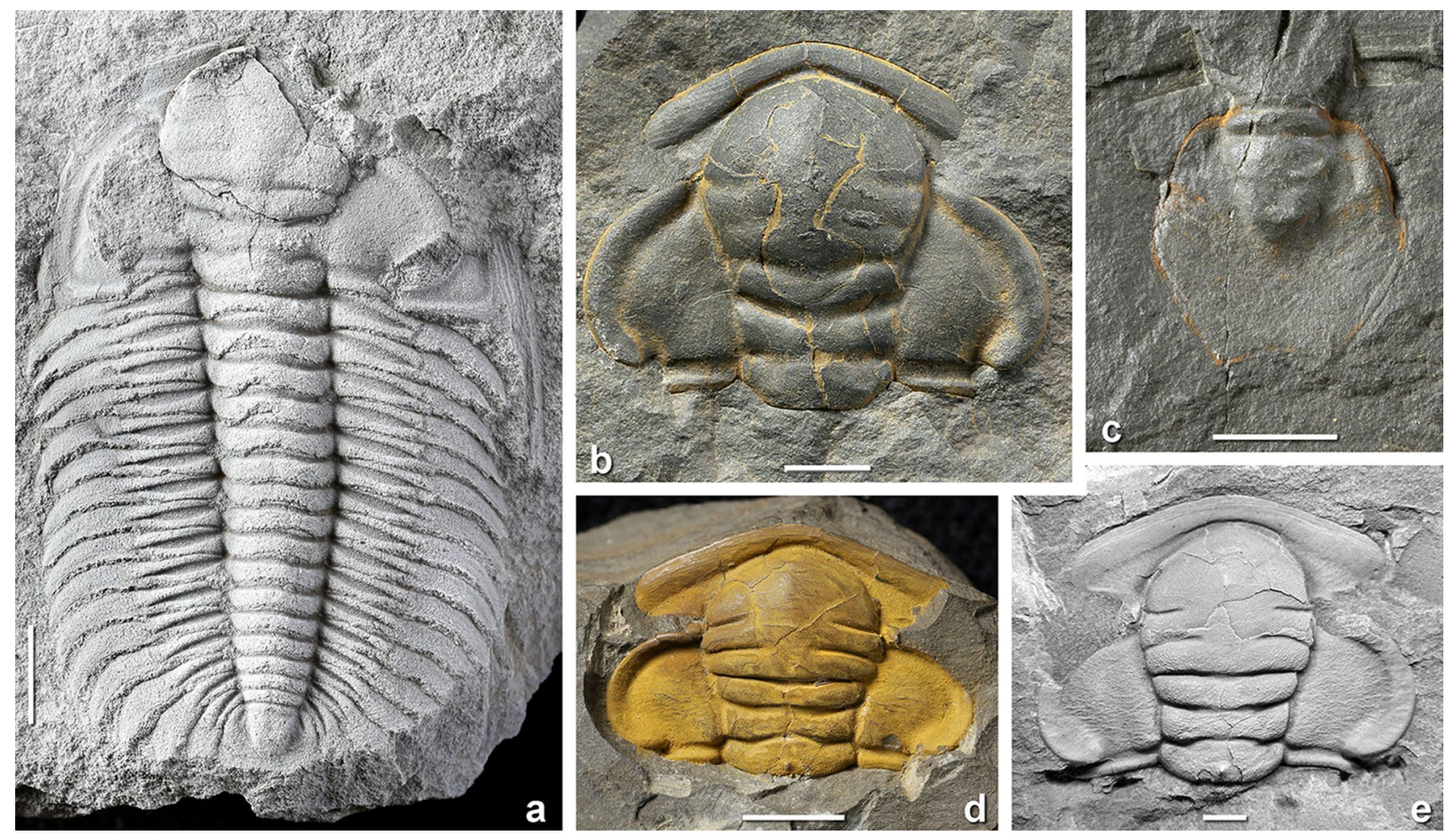

Fig. 1 Eccaparadoxides pusillus (Barrande, 1846). a NM L19567, dorsal exoskeleton, figured in Šnajdr (1958: pl. 22, fig. 3), from locality Slapy/Slapnický mlýn; b NM L12635, relatively large cranidium, figured by Barrande (1852: pl. 13, fig. 4), from locality Slapy/Slapnický mlýn; c NM L16672, pygidium, figured by Barrande (1872: pl. 3, fig. 36), from locality Mlečice; d NM L12633, cranidium of mod-

\section{Šnajdr's concept of Eccaparadoxides and the characterisation of $E$. pusillus}

The genus Eccaparadoxides was proposed by Šnajdr (1957) based on Paradoxides pusillus Barrande, 1846. Šnajdr (1957: 114-115) provided a long diagnosis of the genus, which largely refers to the characters seen in $E$. pusillus, particularly the presence of four pairs of lateral glabellar furrows; a relatively slender posterior part of the glabella; long and conspicuously curved palpebral lobes; short anterior branches of the facial suture, which cause the anterior wings to lie more adaxially than the lateral margins of the palpebral lobes; a subhexagonal outline of the pygidium; a broad pygidial doublure; and a moderately long pygidial axis (e.g., Fig. 1c).

Šnajdr (1957: 115) included Eccaparadoxides harknessi (Hicks, 1871), E. mediterraneus (Pompeckj, 1901) (commonly misspelled "mediteraneus" by Šnajdr), E. brachyrhachis (Linnarsson, 1883), E. insularis (Westergård, 1936) and E. eteminicus (Matthew, 1883) in the genus without reservation. He also tentatively included E.? oelandicus (Sjögren, 1872), "E. sjögreni nepos" erate size, slightly longitudinally compressed, figured by Barrande (1852: pl. 13, fig. 3), from locality Slapy/Slapnický mlýn, original collection of I. A. Hawle; e NM, cranidium of relatively small size with slightly curved S3, from uncertain locality. All specimens in dorsal view, from Jince Formation, Jince-Skryje Basin, Bohemia. Scale bars $5 \mathrm{~mm}$ except for e $(1 \mathrm{~mm})$

(Grönwall, 1902), E.? acadicus (Hartt in Dawson, 1868), E.? pradoanus (Verneuil and Barrande in Prado et al., 1860) and E.? tumidus (Angelin, 1854), as well as the problematic, unrecognizable species E. barrandei (Barrois, 1882) (see Pompeckj 1896). Given the differences in the morphologic characters of these species, this indicates that Šnajdr (1957) had a relatively rigid and narrow concept of Eccaparadoxides in mind.

Eccaparadoxides pusillus (Barrande, 1846) is a wellknown, common species from the Jince Formation of the Přibram-Jince Basin and the Skryje Member of the Buchava Formation in the Skryje-Týrovice Basin in the Bohemicum/ Barrandian region of the Czech Republic (e.g., Fatka 2006; Fatka and Szabad 2014). The known specimens record a surprisingly high morphological plasticity that includes differences of the glabellar outline (ranging from weakly expanding forward to decidedly pear-shaped), the length of the palpebral lobes and their contact with the glabella, and the course of the anterior branches of the facial suture. This variability led to the proposal of a number of species, which are now regarded as synonyms of E. pusillus (e.g., Šnajdr 1957). These synonyms include Hydrocephalus saturnoides Barrande, 1846; Paradoxides inflatus Hawle and 
Corda, 1847 (in part); Phanoptes pulcher Hawle and Corda, 1847; and Paradoxides orphanus Barrande, 1852. Paradoxides rugulosus Hawle and Corda, 1847, is also a synonym of E. pusillus, as it was published in a monograph shortly after Barrande (1846) opus.

However, relatively few pygidia are described and figured from the species, and their morphological variability is uncertain. The pygidia known from Eccaparadoxides pusillus have a subelongate to subhexagonal outline with a truncated posterior margin showing a shallow indentation. The pygidial axis is relatively short, only half the length of the pygidium or less. Only one axial ring is well-defined, with a second one faintly marked (but can be taphonomically enhanced by dorsoventral flattening in some specimens) (Fig. 1). A low median tubercle is occasionally visible on the front of the terminal axial piece.

Among the important characters of the Eccaparadoxides pusillus cranidium, the course and position of the lateral glabellar furrows S3 and S4 are particularly significant. All well-preserved specimens of E. pusillus show that $\mathrm{S} 3$ is slightly longer (tr.) than $\mathrm{S} 4$, with a slightly shallower course near the lateral margins of the glabella and thus forming an indistinct contact with the axial furrow. S4, in contrast, extends to the axial furrows without any associated shallowing so that it is often funnel-shaped laterally (Fig. 1). The palpebral lobes are subequal in width except for the posterior tips and describe a strongly curved arc, with the anterior adaxial portions and the short eye ridges differently developed and located. The eye ridges are arranged at different angles in respect to the main axis, and their adaxial tips meet the axial furrows at different locations: posterior to, directly at, or even slightly anterior to S4.

In addition to the material from Bohemia, the species was identified (or tentatively identified) from several other regions. However, most of the early reports have later been changed, such as the identifications by Brøgger (1878) from the Oslo region, Norway (to "Paradoxides rugulosus") and by Grönwall (1902) from the island of Bornholm (to "Paradoxides rugulosus"). The pygidia from both areas exhibit a bifid posterior margin and certainly do not represent $E$. pusillus (see Dies Álvarez et al. 2010: fig. 2C, 2J, 2K). In addition, the cranidia associated with these pygidia distinctly differ from typical Eccaparadoxides cranidia.

"Paradoxides rugulosus" was also reported from a stratigraphic interval earlier termed the "Paradoxides rugulosus Sandstones" of Comley, Shropshire, UK (Cobbold 1911). The available material is imperfectly preserved, but it is distinctive in that the palpebral lobes are slightly less strongly arcuate than in E. pusillus and the anterior cephalic margin has relatively low curvature. All other recognisable characters are comparable to those seen in E. pusillus. A wellpreserved pygidium assigned to E. pusillus was figured by Cobbold (1911: pl. XIV, fig. 16) and Lake (1935: pl. XXX, figs. 11, 11a), with a suboval outline and a relatively broad posterior margin with a distinctive indentation. The axis is slightly less than half the length of the entire pygidium, and a rearward directed pleural fold is visible. In this respect, the pygidia more closely resemble those of E. zelus sp. nov. from the Delitzsch-Torgau-Doberlug Syncline (see below). However, cranidia associated with the pygidia at Comley are too poorly preserved to allow a confident assessment of their morphology. Additional specimens from Nuneaton, UK, assigned to "Paradoxides rugulosus" by Illing (1916) are distinctly different, and the cranidia may indeed represent a species of Centropleura. In addition, pygidia with a representative morphology that could be assigned to the same species are unknown.

"Paradoxides rugulosus" has also been identified from the Siberian Platform, particularly from the lower Mayan Chaya Formation in the Maya River and Yudoma River areas, Sinsk-Botoma region, and even the Olenek region (e.g., Chernysheva 1965; Astashkin et al. 1992). Although it has even been used as a regional index fossil for the Anopolenus-Paradoxides rugulosus Biozone, the identification appears to have been based only on small cranidia. As pygidia are unknown, the identification must be challenged.

Specimens from drillhole D IV/1928 of the Delitzsch-Torgau-Doberlug Syncline were also described as "Paradoxides rugulosus CORDA" by Schmidt (1944). Sdzuy (1957) regarded this material from northwestern Saxony as a species different from Eccaparadoxides pusillus and dealt with it as "Paradoxides aff. rugulosus". He emphasised that the specimens from Saxony have a cranidium with shorter and less abaxially expanding palpebral lobes and that the flanks adjacent to the pygidial axis are convex rather than flat. Schmidt's original figures (1944: pl. 21, figs. 21-26, pl. 22, figs. 1-20) do not portray the morphology precisely, and Sdzuy (1957) did not figure any specimens. A careful re-examination of the material indicates that the specimens from the Delitzsch-Torgau-Doberlug Syncline represent a species different in pygidial morphology compared with the Bohemian specimens of E. pusillus. However, the high morphologic plasticity of E. pusillus cranidia likely means that the specimens from Saxony fall more or less into its morphological range. Differences exist in the pygidium, which has an outline with curved lateral margins or rounded lateral corners and a strong indentation of the posterior margin in the newly introduced E. zelus sp. nov. (described in detail below under Systematic palaeontology).

A larger number of species must be assigned to the genus than suggested by Šnajdr (1957). However, a mosaic of morphological characters usually defines each species in a more or less characteristic manner so that several, often variable features must be considered in taxonomic work (Figs. 2, 5). The following chapters review all species assigned to Eccaparadoxides in respect to their characters and systematic 


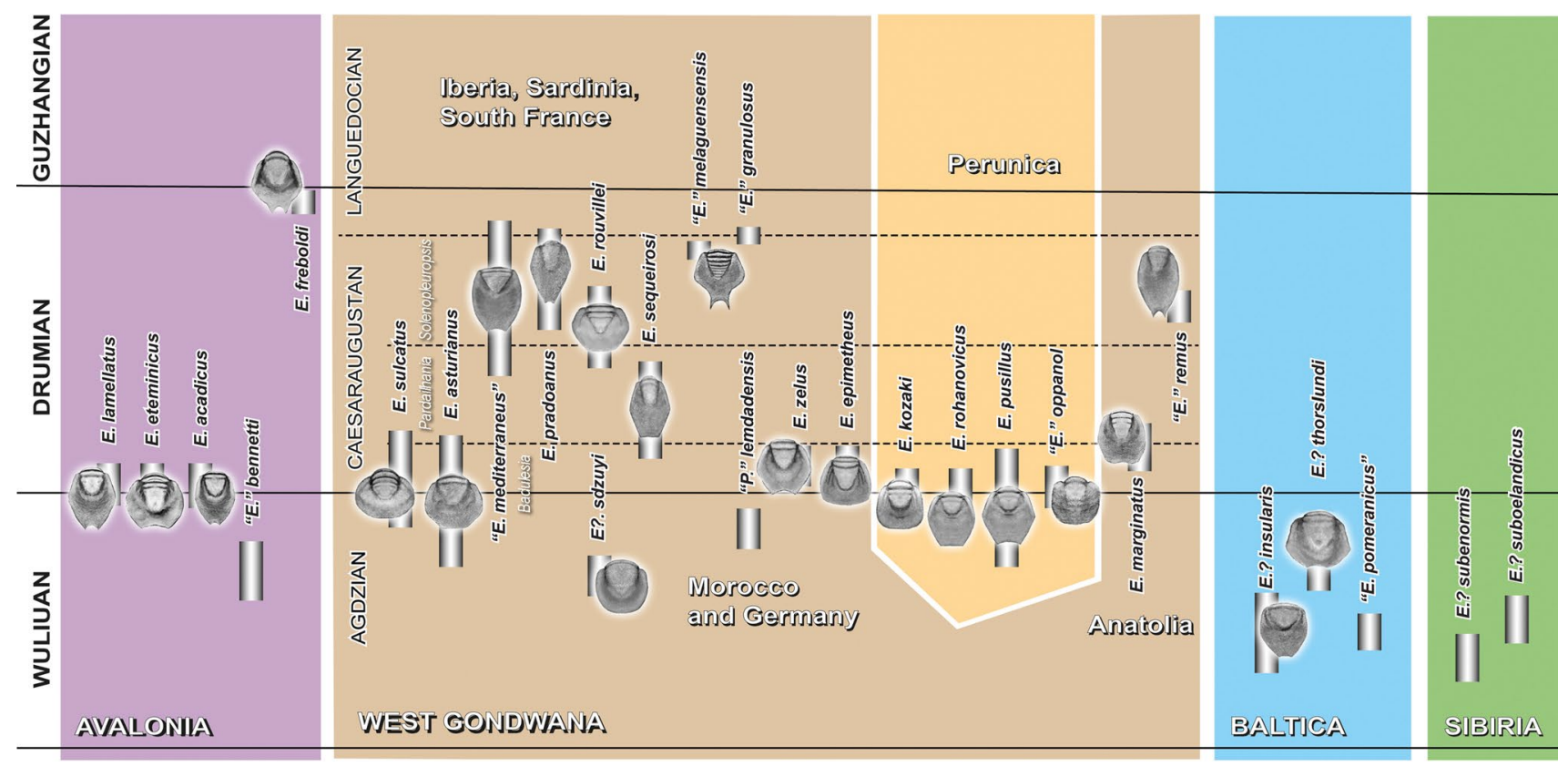

Fig. 2 Approximate stratigraphic ranges of species assigned to Eccaparadoxides with their pygidial morphology and suggested revised taxonomy

affinities. As will be shown in the subsequent sections, a considerable morphological plasticity of cranidial characters is typical for Eccaparadoxides species, particularly during ontogeny. This means that only few cephalic features allow a discrimination of Eccaparadoxides from other taxa of the Paradoxides s.l. clade. These features include: the length and curvature of the palpebral lobes and their continuation into the eye ridges; a relatively slender posterior part of the glabella; distinctly developed glabellar furrows S3 and S4; and an adaxial position of the facial suture. The pygidium is somewhat more typical, having an elongated subhexagonal outline, a transverse posterior margin and a relatively short tapering axis with only one ring clearly marked.

\section{Avalonian taxa}

Eccaparadoxides eteminicus-E. eteminicus (Matthew, 1883 ) is a species from the Fossil Brook Member of the Chamberlain's Brook Formation in the Avalonian areas of New Brunswick and south-eastern Newfoundland. The species, best described and figured in Kim et al. (2002), is characterised by a glabella with a relatively broad (tr.) anterior portion. S3 is distinctly longer than S4, but S4 fades at greater distances from the axial furrow. The palpebral lobes are slightly falcate; the pygidium has a subelongate and relatively broad (tr.) outline, with a wider posterior indentation and fairly distinct tips and with shallow pleural furrows. The species is regarded as showing a considerable morphological plasticity, which prompted Matthew (1883) to name a number of varieties of E. eteminicus based on specimens collected in New Brunswick (i.e., Paradoxides eteminicus var. suricoides, $P$. e. var. breviatus, $P$. e. var. malicitus, P. e. var. quacoensis and $P$. e. var. pontificalis). The differences between them and the type material must be regarded to be a result of compaction during diagenesis, tectonic deformation or just slightly abnormal morphologies so that all "varieties" are now regarded as having no taxonomic value (Kim et al. 2002). However, a possibly different species from New Brunswick was described and figured by Kim et al. (2002: fig. 9.4-9.11) as E. cf. eteminicus.

Eccaparadoxides acadicus-E. acadicus (Matthew, 1883) is another species from the Fossil Brook Member of the Chamberlain's Brook Formation in Avalonian New Brunswick and southeastern Newfoundland. The species is best known from the review by Kim et al. (2002) and is characterised by a normal-type, pyriform glabellar outline. The $\mathrm{S} 3$ furrows are longer than S4, and S4 continues to the axial furrow in a similar way as in E. pusillus; the palpebral lobes are strongly arcuate, with slightly thickened posterior tips; the pygidium has a subelongate and relatively broad (tr.) outline, with an indistinct, narrow posterior indentation only. In addition, the anterior cephalic border shows a considerable broadening (exsag.) towards the facial suture. The species has also been reported from West Gondwana in the Iberian Chains of northern Spain, where it purportedly occurs in an interval from the upper part of the Badulesia granieri and 
the lowermost part of the Pardailhania hispida biozones (Gozalo et al. 2011). However, the known material (Gozalo et al. 2011: fig. 6K, 6L) is fairly distorted and cannot be unequivocally assigned to the Avalonian species.

Eccaparadoxides lamellatus-E. lamellatus (Hartt in Dawson, 1868) also occurs in the Fossil Brook Member of the Chamberlain's Brook Formation in New Brunswick. The species is relatively poorly known from a limited number of specimens, which are considerably distorted. However, its available characters are sufficient to allow a taxonomic distinction. The glabella of E. lamellatus has a typically pyriform glabellar outline. The $\mathrm{S} 3$ furrows are longer than $\mathrm{S} 4$, and $\mathrm{S} 4$ continues to the axial furrow in a similar way as in E. pusillus and E. acadicus. The palpebral lobes are relatively strongly arcuate, with slightly thickened posterior tips, but they seem to have been slightly thicker than those in E. pusillus and E. acadicus. The pygidium has a relatively slender subelongate outline with a narrow, but distinct posterior indentation, and the axis is clearly shorter than half of the pygidial length (Kim et al. 2002: fig. 10.7, 10.8).

Paradoxides bennetti-P. bennetti (Salter, 1859) has been variously assigned to Eccaparadoxides (e.g., Fletcher 2005, 2006). It is a species described from southeastern Newfoundland. It defines the eponymous zone in the lower Chamberlain's Brook Formation in western Avalonia (Fletcher 2006). Its pygidium has an elongated subrectangular outline and an axis of ca. half the length of the pygidium with a welldemarcated anterior axial ring and rudimentary indication of additional axial rings (e.g., Fletcher 2006: pl. 34, fig. 4). It is relatively similar to the pygidium of Eccaparadoxides marginatus Dean, 2005, from Anatolia (see below), but also resembles some pygidia unassigned to species that were tentatively assigned to Acadoparadoxides. The cranidium, however, is dissimilar to that of Eccaparadoxides: It has a regularly pyriform glabella with subequal S3 and S4. The palpebral lobes are moderately long; their posterior tips are located distant from the posterior border furrow, and their maximum width is in a central position. The eye ridges meet the axial furrows posterior to $\mathrm{S} 4$. The anterior border is moderately wide, subevenly curved in its medial part, and the abaxial tips of the border at the facial suture are more or less exactly at the level of the abaxial margins of the palpebral lobes. The species is regarded herein as not referable to Eccaparadoxides.

Paradoxides freboldi-P. freboldi Hutchinson, 1962, is a large species from the upper part of the Manuels River Formation of Avalonian Newfoundland. Hutchinson (1962, tab. 1) claimed the species to be from the " $P$. forchhammeri Zone," i.e., the Guzhangian, but Hutchinson (1962:
117) states that the species "is in the uppermost beds of the davidis zone, and the post-davidis beds." In fact, the species appears to have been found only in the Paradoxides davidis Zone of the upper Drumian and was never confirmed to occur in post-davidis Zone strata, i.e., above the Manuels River Formation. The cranidium of the species has typical Eccaparadoxides characters in its glabella and the relatively adaxial position of the anterior facial suture. The glabella tends to show a slightly "triangular" outline of the frontal lobe with slightly less curved anterolateral margins. The palpebral lobes, however, have only a moderate curvature, are comparatively broad (tr.) in large individuals and relatively short, with their anterior tips at the mid-level of L4, and the eye ridges are steeply anteriorly directed. The anterior cranidial border is clearly elevated and convex in exsagittal and sagittal profile.

Hutchinson (1962: pl. XXIII, figs. 9, 10) figured two incomplete pygidia of different size, both showing a pair of distinct, posteriorly directed posterolateral spines relatively close to each other. Due the different outlines, Hutchinson (1962) distinguished between a broad and a narrow form, but we interpret the differences as a function of allometric growth. The axis with only one well-defined ring occupies ca. 60 percent of the pygidial maximum length. The lateral margin expands from the anterolateral corners in an almost straight course and reaches its maximum width slightly posterior to midlength. Although this morphology with a fairly long axis and a trail-type elongate posterior end of the pygidium with two extended spines is not typical for Eccaparadoxides, the species may be assigned to the genus and is then the youngest known to date.

Paradoxides decorus $-P$. decorus Billings, 1874, is rarely mentioned and was tentatively assigned to Eccaparadoxides (e.g., Sdzuy 1961). This Avalonian species from Trinity Bay, Newfoundland, is known only from Billings' cranidia, which do not show typical characters of Eccaparadoxides. The species is probably based on somewhat differently preserved cranidia of $P$. tenellus Billings, 1874, and must thus be regarded as doubtful.

Paradoxides hicksii-P. hicksii Salter in Salter and Hicks, 1869, another Avalonian species, was originally described from the Whitesands Bay Formation of Caerfai Bay, South Wales, and is known from Porth-y-raw, South Wales. It defines the eponymous zone in the successions (upper Chamberlain's Brook Formation) of southeastern Newfoundland. The species has been occasionally assigned to Eccaparadoxides and designated the type species of a new subgenus of Paradoxides termed Mawddachites by Fletcher (2007). The species is characterised by a cranidium with a strongly forwardly expanding glabella, an anterior border which is extremely narrow on the sagittal line and swings 
conspicuously rearward towards the facial suture. The pygidium has a subcircular outline with a curved posterior margin. Mawddachites was elevated to genus level by Dies Álvarez et al. (2010), who also tentatively assigned the "true" topotypic Swedish P. brachyrhachis (Linnarsson, 1883) to Mawddachites.

A number of specimens from other regions were assigned to "Paradoxides hicksii" or "Plutonides hicksii", but all non-Avalonian specimens are distinguished from the typical Avalonian specimens by characters that exclude a close relationship so that these specimens are not regarded as representing species of Eccaparadoxides. Such specimens assigned to hicksii have been previously identified from the Siberian Platform and this "P. hicksii" was used as an index fossil for the upper Amgan "P. hicksi Biozone" (e.g., Chernysheva 1953, 1965), now termed the Tomagnostus fissus/Paradoxides sacheri Biozone. Westergård (1953) reported "Paradoxides hicksii" from the Tomagnostus fissus-Ptychagnostus atavus Zone of Scania and Bornholm, but the specimens were not figured by him, and it remains uncertain whether he had previously figured specimens from other studies in mind.

Nevertheless, Berg-Madsen (1985) mentioned Hydrocephalus hicksi (sic) from the Lower Alum Shale of Bornholm, obviously from lower lenses of the Tomagnostus fissus-Ptychagnostus atavus Zone noted by Grönwall (1902). As explained in Berg-Madsen (1985), Grönwall (1902) had listed (but not figured) two forms, "Paradoxides Hicksii (var. palpebrosa)" from the Exsulans Limestone (which refers to Linnarsson's 1879 Paradoxides palpebrosus from the Exsulans Limestone of Sweden) and "P. Hicksii" from the lowermost presumed limestone lenses of the Alum Shale, both apparently based on a single specimen. However, Grönwall (1902) mixed the two forms in his descriptions and his list. A re-study of Grönwall's specimens in the collection at the Geological Museum in Copenhagen, Denmark, indicated that the material is from an anthraconite horizon and occurs with Hypagnostus parvifrons and Ptychagnostus punctuosus, indicating that the specimens appar to be redeposited (Berg-Madsen 1985).

However, Weidner and Nielsen (2014) reported a diverse fauna from the Ptychagnostus atavus Zone of Øleå on Bornholm, in which they identified Mawddachites hicksii based on a single incomplete cranidium. This cranidium indeed appears to match all characters known from the cranidia of the Avalonian specimens. However, the reliability of the Bornholm identification suffers from the absence of pygidia.

Szabad and Valíček (1997) reported "Plutonides sp. A" from the middle part of the Eccaparadoxides pusillus Zone of Bohemia, which Vaněk et al. (1999) redescribed as "Plutonides hicksi" (his generic assignment and spelling). Shortly before, Kordule (1999) proposed the new species Eccaparadoxides kozaki, which Vaněk et al. (1999) placed into synonymy with "Plutonides hicksi". We concur that the Bohemian specimens represent a species which should be placed under Mawddachites rather than Eccaparadoxides, but the species is distinctive from $M$. hicksii as discussed below.

Eccaparadoxides harknessi-E. harknessi (Hicks, 1871) occurs in the Solva Beds of the St. David's region, South Wales. The species was based on imperfectly preserved cranidia. Its pygidium. however, is unknown. The only specimen with distinctive characters (Hicks 1871: pl. XV, fig. 9; Lake 1935: pl. XVII, fig. 3) has a pyriform glabella with a relatively broad posterior portion with subparallel lateral margins, faint and nearly unrecognisable S3 and S4, and moderately arcuate palpebral lobes of moderate width. The facial sutures are developed in a way that the abaxial tips of the anterior border are located almost anterior to the abaxial margins of the palpebral lobes. This configuration is not typical for Eccaparadoxides and may indicate that the species is more correctly assignedto Acadoparadoxides, Baltoparadoxides or Plutonides. Given the similarities with Plutonides sedgwicki (Hicks, 1871) (except for the much shorter palpebral lobes) that occurs in the same strata of this area, a tentative assignment to Plutonides appears to be more suitable.

\section{Taxa from the Mediterranean/Cadomian sector and Morocco, West Gondwana}

Numerous West Gondwanan species of Eccaparadoxides have been described, mostly from Iberia and the Montagne Noire range in southern France. Additional species are known from Sardinia and the Saxothuringian Belt in Germany. A new species from core material of the Delitzsch-Torgau-Doberlug Syncline, Saxony, Eccaparadoxides zelus sp. nov., is described below under Systematic palaeontology. Specimens tentatively assigned Eccaparadoxides from the Triebenreuth Formation of the Franconian Forest region, northeastern Bavaria, are too poorly preserved to permit a characterisation of a species (Geyer, unpubl. data).

Eccaparadoxides epimetheus sp. nov. is a common species in the Wuliuan-Drumian boundary interval of the western Anti-Atlas, southern Morocco. Eccaparadoxides? hestia sp. nov. is a stratigraphically significant species from the upper Wuliuan of the High Atlas, southern Morocco. Both are described below under Systematic palaeontology.

Eccaparadoxides pradoanus-E. pradoanus (Verneuil and Barrande in Prado et al., 1860) is recorded from the Oville Formation of the Cantabrian Mountains and the upper part of the Murero Formation in the Iberian Chains, northeastern 
Spain (from the Solenopleuropsis ribeiroi to Solenopleuropsis thorali biozones). A study by Esteve (2014) documented an enormous morphological plasticity of the species, but also raised the question how tectonically distorted specimens of species can be confidently discriminated. It also confirmed the obvious requirement that only corresponding growth stages should be compared. Adult specimens of $E$. pradoanus are characterised by a relatively slender pyriform glabella, S3 being slightly longer than S4, and S4 continuing to the axial furrow, but without a distinct development laterally. The palpebral lobes are moderately arcuate, moderately wide (tr.) and shorter than in most other species of the genus; the eye ridges meet the axial furrows posterior to $\mathrm{S} 4$. The pygidium has a decidedly slender outline with a narrow, but distinct posterior indentation, and the length of the axis is only ca. one-third of the pygidial length.

Eccaparadoxides mediterraneus-E. mediterraneus (Pompeckj, 1901) has been commonly regarded as a widespread West Gondwanan species recorded from the lower Cabitza Formation, southwest Sardinia, Italy (Pompeckj 1901); the Oville Formation of the Cantabrian Mountains (Sdzuy 1961) and the upper part of the Murero Formation and the Borobia Formation in northern Spain (e.g., Sdzuy 1961; Gil-Cid 1970; Liñán and Gozalo 1986; Esteve 2014); the Zafra tectonostratigraphic unit, Ossa-Morena Zone, southern Spain (e.g., Gil-Cid 1982); and the Coulouma Formation of the Montagne Noire, southern France (Courtessole 1973).

Unfortunately, the type material of Pompeckj (1901) does not allow a precise identification of the species. The original specimens seem to have been damaged or lost. Pompeckj (1901: pl. I, figs. 1-3) illustrated three specimens, none of which shows a dorsal view of the cranidium. Pompeckj (1901: pl. I, fig. 1) figured the posterior part of the thorax with the attached pygidium, which is relatively broad. The posterior pygidial margin is distinctly wider than in any of the subsequently described pygidia from Sardinia assigned to Paradoxides/Eccaparadoxides mediterraneus. Pompeckj (1901: pl. I, fig. 3) also illustrated a nearly complete carapace in dorsal view, but with large exfoliated areas, which means only the ventral cast is preserved. The cranidium is also largely removed and now exhibits the cast of a ventrally positioned hypostome. The specimen shows a very slender, almost spindle-shaped pygidium, which has become an iconic feature for the species. It also has a crack along the longitudinal axis of the cranidium and was affected by lateral compression. Therefore, the morphology of this specimen is of little taxonomic significance. Consequently, the precise morphology of the cranidium and the P./E. mediterraneus species sensu Pompeckj (1901) cannot be recognised with certainty. Unfortunately, this specimen was selected as the lectotype by Dies Álvarez et al. (2010), but it is inadequate to confidently characterise the species and identify other specimens from Sardinia, Spain or France. Consequently, the species should be restricted to the holotype. A number of fairly well-preserved, albeit notably distorted specimens from the Cabitza Formation were figured in Dies Álvarez et al. (2010) but seem to show morphological details not visible in the type material of E. mediterraneus and should be regarded as a distinctive new species.

This so-called "Eccaparadoxides mediterraneus" from the Iberian Chains has been the basis of morphologic studies by Esteve (2014) and shown to have a close similarity to E. pradoanus. Esteve (2014) showed that typical pradoanustype pygidia with a very slender outline and a short axis of no more than one-quarter of the pygidial length and a very short (tr.) clipped posterior margin occur in small individuals. By comparison, mediterraneus-type pygidia with a more subovate outline, a longer pygidial axis and a bifid posterior pygidial margin are found only in large specimens. No transitional forms have been figured, and the data for the measured samples appear to indicate a gap for this size range (e.g., Esteve 2014: fig. 20A) so that the taxonomy of this mediterraneus cluster remains uncertain.

Eccaparadoxides asturianus-E. asturianus (Sdzuy, 1968) has been described from the Oville Formation of the Cantabrian Mountains, Asturia, northern Spain, where it occurs in the boundary interval of the "Acadolenus" to "Badulesia n. sp." biozones sensu Sdzuy (1968). This interval was later assigned to the E. asturianus Biozone that defines the upper part of the Leonian Stage of the Iberian regional chronostratigraphy (Sdzuy et al. 1999). This occurrence in

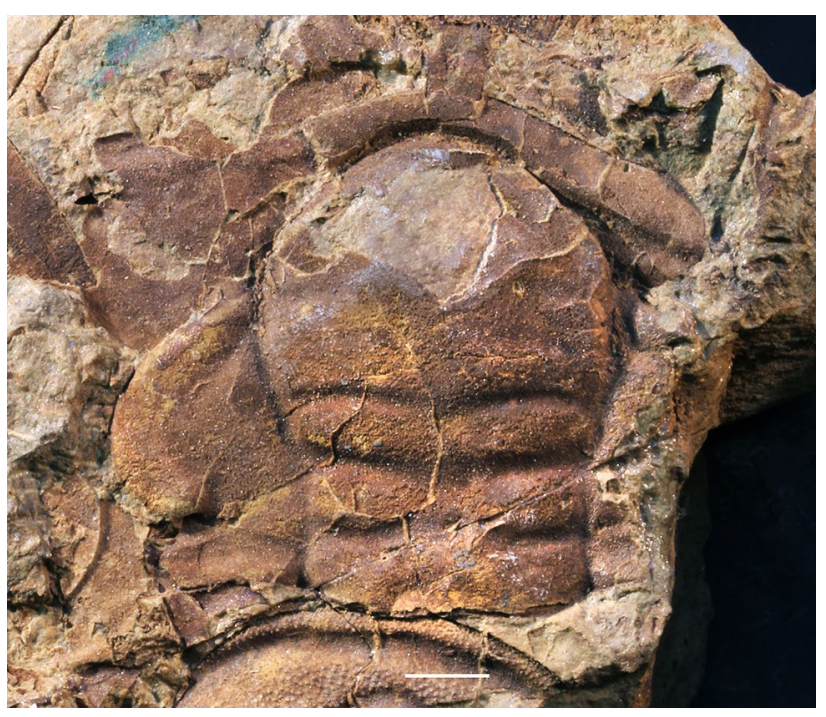

Fig. 3 Eccaparadoxides asturianus (Sdzuy, 1968). Holotype, SMF 24007a, partial pygidium, dorsal view. From Oville Formation, Sebares A section, Cantabrian Mountains, northern Spain. Note faintly bifid palpebral lobe. Scale bar $5 \mathrm{~mm}$ 
sub-Badulesia tenera strata means that it ranks among the older species of Eccaparadoxides. The species has been subsequently reported from the Mansilla Formation of the Iberian Chains, where it is supposed to range upward through the Badulesia tenera and Badulesia granieri biozones into the base of the Pardailhania hispida Biozone (Gozalo et al. 2011). However, the material remains limited, and the morphological variation of the cranidium is unknown.

The holotype and only well-preserved cranidium (Fig. 3) has a relatively broadly pyriform glabella, with $\mathrm{S} 4$ reaching almost to the axial furrows. The palpebral lobes are comparatively broad (tr.), slightly drop-shaped, and comparatively weakly arched, with their anterior parts almost straight and developing into narrow eye ridges that meet the axial furrows at or slightly anterior to S4. The anterior border is moderately broad laterally and stretches almost to the abaxial margins of the palpebral lobes. The pygidium has a broadly subhexagonal outline similar to that of E. pusillus or $E$. acadicus, but with a truncate posterior margin and a pygidial axis with a subtriangular outline and is less than half the length of the pygidium.

Eccaparadoxides sdzuyi-E. sdzuyi (Liñán-Guijarro, 1978) was first described as Paradoxides (Eccaparadoxides) sdzuyus by Liñán-Guijarro (1978) based on material from the Los Villares Formation of the Sierra de Córdoba, southern Spain. Although this original name is etymologically problematical, it does not violate the nomenclatural rules and thus claims priority over the younger designation E. sdzuyi Liñán, 1984 so that this subsequent description is obviously a junior synonym.

Cranidia from the Sierra de Córdoba are reported as occurring relatively frequently, but only one incomplete pygidium was present in the type lot. This was figured only as a line-drawing by Liñán-Guijarro (1978: fig. 43) that shows a semi-elliptical outline and a large axis of ca. three-quarters the length of the pygidium. Although the cranidia are also not well-preserved, it is clear that they are characterised by a regularly pyriform glabella of moderate width; S3 being distinctly longer than S4, which approaches the axial furrow; long, slender and distinctly arcuate palpebral lobes, which meet the axial furrows at or slightly posterior to S4; and a moderately broad anterior border. Noteworthy is a distinct network of caecal venation that covers the fixigenae.

The species was refigured in Gozalo et al. (2008: pl. 2.7, 2.8) with two specimens coming from the Iberian Chains of northern Spain, where it is reported from the Valdemiedes and the Mansilla formations (see Liñán et al. 2004; Gozalo et al. 2008). Gozalo et al. (2008: pl. 2.7, 2.8) show a slightly distorted pygidium assigned to Eccaparadoxides sdzuyi which appears to be similar to the line drawing in LiñánGuijarro (1978: fig. 43), but now shows that the posterior pygidial margin has a slightly convex curvature, and the axis (including a slight posterior raise) occupies more than twothirds of the pygidial length. This type of pygidium is utterly atypical for Eccaparadoxides and much more reminiscent of species of Hydrocephalus. The cranidium figured in Gozalo et al. (2008: pl. 2.7), also from the Iberian Chains, has a moderate size and is characterised by distinctly broader palpebral lobes and narrower fixigenae (tr.) than those from the Sierra de Córdoba in Liñán-Guijarro (1978).

The assumed occurrences of Eccaparadoxides sdzuyi in the Valdemiedes and Mansilla formations have been used to define an Eccaparadoxides sdzuyi Biozone in the biostratigraphic scheme of the Iberian Peninsula, corresponding to the regional Middle Leonian Stage (=middle Agdzian/ middle Wuliuan). This would make $E$. sdzuyi the oldest known Eccaparadoxides. Sdzuy et al. (1999) showed an exceptionally long range of the species, from the base of the eponymous zone across the purported mid-Leonian regression interval up almost to the top of the Eccaparadoxides asturianus Biozone or even the Badulesia tenera Biozone (Gozalo et al. 2011). However, illustrations of the species and its morphologic variation through this long stratigraphic range are not available, and the species must be considered inadequately known and poorly defined through this range.

Eccaparadoxides rouvillei-E. rouvillei (Miquel, 1905) is easily distinguished from all species except the problematic E. sdzuyi by its conspicuous caecal network that covers the fixigenae. The species is further characterised by very large, strongly arcuate and relatively narrow palpebral lobes, which approach the axial furrows opposite S4. The glabella has a typical pyriform outline and a moderate width across the posterior part; $\mathrm{S} 4$ reaches the axial furrow and produces a small embayment. The typical pygidia of E. rouvillei from the Montagne Noire (see Courtessole 1973) are roughly oval to subhexagonal in outline, with gently curved posterolateral "corners" and a low convex curvature of the posterior margin, quite unlike typical Eccaparadoxides species. The pygidial axis tapers considerably rearward and has a distinctly defined anterior ring and a second ring which is only marked by laterally developed furrows. Most pygidia known from Spain show small differences with the pygidia from the Montagne Noire assemblages (see Fig. 5).

The species occurs in the Pardailhania hispida and $P$. multispinosa biozones of the Cabos "Series" of Asturia in the West Asturia-Leonese Zone (Sdzuy 1968), the Murero Formation in the Iberian Chains (Chirivella Martorell 2008; Gozalo et al. 2011) and the Coulouma Formation of the Montagne Noire (Courtessole 1973).

Eccaparadoxides sequeirosi-E. sequeirosi Liñán and Gozalo, 1986, is known from the Murero Formation of the Iberian Chains, northern Spain. It occurs in the upper 
Badulesia granieri Biozone and ranges through the Pardailhania hispida and Pardailhania multispinosa up into the Pardailhania sdzuyi biozones (Chirivella Martorell 2008; Gozalo et al. 2011). The species is known from a number of specimens, but almost all are considerably distorted so that a precise assessment of its morphology is difficult.

Large cranidia are characterised by large, broad glabellas, which are probably the widest in the genus Eccaparadoxides in relation to the cranidial width. The palpebral lobes are strongly arcuate and relatively slender. The eye ridges meet the axial furrows at or slightly posterior to S4. All known pygidia are laterally compressed so that they have a longitudinally elongate outline with more or less uniformly curved lateral margins and a barely recognisable, narrow, slightly truncated posterior margin. The pygidial axis stretches over half the pygidial length or more. These characters suggest that $E$. sequeirosi belongs to a morphological cluster characterised by E. pradoanus and the species presently termed "E. mediterraneus."

Eccaparadoxides sulcatus-E. sulcatus (Liñán and Gozalo, 1986 ) is a little known and obviously rare species that is reported from the E. asturianus, Badulesia tenera and $B$. granieri biozones of the Mansilla Formation in the Iberian Chains, northern Spain. It has been collected from a relatively restricted stratigraphic interval (Liñán and Gozalo 1986; Chirivella Martorell 2008; Gozalo et al. 2011). Its cranidium is characterised by a glabella with an outline that is relatively weakly constricted rearwards. The palpebral lobes are moderately arcuate and moderately thick (tr.), with slightly broader anterior and posterior tips. The eye ridges meet the axial furrows slightly posterior to $\mathrm{S} 4$. The anterior border broadens considerably towards the facial suture, and the intersection of the anterior border and facial suture lies approximately equally distant from the sagittal line as the abaxial parts of the palpebral lobes. The pygidium is poorly known. The only figured pygidium with recognisable morphological characters (Liñán and Gozalo 1986: pl. 12, fig. 4) has a subcircular outline with a gently rounded posterior margin. The pygidial axis is ca. half the pygidial length and seems to have at least two defined axial rings. These characters are more typical for Acadoparadoxides-assigned species, and the species cannot be assigned to Eccaparadoxides.

"Eccaparadoxides brachyrhachis"-The description of Paradoxides brachyrhachis by Linnarsson (1883) marks the start of the biostratigraphic framework of Paradoxides species. The species was originally described from the Alum Shale Formation of Andrarum, Scania, southern Sweden. It is reported from numerous localities in Spain (e.g., Sdzuy 1961; Liñán and Gozalo 1986), particularly in the Solenopleuropsis marginata and S. thorali biozones in the Acón Group of the Iberian Chains. It has also been identified from the Montagne Noire, southern France (Courtessole 1973; often spelled "brachyrachis" in that report). It has been used as a prime example for suggested sexual dimorphism in paradoxidine trilobites (Gozalo et al. 2003).

A revision of the species by Dies Álvarez et al. (2010) sheds new light on the species. The authors restricted the species to a few incomplete cranidia, a partial thorax and two incomplete pygidia. The subtrapezoidal outline of the cranidium, the nearly uniformly broadening glabella and the flat anterior border, as well as several other cranidial characters, the subelliptical pygidium with an axis ca. half the pygidial length and perhaps a curved posterior border suggest that the species cannot be assigned to Eccaparadoxides. Dies Álvarez et al. (2010) tentatively placed the species under Mawddachites.

Consequently, Sdzuy's (1961) assumption that brachyrhachis and mediterraneus had the same type of cephalon and could only be distinguished by the shape of the pygidium is erroneous. Based on their results, Dies Álvarez et al. (2010) suggested that all specimens identified from Iberia and the Montagne Noire as E. brachyrhachis belong to E. mediterraneus (see discussion above). However, unravelling the taxonomic problems is not simple: some of the pygidia from these reports do not fall into the morphological range suggested in the morphometric study by Esteve (2014). In addition, a number of the specimens from Iberia that were earlier assigned to brachyrhachis cannot be grouped into a single species.

As an example, the relatively common paradoxidine specimens from the Caesaraugustan/Drumian of the Láncara Formation in the Cantabrian Mountains mostly differ from the so-called Eccaparadoxides brachyrhachis specimens from the Iberian Chains (e.g., Sdzuy 1961: pl. 20, figs. 1, 14, pl. 21, figs. 3-6, 9). However, some specimens from the Iberian Chains actually do represent this species (e.g., Sdzuy 1961: pl. 21, fig. 8), but differ distinctly from the so-called E. mediterraneus specimens from that region. The name E. brachyrhachis was subsequently listed for specimens from the Cantabrian Mountains without specimens being figured. Figure 4 shows that a distinctive, seemingly new species from the lower and middle Caesaraugustan/lower Drumian is recorded by specimens of the Porma dam section in the Cantabrian Mountains that were referred to as E. brachyrhachis. It has a cranidial morphology, which strikingly differs from the true Scandinavian Mawddachites brachyrhachis, but also from the E. brachyrhachis-type, so-called E. mediterraneus cranidia described from the Iberian Chains (e.g., Sdzuy 1961: pl. 21, figs. 10-12; Dies Álvarez et al. 2010: fig. 4A-D). The glabella is regularly pyriform, with the transverse width across L1 not larger than the transverse width across the occipital ring. The anterior part of the glabella is considerably wider than the occipital ring and its anterior margin 

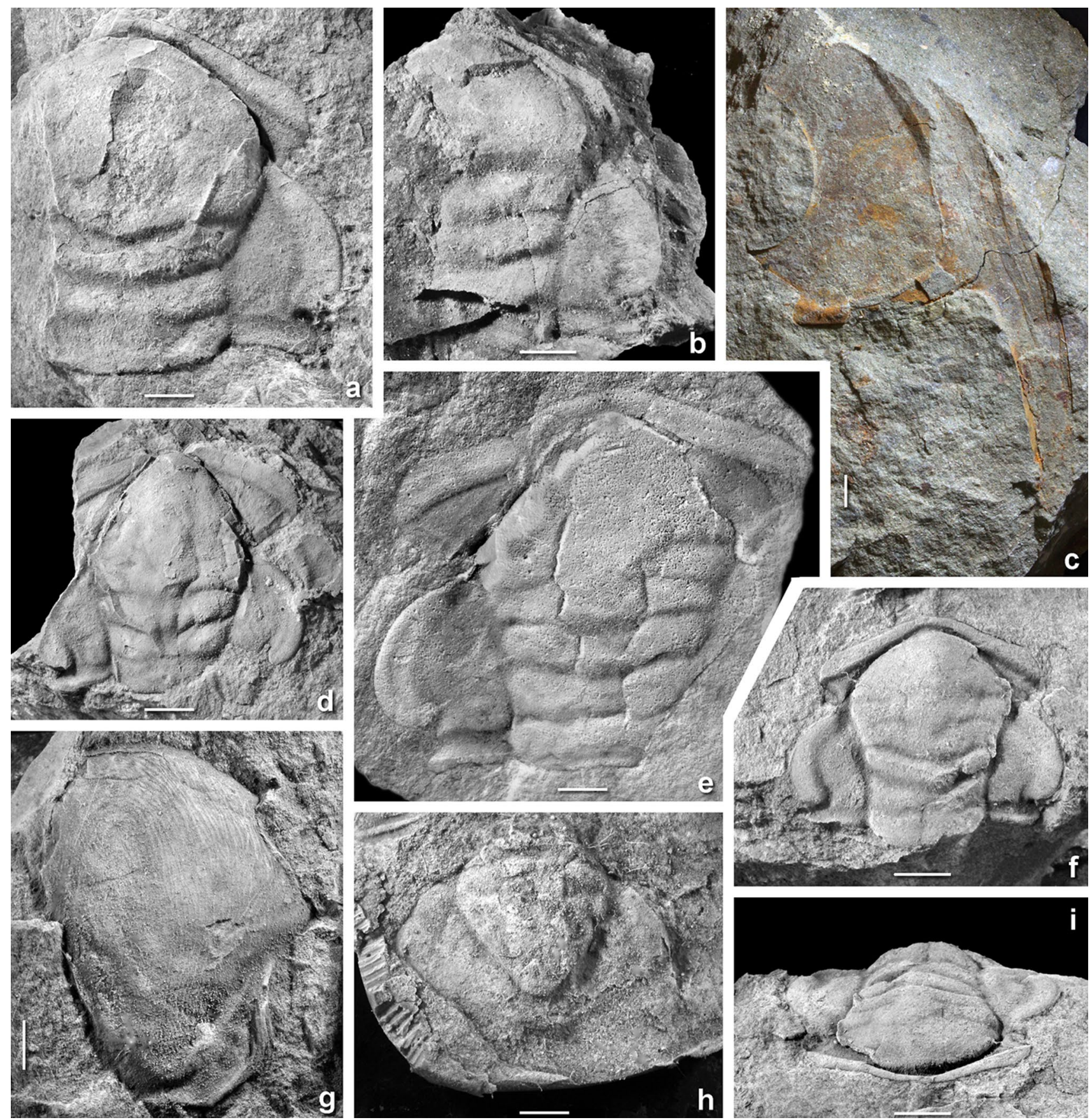

1

Fig. 4 Eccaparadoxides sp. nov. a MMUW 2021-I-067, partial cranidium, internal mould; b MMUW 2021-I-068, partial cranidium, internal mould; c MMUW 2021-I-069, incomplete librigena, internal mould; d MMUW 2021-I-070, incomplete cranidium, internal mould; e MMUW 2021-I-071, cranidium, electronically inversed photo of internal mould; f, i MMUW 2021-I-072, small cranidium, dorsal

and oblique anterior views; g MMUW 2021-I-073, incomplete large hypostome, exterior with terrace lines; h MMUW 2021-I-074, partial pygidium, silicon rubber cast of internal mould. All specimens from Láncara Formation of the Porma dam section, Cantabrian Mountains, a, $\mathbf{c}-\mathbf{h}$ from Badulesia granieri Biozone, $\mathbf{b}$ from Pardailhania hispida Biozone. Dorsal view unless otherwise stated. Scale bars equal $5 \mathrm{~mm}$

tends to develop a slight wedge shape after mild diagenetic compaction and/or tectonic distortion (Fig. 4d, e). The anterior border has a relatively distinct curvature at the sagittal axis, whereas the anterolateral parts are nearly straight, but increase in exsagittal width towards the facial suture. The sagittal and exsagittal profiles of the anterior border indicate a distinct convexity in small/young specimens (Fig. 4f) but it develops into an almost flat, bar-like profile in large individuals (Fig. 4e). The species has relatively narrow fixigenae. 
The most striking characters of the cranidium are related to the morphology of the palpebral lobes. These are distinctly drop-shaped in large specimens, with strongly reduced anterior ends merging into narrow and obliquely directed eye ridges. In addition, a distinct furrow subdivides the adaxial and abaxial parts of the palpebral lobe (Fig. 4d, e). Small individuals have palpebral lobes of subequal width with a clear transverse convexity and therefore lack the median furrow (Fig. 4f). The intersection of the anterior border with the facial suture lies adaxially to the adaxial margin of the palpebral lobe and at its midlength in small individuals. In large specimens, the intersection lies in the middle part of the palpebral lobe or slightly more abaxially, but never beyond the abaxial margin of the circumocular suture as in the E. brachyrhachis-type species from the Iberian Chains (see Dies Álvarez et al. 2010: fig. 4C, D).

No completely preserved pygidia are known from the Porma dam section, but well-preserved and complete pygidia were illustrated by Sdzuy (1961: pl. 21, figs. 3-6, 9) from the Los Barrios de Luna section in the Cantabrian Mountains. They include large sclerites with a short, triangular axis with one axial ring defined by a transglabellar furrow and a second ring indicated by short lateral furrows or a continuous transverse furrow (Fig. 4h). The maximum width is located posterior to the tip of the axis at about midlength of the pygidium. The anterior parts of the pleural fields in the Porma dam species show weak oblique pleural furrows, which are more faintly developed in the Barrios de Luna specimens. The posterior part is long and extends into a pair of long spines separated by a space between them with the outline of an inverted "U". The doublure is very long and reaches forward almost to the axis.

Paradoxides barrandei-P. barrandei Barrois, 1882, reported from the Cantabrian Mountains of north-western Spain (Barrois 1882: pl. IV, fig. 1) and subsequently mentioned as occurring in the Iberian Chains (Sdzuy 1958), is an unrecognisable species which was tentatively assigned to Eccaparadoxides by Šnajdr (1957). A specimen figured as Paradoxides barrandei in Sampelayo (1935: pl. 16, fig. 1) obviously represents a specimen of Eccaparadoxides insularis sensu Dies Álvarez et al. (2010).

Eccaparadoxides melaguesensis-E. melaguesensis (Thoral, 1935) was introduced as a variety of E. mediterraneus based on material from the Solenopleuropsis miqueli-Solenopleuropsis ribeiroi-bearing horizons. It ranges into the Solenopleuropsis verdiagana Zone of the Coulouma Formation in the Montagne Noire (Courtessole 1973). The species is also reported from the Solenopleuropsis marginata and $S$. thorali biozones in the Acón Group of the Iberian Chains. Eccaparadoxides melaguesensis is primarily characterised by a unique outline of its pygidium, which consists of an anterior part with a subelliptical outline that passes into a narrow posterior train with a bifid posterior margin. The posterior tapering causes concave lateral margins in the posterior third. In addition, the axis, which is slightly less than half of the pygidial length, has several posteriorly narrowing axial rings. It should be noted that Courtessole (1973: pl. V, fig. 8) figured a pygidium which we assign in this report to E. melaguesensis. This pygidium has a somewhat broadened posterior train and a comparatively wide terminal bifurcation that Courtessole (1973) referred to E. brachyrhachis ("brachyrachis").

Eccaparadoxides (Macrocerca) macrocercus-E. (M.) macrocercus (Courtessole, 1967) can be regarded as phylogenetically derived from E. melaguesensis, with change in the pygidial morphology. Its pygidium has a slender spatulate outline with the widest portion approximately at onethird of its sagittal length from the front and its posterior end developed into a narrow furca with a fairly long, obliquely backward-directed spine. The pygidial axis is shorter than one quarter of the total pygidial length and has only one well-demarcated axial ring. The cranidium of E. macrocercus has a relatively broad pyriform glabella with subparallel posterior lateral margins and S4 confluent with the axial furrows, but without distinctive incisions. The palpebral lobes are strikingly wide, almost as broad as the relatively small fixigenae and the eye ridges meet the axial furrows posterior to S4. Most important, however, is the anterior border with its slightly curved posterior margin and the abaxial position of the facial suture that allows the anterior border to extend beyond the exsagittal level of the abaxial margins of the palpebral lobes.

The species has a short range in strata with Conocoryphe ferralsensis and Bailiaspis griffei (H1 level) of the La Gardie Formation, Barroubio Group, of the Montagne Noire and is one of the youngest species assigned to Eccaparadoxides. However, the species' pygidial morphology and the course of the facial suture are so different from those of E. pusillus that assignment to Eccaparadoxides is questionable. Courtessole et al. (1988) termed the species E. (Macrocerca) macrocercus. The subgenus Macrocerca is therefore available and could be raised to genus level.

Eccaparadoxides (Macrocerca) garriguensis-E. (M.) garriguensis Pillet, 1988, is another short-ranged species from the La Gardie Formation of the Barroubio Group of the Montagne Noire. It occurs in strata with Dorypyge vizcaïnoi immediately above the range of $E$. macrocercus range (H2 level of Courtessole 1973; see Pillet in Courtessole et al. 1988; Álvaro et al. 1998). The species has a pygidium comparable to that of macrocercus with a conspicuously extended and slender posterior 
section. The cranidium has a facial suture that intersects the anterior border abaxial to the ocular suture. Two pygidia found in the same strata (Courtessole et al. 1988: pl. 3, figs. 8, 11) are characterised by an even longer, beak-like posterior section and probably belong to a different, undescribed species consistent with the Macrocerca-like morphology and emphasises the differences to Eccaparadoxides.

Eccaparadoxides granulosus-E. granulosus (Courtessole, 1967) comes from the Solenopleuropsis rouayrouxi Biozone (E level of Courtessole 1973) of the Coulouma Formation in the Montagne Noire. Its cranidium has a morphology almost without any distinctive characters, with a relatively broad pyriform glabella with subparallel posterior margins. S4 is confluent with the axial furrows. The palpebral lobes are moderately broad to fairly wide; the eye ridges meet the axial furrows immediately posterior to $\mathrm{S} 4$. The name refers to a unique prosopon of small granules that cover the external surface of the cuticle. Unfortunately, the species is based on a single cranidium and no pygidium can be confidently assigned to the species. Consequently, the generic affinity of the species remains uncertain.

“Eccaparadoxides pusillus ?"-Cavet et al. (1967) described numerous specimens of an Eccaparadoxides from the Miaolingian of the remarkable outcrop near Cléré-sur-Layon, Maine-et-Loire Departement, western France. This represents the only known occurrence of paradoxidines in the Armorican Massif. Unfortunately, the preservation of the available, usually fragmentary sclerites is poor. Nevertheless, the shape and dimensions of the glabella, the pattern of the glabellar furrows, the shape and dimensions of the anterior border, and the size and transverse thickness of the palpebral lobes in some of the specimens closely resemble those seen in E. pusillus and the similar E. zelus sp. nov. (described below under Systematic palaeontology). However, significant differences exist in other characters (compare specimens in Cavet et al. 1967: pl. XXII, figs. 1, 2, 3 and pl. XXIII, fig. 2 with those in pl. XXIII, figs. $5,7,8$ ).

The only figured pygidium has a subcircular outline and a long axis of more than three-quarters of the pygidial length and with two more or less well defined axial rings. It is more reminiscent of that of Eccaparadoxides rouvillei and very unlike that of the E. pusillus group (see discussion below). Based on the differences in the characters seen in the cranidia, it should be considered whether two or more species are lumped under "Eccaparadoxides pusillus ?" by Cavet et al. (1967). Accordingly, the pygidium possibly does not belong to the E. pusillus-type cranidia illustrated in that article.
Additional taxa from the Perunica sector of West Gondwana

Eccaparadoxides oppanol-E. oppanol Šnajdr, 1978, is a rare species known from the upper part of the Eccaparadoxides pusillus Zone of the Jince Formation in Bohemia. Its cranidium is superficially similar to that of E. pusillus, nevertheless is clearly different. It is characterised by a relatively slender pear-shaped glabella with relatively shallow S3 and S4. The palpebral lobes are moderately long and do not reach to the posterior border furrow-a character that distinguishes it from all other true species of Eccaparadoxides. Similar features are developed in $E$. kozaki, which is tentatively placed under Mawddachites (see below). The palpebral lobes tend to slightly widen (tr.) rearward, and its posterior tips are distinctly more abaxially located than the anterior tips. The anterior border is narrow and has a convex exsagittal profile even at the facial suture.

The pygidium is not well known. It seems to have a broadly subhexagonal outline, but is relatively broad anteriorly. Its posterior margin is moderately wide and not extended into distinct spines, as so far known. The species has been assigned to Mawddachites but that genus (or subgenus) is still poorly defined, and its type species, $M$. hicksii, differs in having distinctly different glabella and anterior cranidial border.

Eccaparadoxides rohanovicus-E. rohanovicus Šnajdr, 1986 , is another species from the Bohemicum, known from the upper part of the Eccaparadoxides pusillus Assemblage Zone in the Buchava Formation of the Skryje-Týřovice Basin. The species is morphologically similar to E. pusillus and has been frequently confused with it.

The cranidium is pear-shaped and relatively slender, but expands more strongly from S1 forward than in E. pusillus. The lateral glabellar furrows S3 and S4 are comparatively developed to those in specimens of E. pusillus, with S3 longer (tr.) than S4, with a slightly shallower course near the lateral margins of the glabella and thus shows a weakly defined contact with the axial furrow. S4 proceeds to the axial furrows without any decrease in depth, and often shows a slight funnel-shaped outline laterally. The palpebral lobes are subequal in width (except for the posterior tips) and strongly arcuate, with their anterior adaxial portions and the short eye ridges developed differently. The pygidia have a subelongate to subhexagonal outline as those of $E$. pusillus. However, they differ from the pygidia of E. pusillus as the posterior margin is subtruncate and shows a very shallow indentation without distinct lateral spines. The pygidial axis is relatively short and only half 
the length of the pygidium or less. Šnajdr (1986) accentuated that the surface of the cuticle is covered with granules and wavy terrace ridges, unlike those of E. pusillus. The only other species with a distinct granulation is the otherwise different E. granulosus from the Montagne Noire. However, Esteve (2014) emphasised that differences in the prosopon are not a reliable taxonomic character.

Eccaparadoxides kozaki-E. kozaki Kordule, 1999, has a glabella which rapidly expands from S1 forward; it has a slightly unusual outline derived from the common pear shape and is relatively broad. The palpebral lobes are relatively short; their posterior ends are distant from the posterior border furrow. The eye ridges meet the axial furrow just posterior to S4. A unique development is seen in the anterior border, which is thin and thread-like on the sagittal line and directed strongly posteriorly from there, which results in extremely short anterior branches of the facial suture-a character unknown in any other Eccaparadoxides species.

The pygidium of E. kozaki resembles that of Eccaparadoxides/Mawddachites oppanol. It has a broadly subhexagonal outline, but the broadest part lies about one-third of the pygidial length from the posterior end. The shape appears to vary to some extent, but the posterior margin is moderately wide and more-or-less truncated so that lateral spines are not developed. The pygidial axis is subtriangular, poorly subdivided except for one weakly defined ring. Two pygidia figured by Kordule (1999: pl. IV, figs. 10, 11) show oblique pleural furrows near the anterior part of the axis.

The species was introduced by Kordule (1999) and reported to occur in the uppermost part of the Eccaparadoxides pusillus Assemblage Zone in the Buchava Formation of the Skryje-Týrovice Basin in the Bohemicum. Szabad and Valíček (1997) had reported "Plutonides sp. A" ("cf. Plutonides hicksi") from the middle part of the E. pusillus Zone, which Vaněk et al. (1999) shortly after Kordule's publication redescribed as "Plutonides hicksi" (their generic assignment and spelling), and regarded $E$. $k o z a k i$ as a junior synonym of $P$. hicksii. What they indeed meant is that the Bohemian specimens of "E. kozaki" and "P. hicksi" represent the same species. Indeed, this species is more appropriately placed under Mawddachites. However, its pygidial morphology distinctly differs from that of M. hicksii, and features of the cranidium (particularly the outline of the palpebral lobes) differ markedly so that the Bohemian specimens represent a different species, Mawddachites kozaki (Kordule, 1999), as concluded in this report.

\section{Taxa from the Near East sector of West Gondwana}

Eccaparadoxides marginatus-E. marginatus Dean, 2005, is a species from the Badulesia? and Pardailhania zones in the Çal Tepe Formation of the Taurus Mountains, southern Turkey. It has a cranidium with a gently curved anterior margin and a more or less uniformly narrow anterior border. The abaxial tips of the anterior border at the facial suture lie approximately anterior to the distal margins of the palpebral lobes. The glabella is pyriform but has a relatively broad, slightly forward expanding posterior part. It tends to have a subpentagonal shape as it distinctly narrows in front of L4. The palpebral lobes are long, but relatively broad in transverse width, and they extend into relatively transversely directed eye ridges that meet the axial furrow slightly posterior to S4.

The pygidium has a subquadrate outline with almost uniformly curved lateral margins, which is relatively unique for Eccaparadoxides species, with the broadest part opposite or slightly behind the tip of the axis. The axis has a longitudinally triangular shape and at least two well-demarcated axial rings. The posterior margin is more or less exactly transverse or has a minor median indentation.

Eccaparadoxides remus-E. remus (Dean, 1982) is another species from Turkey, described from beds with Solenopleuropsis marginata marginata of the Sosink Formation of the Derik-Mardin region, southeastern Turkey. It is characterised by narrow fixigenae. The palpebral lobes are comparatively thick (tr.) and moderately curved, with the anterior tips relatively posteriorly located and the eye ridges meeting the axial furrows at about the mid-length of L4. As a result, the cranidial width is relatively small, and the maximum width between the abaxial tips of the anterior border is equal or even slightly larger than the distance between the abaxial margins of the palpebral lobes (Dean 1982: fig. 27). These proportions of the cranidium are atypical for Eccaparadoxides and better conform to those of Acadoparadoxides. By contrast, the pygidia attributed to E. remus (Dean 1982: figs. 23, 32, 34) have a conspicuously long and narrow outline and a short pygidial axis, and they distinctly differ from those of Acadoparadoxides. The generic assignment of the species is uncertain.

\section{Taxa from Baltica}

Eccaparadoxides? insularis - E.? insularis (Westergård, 1936) is used as an index fossil of the eponymous zone in the Wuliuan Borgholm Formation in Scandinavia and other areas of Baltica (e.g., the Peribaltic Depression in northern 
Poland; Lendzion 1982; Bednarczyk 1984). The cranidium of E.? insularis has a pyriform glabella of average proportions with a moderate width and subparallel lateral margins posteriorly. The lateral furrows $\mathrm{S} 3$ and $\mathrm{S} 4$ are relatively shallow, $\mathrm{S} 3$ being distinctly longer than $\mathrm{S} 4$, which reaches the axial furrows, but without a lateral expansion. The palpebral lobes are moderately long to long, slightly less curved anteriorly than posteriorly, and extend into forward-directed eye ridges which meet the axial furrows just posterior to $\mathrm{S} 4$. The anterior border is moderately broad (exsag.) and has a flattened dorsal surface, truncated by the facial suture not distinctly adaxially compared with the distal parts of the palpebral lobes.

The pygidium has a slightly longitudinally elongated subhexagonal outline, with an almost evenly curved lateral margin. The posterior margin is subtruncate, with a feeble indentation and without distinct posterolateral corners. The axis has a length of slightly less than half the length of the pygidium; it is weakly subdivided and with a more or less parabolic outline.

The specimens identified as E. insularis in the Holy Cross Mountains of southern Poland appear to show a particularly broad glabella but no pygidium typical of the species has been reported. In addition, the Polish specimens seem to have an older occurrence in the Holy Cross Mountains than those from the type area in southern Sweden (Żylińska and Szczepanik 2009). These specimens have been recently reassigned to the endemic species Acadoparadoxides kozlowskii (Orłowski, 1959a) and bear no resemblance to Eccaparadoxides (Nowicki and Żylińska 2019).

Paradoxides pinus - P. pinus (Holm in Westergård, 1936), known from Öland and Jämtland in Sweden, from the Oslo district in southern Norway, and from the Peribaltic Depression in northern Poland, is usually regarded as a species of Acadoparadoxides. Its glabella has an average pyriform shape with moderate width and subparallel lateral margins in the posterior part. The palpebral lobes are relatively short and thick, and are well defined from the eye ridges. S4 is faint and does not continue to the axial furrow. In addition, the anterolateral corners of the anterior border are situated approximately at the exsagittal level of the abaxial margins of the palpebral lobes.

The pygidium has a shape unlike any typical species of Acadoparadoxides. It has an elongated oval to spindleshaped outline, with a posterior margin having a distinct median indentation. The axis is longitudinally subtriangular and is slightly more than half the length of the pygidium, inclusive of a poorly defined socle.

A number of reports have assigned Paradoxides pinus to Eccaparadoxides (e.g., Dumicz et al. 1970; Bednarczyk 1984; Bengtson and Urbanek 1986; Loi et al. 1995;
Axheimer 2006; Żylińska and Szczepanik 2009; Wolvers and Maletz 2016), but this assignment is even more questionable. The specimens from the Holy Cross Mountains referred to Paradoxides pinus by Orłowski (1959a) and to $P$. (Eccaparadoxides) pinus by Żylińska and Szczepanik (2009) represent the endemic early Acadoparadoxides kozlowskii (Orłowski, 1959a) and A. samsonowiczi (Orłowski, 1959a) (see Nowicki and Żylińska 2019).

Eccaparadoxides pomeranicus-Bednarczyk (1972) proposed an additional species, Eccaparadoxides pomeranicus, from the Paradoxides pinus Zone of the Sarbsko Formation from a drill-core from the Peribaltic Depression in northern Poland. Eccaparadoxides pomeranicus is based only on cranidia, which all represent immature individuals with an Eccaparadoxides morphology (see Bednarczyk 1972, 1984). The specimens have a relatively slender cranidium with long and fairly thin, strongly arcuate palpebral lobes which extend forward into short eye ridges that meet the axial furrow next to the lateral termination of S4. The anterior border is relatively thin (sag., exsag.) and comparatively weakly curved.

This type of cranidium bears some resemblance to those of Eccaparadoxides pusillus, but the glabellar front is clearly distant from the anterior border furrow, with a well-developed preglabellar field in front. Their range of morphology will remain unclear until larger cranidia and pygidia are known. However, the species' occurrence in the same strata as material identified as $P$. pinus raises the question whether $E$. pomeranicus simply includes immature forms of $P$. pinus. In any case, Bednarczyk (1984: pl. I, fig. 4) figured an immature cranidium assigned to $E$. insularis, which shares all of the morphological characters with the juvenile specimens identified as E. pomeranicus (Bednarczyk 1984: pl. II, fig. 2).

In addition, a number of paradoxidines were discovered in the Żarnowiec IG-1 borehole in the Peribaltic Depression in northern Poland. The Eccaparadoxides species are all "classical" Swedish species and include E. insularis, E. oelandicus, E. pinus and P./E. torelli (Pajchlowa 1990). Pygidia are unknown from the specimens identified as $E$. oelandicus and E. pinus, and this identification must be regarded as uncertain based on the cranidial differences with the Swedish specimens. A fairly well preserved cranidium and pygidium are recorded as "P./E. torelli", with the pygidium having a broadly subtriangular outline that cannot be assigned to Eccaparadoxides, but is typical for Acadoparadoxides (Pajchlowa 1990: pl. 18, figs. 2, 3). The specimens from Żarnowiec IG-1 may represent $A$. torelli as described by Asklund and Thorslund (1935), but additional specimens are needed to clarify the morphologic plasticity of that species. 
The cranidium identified as $E$. insularis has a facial suture that intersects the anterior border at a fairly adaxial position as in typical Eccaparadoxides species. In addition, it has moderately long and moderately broad, subequally curved palpebral lobes that end slightly anterior to the occipital furrow, with the anterior tips located opposite the middle of L4. The glabella is fairly narrow posterior part and shows a slightly higher curvature on the sagittal line (Pajchlowa 1990: pl. 16, fig. 7). This morphology suggests the specimen represents a new species. However, additional material is limited, with only a hypostome assigned to the species, which if a pygidium were found, would help clarify the species' taxonomy.

Dumicz et al. (1970) also identified "Eccaparadoxides insularis" from the Khobdo region of western Mongolia, but these specimens certainly represent a different species, which also cannot be assigned to Eccaparadoxides.

Eccaparadoxides? thorslundi-E.? thorslundi Rushton et al., 2016, is known from the "Acadoparadoxides" pinusPentagnostus praecurrens Zone of the Alum Shale Formation of Jämtland, particularly from a block with many exoskeletons of different sizes, making it one of the best known paradoxidine species. It has a characteristic cranidium with a pyriform glabella which has a slender posterior portion and a slightly flattened anterior margin of the frontal lobe. The lateral glabellar furrows S3 and S4 are very faint to obsolescent. The palpebral lobes are fairly thick and generally slightly falcate, widest (tr.) near midlength, with a tapering and less curved anterior portion, which extends obliquely forward into eye ridges that meet the axial furrow opposite S4. The anterior border is unusually similar in exsagittal width throughout its course and has a comparatively low curvature along the anterior cephalic margin.

The pygidium of Eccaparadoxides? thorslundi is highly variable but has a subhexagonal outline, with the lateral corners showing different angles, and with the posterior margin of variable width and depth of indentation. The axis is slightly more than half the length of the pygidium, with an elongate triangular outline and one axial ring. However, well-preserved specimens show additional faint rings. Faint, oblique pleural furrows are visible in the anterior part of the pleura in some specimens. The species is certainly not typical for Eccaparadoxides and shows a mosaic of characters found in Acadoparadoxides, Baltoparadoxides and Eccaparadoxides (see also Nowicki and Żylińska 2019).

Eccaparadoxides torelli-E. torelli (Westergård in Asklund and Thorslund 1935) is a species similar to E.? thorslundi, particularly in the morphology of the pygidium with its subhexagonal outline and with occasional development of an indentation on the posterior margin. It is sometimes assigned to Eccaparadoxides, but certainly shares most characters with typical species of Acadoparadoxides. The specimens from the Holy Cross Mountains assigned to A. torelli by Orłowski (1959a, b, 1964) differ considerably from the species as known from Sweden (as discussed by Weidner et al. 2014). They can be tentatively placed under Hydrocephalus as suggested by Weidner et al. (2014) and Nowicki and Żylińska (2019).

Paradoxides oelandicus-P. oelandicus Sjögren, 1872, was tentatively assigned to Eccaparadoxides by Šnajdr (1957), but has a pygidium with a shape distinctly different from typical species of Eccaparadoxides and a number of cranidial characters that also distinguish it from Eccaparadoxides. Šnajdr (1986) proposed the subgenus Baltoparadoxides of Acadoparadoxides, with P. oelandicus as the type species.

The species has also been reported as Eccaparadoxides oelandicus from the Khobdo region of western Mongolia (Dumicz et al. 1970), but the Mongolian specimens have a suboval pygidial outline unlike the typical pygidia of $\mathrm{Bal}$ toparadoxides oelandicus from Scandinavia.

A number of specimens assigned to Eccaparadoxides oelandicus from the Holy Cross Mountains in Poland (e.g., Orłowski 1957, 1959a, b, 1964; Bednarczyk 1970; Żylińska and Masiak 2007; Żylińska and Szczepanik 2009). This region representing the Trans-European Suture Zone (TESZ) margin of Baltica has been frequently and controversially discussed in terms of its Cambrian palaeogeographic position. Its biogeographic data clearly indicate strong links with West Gondwana (e.g., Żylińska and Masiak 2007; Żylińska 2013; Nowicki and Żylińska 2019). The specimens from this region assigned to Eccaparadoxides oelandicus have been reassigned to Acadoparadoxides kozlowskii (Orłowski, 1959a) and A. samsonowiczi (Orłowski, 1959a) by Nowicki and Żylińska (2019).

Eccaparadoxides? tumidus-E.? tumidus (Angelin, 1854) is a poorly known species from the middle Cambrian of Bornholm. Angelin (1878: pl. III, figs. 2, 2a) figured only one cranidium, which has a rapidly forward tapering glabella, moderately long, obliquely directed palpebral lobes and a strongly recurved anterior border that cannot be assigned to Eccaparadoxides. This specimen appears to be lost, and the species must be regarded as unrecognisable.

\section{Taxa from Sibiria}

Paradoxidines are known from most parts of the Sibiria palaeocontinent, including a large part of the Siberian Platform, the Altay-Sayan Foldbelt (e.g., the Kuznetsk Alatau and Tuva) as well as Mongolia. Although a fairly large number of species have been proposed (with several of them 
assigned to Eccaparadoxides, see below), their taxonomy is in a preliminary state, with several of the species known only from very limited material, often without any information on the pygidium.

Eccaparadoxides cultus-E. cultus (Egorova, 1967) was described as Paradoxides cultus from the Paradoxides cultus - Popigaia popigaia Zone of the Amgan/Wuliuan in the western Prianabar region of the Siberian Platform. Its cranidium is more or less typical of Acadoparadoxides. The glabella is moderately large and similar to the cranidia of the earliest Acadoparadoxides species known from Morocco, Iberia and the Holy Cross Mountains of Poland (e.g., A. pampalius or A. levisettii; Geyer and Vincent 2015), particularly in the shape of the pyriform glabella that slowly expands forward between S1 and S2, with faint S3 and S4, relatively weakly curved palpebral lobes and narrow fixigenae, and the course of the anterior branch of the facial suture. The pygidium, however, has a longitudinally extended, subrectangular outline with rounded posterolateral corners and an axis of ca. two-thirds the length of the pygidium, which leaves space only for narrow pleural fields (Egorova and Savitskiy 1969: pl. 21, figs. 1-6). Its generic affinity is uncertain, but the species' cranidial character suggest that it cannot be assigned to Eccaparadoxides.

Paradoxides eopinus-P. eopinus Solov'ev, 1969, from the Oryctocara Zone of the Amgan in the Nekekit River area, eastern Siberian Platform has a pygidium with a longitudinally extended subhexagonal outline, with long, almost straight posterolateral margins and a moderately broad, weakly curved posterior margin confluent at rounded corners with the posterolateral margin. The subtriangular axis is slightly more than half the pygidial length; it has one welldefined axial ring and ca. two more faint rings posterior to it. The pygidium recalls typical pygidia of Eccaparadoxides, but the differences suggest that this may be a convergent morphology. The cranidium of $P$. eopinus is clearly different from those of true Eccaparadoxides species in having shorter, distinctly drop-shaped, posteriorly broadened palpebral lobes; relatively long, forwardly directed eye ridges; a nearly evenly curved anterior margin of the cranidium; and the abaxial tips of the anterior border located anterior to the abaxial margin of the palpebral lobe (see Egorova and Savitsky in Egorova et al. 1976: pl. 45, figs. 6, 7, 9, 10). The pygidium is fairly unique in its outline. It is relatively slender, with the broadest part ca. one-third from the anterior, with the posterolateral margin barely curved and proceeding subangularly into the subtransverse, slightly curved posterior margin (Egorova and Savitsky in Egorova et al. 1976: pl. 45, fig. 13).
Eccaparadoxides subenormis-E. subenormis (Solov'ev, 1988) was proposed as Paradoxides (E.) subenormis from the Ovatoryctocara Zone of the Kuonamka Formation, Amgan Stage, of the Udzha and Malaya Kuonamka regions of the northern Siberian Platform. It is characterised by a cranidium with a moderately broad (tr.) glabella that expands relatively evenly forward and has weakly developed S3 and S4. The palpebral lobes are long and moderately arcuate, moderately wide (tr.) and faintly falcate. They continue into the eye ridges without distinct differences and meet the axial furrows approximately opposite $\mathrm{S} 4$. The anterior border is thin on the sagittal line and expands to a moderate width at the facial sutures, and is distinctly elevated except in compressed specimens. The abaxial parts of the anterior border at the facial suture are close to the exsagittal level of the abaxial margins of the palpebral lobes. Pygidia of this species appear to be unknown, which precludes a confident assignment to any of the genera of the Paradoxides clade. The cranidial morphology is not similar to that of the type species E. pusillus and E. subenormis cannot assigned to Eccaparadoxides.

"Paradoxides" immanis_-"P." immanis Solov'ev, 1969, is a rare species occurring in the uppermost Ovatoryctocara and lowest Kuonamkites zones of the Kuonamka Formation of the Olenek Uplift, northern Siberian Platform. It was assigned to Eccaparadoxides by Solov'ev (1969), but differs distinctly from unequivocal species of this genus. The cranidium has a glabella with a distinctly subpentagonal shape similar to that of E. marginatus Dean, 2005, but with its anterior end forming a broad and low anterior border that suggests the morphology of Anabaraspis. The palpebral lobes are moderately broad.

The pygidium has a subtriangular, posteriorly expanding outline with a wide (tr.), obviously denticulate posterior margin. The pygidial axis is subrectangular in outline with a gently curved posterior margin (Korovnikov and Shabanov 2016: pl. II, figs. 9-11). This morphology does not suggest assignment to any of the named paradoxidine genera. The best resemblance appears to exist with Baltoparadoxides.

Eccaparadoxides hyperboreus-E. hyperboreus (Lermontova, 1940) is an incompletely known species first described from Novaya Zemlya. It is based only on cranidia with broadly expanding anterolateral wings of the anterior border and a fairly expanded anterior lobe of the glabella (e.g., Egorova et al. 1982: pl. 54, fig. 11). The generic identity is uncertain, but according to the known cephalic characters the species cannot be assigned to Eccaparadoxides. 
Table 1 Species assigned to Eccaparadoxides and their taxonomic position as revised herein

\begin{tabular}{|c|c|c|c|}
\hline Species & Author, year of introduction & Suggested generic affinity & Regional occurrence \\
\hline acadicus & Hartt in Dawson, 1868 & Eccaparadoxides of the lamellatus group & New Brunswick, Newfoundland \\
\hline asturianus & Sdzuy, 1968 & Uncertain, characterises asturianus group & Spain \\
\hline barrandei & Barrois, 1882 & Unrecognisable species & Spain \\
\hline bennetti & Salter, 1859 & $\begin{array}{l}\text { Uncertain generic affinity, not assignable } \\
\text { to Eccaparadoxides }\end{array}$ & Newfoundland \\
\hline brachyrhachis & Linnarsson, 1883 & Mawddachites? & Sweden \\
\hline cultus & Egorova, 1967 & $\begin{array}{l}\text { Uncertain generic affinity, not assignable } \\
\text { to Eccaparadoxides }\end{array}$ & Siberian Platform \\
\hline decorus & Billings, 1874 & Possibly synonym of tenellus & Newfoundland \\
\hline eopinus & Solov’ev, 1969 & $\begin{array}{l}\text { Uncertain generic affinity, not assignable } \\
\text { to Eccaparadoxides }\end{array}$ & Siberian Platform \\
\hline epimetheus & this study & Eccaparadoxides of the pusillus group & Morocco \\
\hline eteminicus & Matthew, 1883 & Eccaparadoxides of the lamellatus group & New Brunswick, Newfoundland \\
\hline freboldi & Hutchinson, 1962 & Possibly species of Eccaparadoxides & Newfoundland \\
\hline garriguensis & Pillet, 1988 & Macrocerca & southern France \\
\hline granulosus & Courtessole, 1967 & Uncertain generic affinity & southern France \\
\hline harknessi & Hicks, 1871 & Tentatively assigned to Plutonides & Wales \\
\hline hestia & this study & Tentatively assigned to Eccaparadoxides & Morocco \\
\hline hicksii & Salter in Salter and Hicks, 1874 & Mawddachites (type species) & Wales, Newfoundland \\
\hline hyperboreus & Lermontova, 1940 & $\begin{array}{l}\text { Uncertain generic affinity, not assignable } \\
\text { to Eccaparadoxides }\end{array}$ & Novaya Zemlya \\
\hline immanis & Solov’ev, 1969 & $\begin{array}{l}\text { Uncertain generic affinity, possibly spe- } \\
\text { cies of Acadoparadoxides (Baltopara- } \\
\text { doxides) }\end{array}$ & Siberian Platform \\
\hline inflatus & Hawle and Corda, 1847 & Partly synonym of pusillus & Bohemia \\
\hline insularis & Westergård, 1936 & $\begin{array}{l}\text { Uncertain, tentatively assigned to Ecca- } \\
\text { paradoxides }\end{array}$ & Sweden, Denmark, Peribaltic Depression \\
\hline kozaki & Kordule, 1999 & Species of Mawddachites & Bohemia \\
\hline lamellatus & Matthew, 1883 & Eccaparadoxides of the lamellatus group & New Brunswick, Newfoundland \\
\hline macrocercus & Courtessole, 1967 & Macrocerca (type species) & southern France \\
\hline marginatus & Dean, 2005 & $\begin{array}{l}\text { Eccaparadoxides?, probably member of } \\
\text { the pradoanus group }\end{array}$ & Turkey \\
\hline mediterraneus & Pompeckj, 1901 & $\begin{array}{l}\text { Eccaparadoxides, restricted to type mate- } \\
\text { rial, others yet unnamed new species of } \\
\text { the pradoanus group }\end{array}$ & $\begin{array}{l}\text { Sardinia, unnamed new species from } \\
\text { Sardinia, southern France and Spain }\end{array}$ \\
\hline melaguesensis & Thoral, 1935 & Probably species of Macrocerca & southern France, Spain \\
\hline mongolicus & Tomczykowa in Dumicz et al., 1970 & $\begin{array}{l}\text { Uncertain generic affinity, not assignable } \\
\text { to Eccaparadoxides }\end{array}$ & Western Mongolia \\
\hline oelandicus & Sjögren, 1872 & Acadoparadoxides (Baltoparadoxides) & Sweden \\
\hline oppanol & Šnajdr, 1978 & $\begin{array}{l}\text { Possibly Eccaparadoxides of the pusillus } \\
\text { group }\end{array}$ & Bohemia \\
\hline orphanus & Barrande, 1852 & Synonym of pusillus & Bohemia \\
\hline pinus & Holm in Westergård, 1936 & $\begin{array}{l}\text { Uncertain, tentatively assigned to Acado- } \\
\text { paradoxides }\end{array}$ & Sweden, Norway, Peribaltic Depression \\
\hline pomeranicus & Bednarczyk, 1984 & $\begin{array}{l}\text { Uncertain, possibly based on juvenile } \\
\text { individuals of pinus }\end{array}$ & Peribaltic Depression \\
\hline pradoanus & Verneuil and Barrande, 1860 & $\begin{array}{l}\text { Eccaparadoxides?, characterises pra- } \\
\text { doanus group }\end{array}$ & Spain \\
\hline pulcher & Hawle and Corda, 1847 & Synonym of pusillus & Bohemia \\
\hline pusillus & Barrande, 1846 & Eccaparadoxides (type species) & Bohemia \\
\hline remus & Dean, 1982 & $\begin{array}{l}\text { Eccaparadoxides?, member of the pra- } \\
\text { doanus group }\end{array}$ & Turkey \\
\hline rohanovicus & Šnajdr, 1986 & Eccaparadoxides of the pusillus group & Bohemia \\
\hline
\end{tabular}


Table 1 (continued)

\begin{tabular}{|c|c|c|c|}
\hline Species & Author, year of introduction & Suggested generic affinity & Regional occurrence \\
\hline rouvillei & Miquel, 1905 & $\begin{array}{l}\text { Uncertain, possibly member of the } a s t u \text { - } \\
\text { rianus group }\end{array}$ & southern France, Spain \\
\hline rugulosus & Hawle and Corda, 1847 & Synonym of pusillus & Bohemia \\
\hline ruminatus & Fedyanina in Chernysheva, 1971 & $\begin{array}{l}\text { Uncertain generic affinity, not assignable } \\
\text { to Eccaparadoxides }\end{array}$ & Altay-Sayan Foldbelt \\
\hline saturnoides & Barrande, 1846 & Synonym of pusillus & Bohemia \\
\hline sdzuyus/sdzuyi & Liñán-Guijarro, 1978 & $\begin{array}{l}\text { Uncertain, probably member of the } \\
\text { asturianus group }\end{array}$ & Spain \\
\hline sequeirosi & Liñán and Gozalo, 1986 & $\begin{array}{l}\text { Eccaparadoxides?, member of the pra- } \\
\text { doanus group }\end{array}$ & Spain \\
\hline subenormis & Solov'ev, 1988 & $\begin{array}{l}\text { Uncertain generic affinity, not assignable } \\
\text { to Eccaparadoxides }\end{array}$ & Siberian Platform \\
\hline suboelandicus & Poletaeva, 1955 & $\begin{array}{l}\text { Uncertain generic affinity, not assignable } \\
\text { to Eccaparadoxides }\end{array}$ & Altay-Sayan Foldbelt \\
\hline sulcatus & Liñán and Gozalo, 1986 & $\begin{array}{l}\text { Uncertain, member of the asturianus } \\
\text { group }\end{array}$ & Spain \\
\hline thorslundi & Rushton et al., 2016 & $\begin{array}{l}\text { Uncertain, possibly species of Acado- } \\
\text { paradoxides (Baltoparadoxides) }\end{array}$ & Sweden \\
\hline torelli & $\begin{array}{l}\text { Westergård in Asklund and Thorslund, } \\
1935\end{array}$ & $\begin{array}{l}\text { Uncertain, possibly species of Acado- } \\
\text { paradoxides }\end{array}$ & Sweden \\
\hline tumidus & Angelin, 1854 & Unrecognisable species & Denmark \\
\hline zelus & this study & Eccaparadoxides of the pusillus group & Germany \\
\hline
\end{tabular}

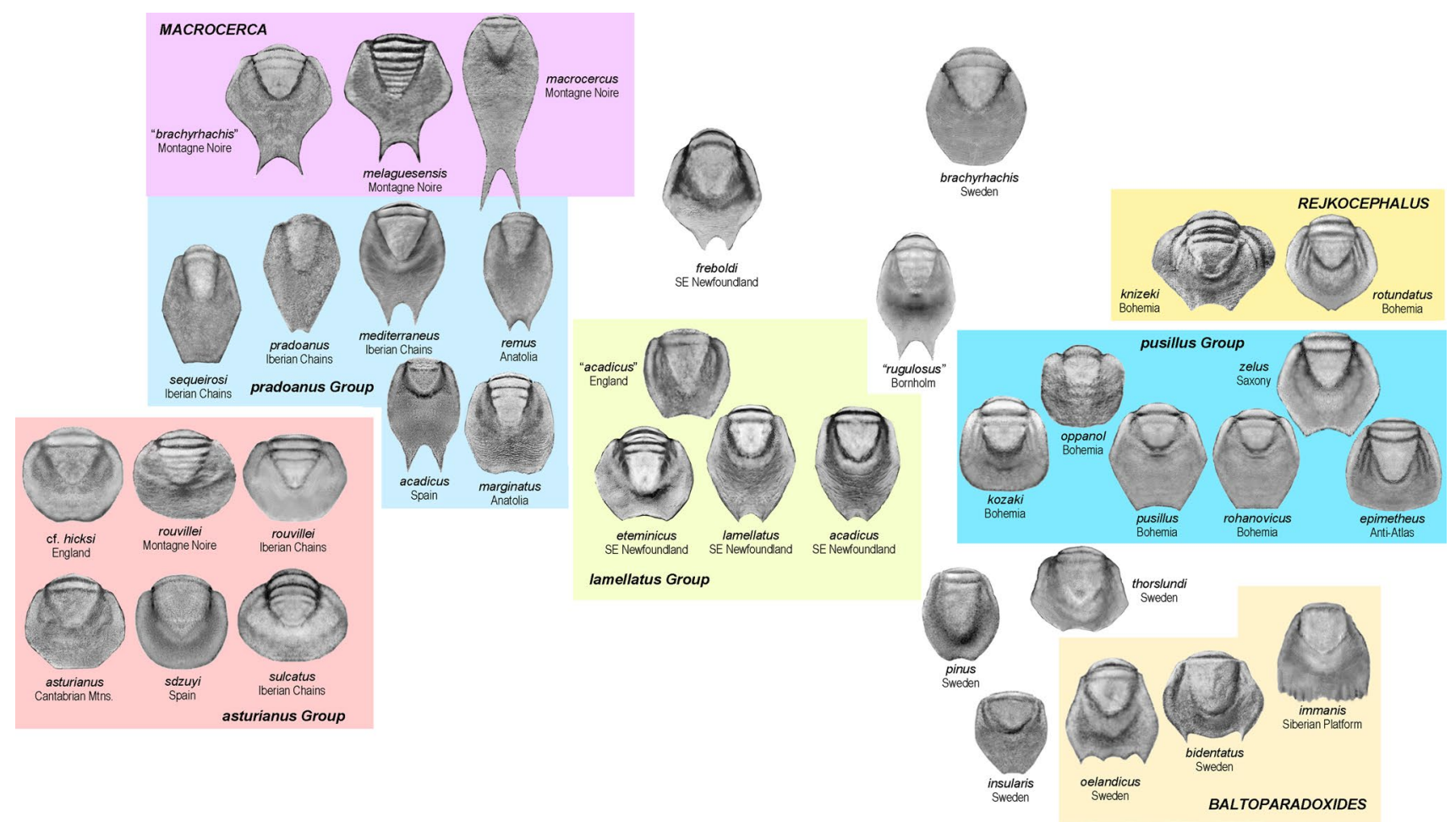

Fig. 5 Morphological groups recognised for species assigned to Eccaparadoxides exemplified by the species' pygidium. Explanations in the text 
Eccaparadoxides ruminatus-E. ruminatus (Fedyanina in Chernysheva, 1971) from the Suyarik "Horizon", Amgan Stage of the Ambas River area, Gornaya Shoriya Range, Altay-Sayan Foldbelt, is known only from a few cranidia. The glabella is relatively broad (tr.) and expands considerably even in the posterior part, with faintly developed S3 and S4, and a fairly long (sag., exsag.) occipital ring. The palpebral lobes are long but thick (tr.) and have only a moderate curvature. The anterior border is almost uniformly curved and expands only weaktly from the sagittal line to the facial suture, which cuts the anterior border at about the level of the palpebral furrow. These characters do not correspond to typical species of Eccaparadoxides. Given limited morphologic information and characters atypical for Eccaparadoxides, the species should be dealt with as Paradoxides s. 1. until the pygidial morphology is known and allows a more precise assignment.

Eccaparadoxides mongolicus-E. mongolicus Tomczykowa in Dumicz et al. 1970, was found in strata assigned to the "lower part of the Eccaparadoxides oelandicus zone" of the Khobdo region of western Mongolia (Dumicz et al. 1970: 298). The available specimens are all laterally compressed cranidia with a moderately wide, slightly expanding glabella with a broad (tr.) posterior part. The palpebral lobes are relatively thick and moderately curved, with their posterior tips distinctly more abaxially positioned than the anterior tips. Its pygidia are unknown. The generic affinity of this species and its distinction from other paradoxidines remains uncertain, but the available data do not suggest an assignment to Eccaparadoxides.

\section{Additional taxa from the Altay-Sayan Foldbelt}

Several paradoxidines have been described from the Altay-Sayan Foldbelt, but none of them is completely known and none has characters that suggest an unequivocal assignment to Eccaparadoxides. They include Paradoxides (Eccaparadoxides) hyperboreus (Lermontova, 1940) from the Wuliuan of the Kuznetsk Alatau; "P. (E.) pradoanus" from the Wuliuan of the Kuznetsk Alatau (contrasting the younger stratigraphic range of the species in Iberia); and " $P$. (E.) mureroensis" from the Wuliuan of the Ulug-Khem River area of Tuva.

The only endemic species of the Altay-Sayan Foldbelt is Eccaparadoxides suboelandicus Poletaeva, 1955, which was first described from the Mundybash River area of Gornaya Shoriya (Poletaeva 1955, 1960) and subsequently from the Wuliuan of the Kuznetsk Alatau (Repina 1969). Only cranidia are known for the species, and these have a typical morphology of Acadoparadoxides cranidia. Consequently,
E. suboelandicus cannot be grouped under Eccaparadoxides with any certainty.

In summary, a number of species from the Altay-Sayan Foldbelt that have been assigned to Eccaparadoxides must be regarded as doubtful members of this genus or as not assignable to Eccaparadoxides. Some are taxonomically unrecognisable.

Table 1 summarizes the suggested taxonomy of all species so far assigned to Eccaparadoxides.

\section{Conclusions on taxonomy, morphology and phylogeny of Eccaparadoxides}

\section{Taxonomy}

Paradoxides sensu lato is a prime example of taxonomic problems that can result from the subdivision of a wellknown, broadly defined genus into more tightly defined genera and/or subgenera based on locally distinctive species. Šnajdr's (1957) subgenera are largely based on Bohemian species. In the present-day concepts of these genera or subgenera with numerous additional species included these type species lie distinctly eccentric in the morphological ranges so that these species are often not typical for the genera's or subgenera's morphology. Nomenclatural stability, however, requires definition of genera and subgenera of the Paradoxides s.l. clade by reference to Šnajdr's and to subsequent genus definitions.

Based on the existing nomenclatural studies, Eccaparadoxides must be defined primarily on the basis of the morphology of Paradoxides pusillus Barrande, 1846. The diagnostic characters of this species feature the following: a fairly slender glabella (with respect to the maximum width of the cranidium); distinctly marked glabellar furrows S3 and S4; long, thin to moderately broad (tr.) and distinctly arcuate palpebral lobes extending into relatively transversely directed eye ridges; an anterior border with moderate curvature medially that extends into relatively weakly curved, slightly abaxially expanding lateral sectors; a facial suture intersecting the anterior border adaxial to the most abaxial position of the palpebral lobe's centre; a pygidium with a subhexagonal outline, posterior margin slightly indented; axis with only one well-defined axial ring, length less than half of the pygidial length; pleural furrows absent.

\section{Morphology}

Given the morphological plasticity of the cranidial characters, particularly during ontogeny, few cephalic features allow discrimination of Eccaparadoxides from other taxa of 
the Paradoxides s.l. clade. Nevertheless, the length and curvature of the palpebral lobes and their continuation into the eye ridges; the relatively slender posterior of the glabella, the distinct glabellar furrows S3 and S4; and the adaxial position of the facial suture provide distinctive criteria for the cranidium of Eccaparadoxides. More readily recognisable is the pusillus-type pygidium with its elongated subhexagonal outline, a transverse posterior margin and a relatively short tapering axis with only one ring clearly marked. The same types of cranidia and pygidia are known from the coeval and partly co-occurring species $E$. rohanovicus, and, partly, from Mawddachites kozaki from Bohemia and E. zelus sp. nov. from the Delitzsch-Torgau-Doberlug Syncline, Germany, and E. epimetheus sp. nov. from the Anti-Atlas of Morocco. The Bohemian species oppanol is too incompletely known to be referred to Eccaparadoxides with certainty. These Perunican-West Gondwanan species must be regarded as the characteristic subclade of Eccaparadoxides.

The western Avalonian species Eccaparadoxides eteminicus, E. lamellatus and E. acadicus certainly represent species that form another "subclade" which is closely related to the Perunican-West Gondwanan species noted above. The western Avalonian species are primarily characterised by a lamellatus-type pygidium, which is slightly more elongate and has more closely spaced posterolateral corners than the pusillus-type pygidium.

Another morphological cluster of species is centred in Iberia and includes the Spanish species Eccaparadoxides sequeirosi and E. pradoanus and a species from Spain, Sardinia and the Montagne Noire commonly reported as $E$. mediterraneus (see remarks above), Other taxa include a species identified in Spain as E. acadicus and the Anatolian species E. remus. Although their cranidia frequently show a greater variation than that shown by the typical E. pusillustype cephala, these E. pradoanus-type species/forms are primarily characterised by a distinctly more longitudinally elongate outline of the pygidium with a consequently shorter pygidial axis and a progressive tendency to develop a slender posterior with a pair of short spines rather than simple corners. Eccaparadoxides marginatus from Anatolia lacks posterolateral spines, but has a bilobate posterior margin of the elongate pygidium. It possibly is a precursor of the forked posterior margins typical for the pradoanus group.

\section{Phylogeny}

Both the lamellatus and the pradoanus groups appear to evolve into species in which the pygidia have a lateral margin with a double curvature, which means the posterior end is developed has a sort of swallow-tail outline. A pygidium showing this feature is figured from the "forchhammeri Grits" of Shropshire, eastern Avalonia (Cobbold and Pocock 1934: pl. 42, fig. 9), but without a known cranidium this specimen provides little evidence for phylogeny. Hence, it remains an open question whether the development of this type of pgidium records parallel or convergent evolution as suggested by species from different palaeocontinents or whether it originated in the Mediterranean sector of West Gondwana. The stratigraphic distribution of the species and differences in cranidial features between both groups seems to indicate separate evolutionary lineages.

The core group of species with a swallow-tailed pygidium include Eccaparadoxides/Macrocerca melaguesensis from the Montagne Noire and a form identified as E. melaguesensis from Spain, a species earlier identified as E. brachyrachis (sic) from the Montagne Noire and macrocercus from the Montagne Noire. The latter species is particularly striking because of its very elongated posterior part of the spatulate pygidium; it is the type species of the subgenus Macrocerca. Although this species was likely derived from a species with the E. melaguesensis morphology, E. macrocercus has a pygidial morphology and a facial suture that differ in such distinctive characters from those of E. pusillus that it cannot be assigned to Eccaparadoxides based on the commonly accepted diagnostic concept of the genus. Consequently, Macrocerca should be raised from a subgenus to the genus level.

Two other species with a violin-shaped pygidium with a double curvature of its outline and short, swallow-tail end should be mentioned. One is Eccaparadoxides freboldi from southeastern Newfoundland, which also has a similarly late, but probably only upper Drumian occurrence (see remarks above) as macrocercus. Eccaparadoxides freboldi, however, could be derived from an E. lamellatus-type species.

The second is a species/form from Bornholm represented by a similar pygidium with a swallow-tail posterior margin separated by curved lateral margins and an axis with at least two recognisable rings and ca. half the pygidial length. This species was erroneously described by Brøgger (1878) from the Oslo region, Norway and by Grönwall (1902) as "Paradoxides rugulosus" (see Dies Álvarez et al. 2010: figs. 2C, 2J). As emphasised by Dies Álvarez et al. (2010), the pygidia of this Scandinavian species/form closely resemble those of Eccaparadoxides mediterraneus as known from Spain, but their cranidia can be relatively easily distinguished.

Given the fact that the species from the lower Amgan of the Siberian Platform assigned to Eccaparadoxides are not true species of Eccaparadoxides, the oldest species of the genus are represented by two morphological groups. In Iberia, the species E. asturianus, E. sdzuyi and E. sulcatus are of Wuliuan age. All are characterised by a pygidium with a subcircular outline, an axis of slightly more than half the pygidial length and with a tendency to have more than one well-defined axial ring. The somewhat younger species E. rouville $i$ appears to belong as well to this clade. Specimens from the Iberian Chains and the Montagne 
Noire seem to show slight morphological differences, but these may be a result of imperfect preservation. In any case, the differences in pygidial and cranidial morphology with $E$. pusillus strongly suggest that these species cannot be assigned to Eccaparadoxides, and it is suggested to unite them as a new subgenus under Acadoparadoxides. Given the imperfect knowledge of E. asturianus, E. sdzuyi and $E$. sulcatus, we refrain from proposing this subgenus. Provisionally, this group is considered as an early plexus of Eccaparadoxides.

Species from the Wuliuan of Scandinavia with a pygidium with posteriorly expanding, subtriangular outline and spines on the posterior margin have been united by Šnajdr (1986) as the subgenus Baltoparadoxides under Acadoparadoxides-a reasonable proposal that appears to reflect the phylogenetic development in the region. These species would then include oelandicus, quadrimucronatus, and bidentatus. A possible additional species of Baltoparadoxides was described as $P$. immanis from coeval strata of the Olenek Uplift of the Siberian Platform.

The index species for the traditional lowermost "Middle Cambrian" in Scandinavia has been assigned to Eccaparadoxides as E.? insularis, which would make it the oldest known species of the genus globally. Its cranidium has relatively short anterior branches of the facial suture and fairly well defined lateral glabellar furrows S3 and S4, although not as deeply impressed as in typical species of Eccaparadoxides. The palpebral lobes, however, are more reminiscent of those in Acadoparadoxides. The pygidium has a short axis and a suboval outline with a slightly clipped posterior margin-more reminiscent to the pusillus-type species of Eccaparadoxides, but not typical for the genus. We therefore regard its generic assignment to Eccaparadoxides as provisional. Acadoparadoxides? pinus, the index fossil of the overlying biozone in Scandinavia, is not so different in its morphology and could be a morphologically distinct descendant of oelandicus. However, this species certainly cannot be assigned to Eccaparadoxides despite its short anterior branches of the facial suture. Another species from the pinus Biozone of Scandinavia was described as Eccaparadoxides? thorslundi (Rushton et al. 2016). Its morphology does not allow an unequivocal generic assignment, but it may be derived from an oelandicus-type ancestor and is a precursor of the pusillus-type plexus.

The genus Rejkocephalus Kordule, 1990, restricted to Bohemia/Perunica, is likely derived from species of the pusillus group. The genus includes two species, the type species $R$. rotundatus (Barrande, 1846) and R. knizeki Kordule, 1990, with a fairly different pygidial morphology. However, both are characterised by a similar cephalic morphology. The most striking features in the cranidium are the short palpebral lobes, which clearly differentiates them from the cranidia of Eccaparadoxides. The pygidial morphology is characterised by a broader overall shape and small, closely located posterior spines, which appears to indicate a simple morphologic/allometric gradient from E. pusillus-type predecessors. However, more important is the presence of several, posteriorly directed pleural ribs and additional axial rings. Specimens of Rejkocephalus knizeki appear to indicate the pathway for the addition of segments: incomplete fusion of axial rings in this species suggests that the morphology is generally a result of the fusion of the posterior thoracic segment with a E. pusillus-type pygidium (Fig. 5).

\section{Systematic palaeontology}

The specimens used for this study and listed below are in repository of the Bundesanstalt für Geowissenschaften und Rohstoffe, Außenstelle Geowissenschaftliche Sammlungen, Berlin-Spandau (GSB); the Mineralogisches Museum der Universität Würzburg (MMUW); the Národní Muzeum v Praze, Prague (NM); and the collection of Patrick Bommel (BOM).

Family Paradoxididae Emmrich, 1839

Subfamily Paradoxidinae Emmrich, 1839

Genus Eccaparadoxides Šnajdr, 1957

Type species. Paradoxides pusillus Barrande, 1846, from the Jince Formation, Bohemia, Czech Republic.

Discussion. This report has discussed existing taxonomic problems of the genus Eccaparadoxides. As outlined above, a majority of the species partly or occasionally assigned to Eccaparadoxides have a questionable generic assignment. However, the remaining species reflect at least four different morphological groups, termed the pusillus, lamellatus, pradoanus and asturianus groups. The systematic significance of these groups is difficult to assess based on the available data. In this report they are tentatively assigned to Eccaparadoxides, although the asturianus and pradoanus groups appear to be better placed outside Eccaparadoxides.

Eccaparadoxides zelus sp. nov.

Figures 6, 7, 8, 9

pars 1928 Paradoxides pusillus_Picard: 26. pars 1931 Paradoxides pusillus_-Picard and Gothan: 135. 1944 Paradoxides pusillus BARR.-Schmidt: 357, pl. 23, fig. 13.

1944 Paradoxides rugulosus CORDA-Schmidt: $358-360$, pl. 21, figs. 21-26, pl. 22, fig. 1-10.

1957 Paradoxides aff. rugulosus CORDA 1847-Sdzuy: 11-12, fig. 1. 

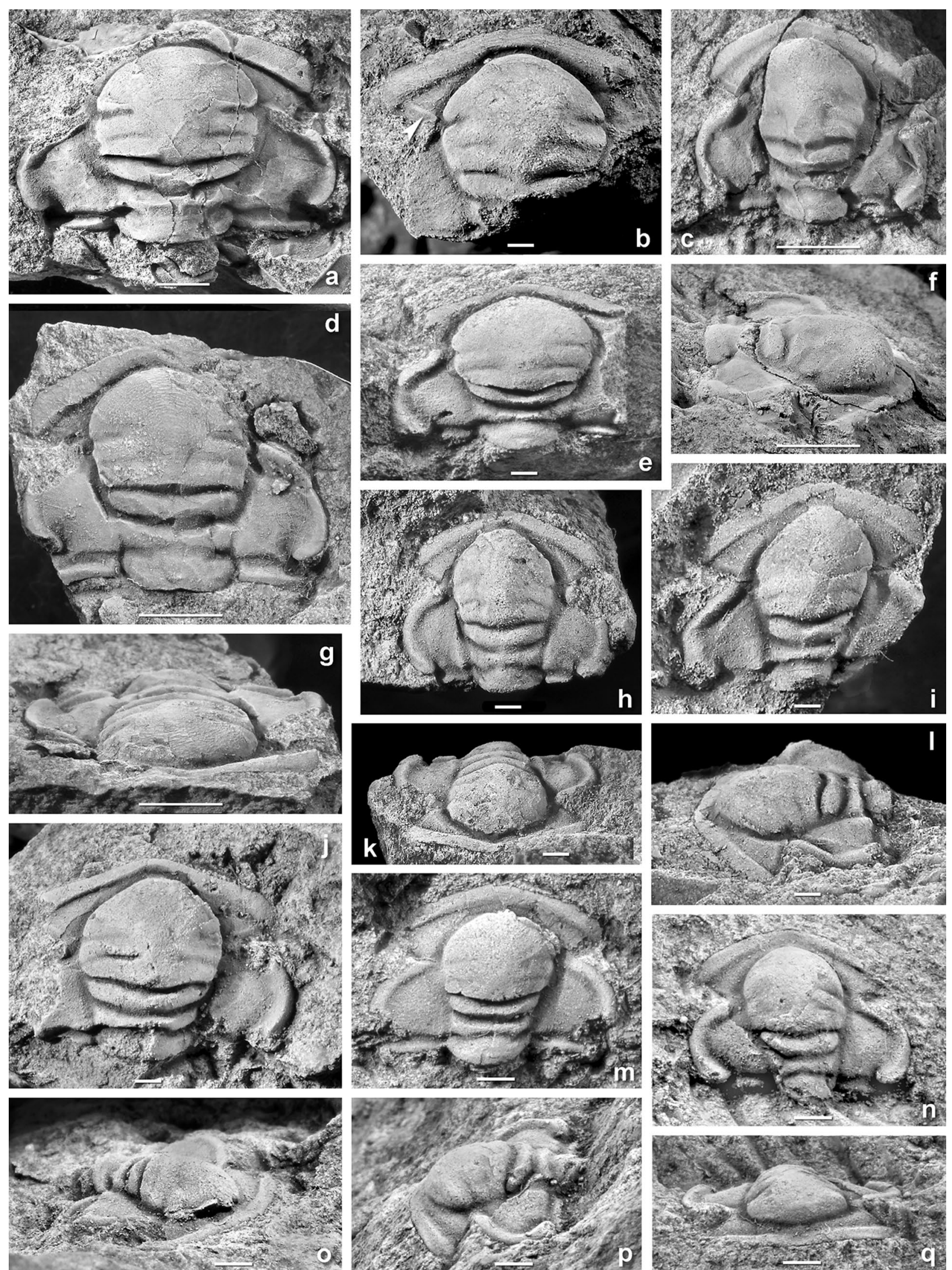
४Fig. 6 Eccaparadoxides zelus sp. nov. a GSB X4717, holotype, incomplete cranidium, from 195 m; b GSB X4716/1, paratype, partial cranidium showing funnel-shaped lateral terminations of $\mathrm{S} 4$, from uncertain depth; c, f GSB X4714, paratype, incomplete cranidium, dorsal and lateral views, from uncertain depth; d, g GSB X4713, paratype, incomplete cranidium, dorsal and anterior views, from uncertain depth; e GSB X4719, paratype, incomplete cranidium, from uncertain depth; h, k GSB X4715, paratype, incomplete cranidium, dorsal and oblique anterior views, from $186 \mathrm{~m}$; i, l GSB X4716/2, paratype, incomplete cranidium, dorsal and lateral views, from uncertain depth; j, o GSB X4718, paratype, incomplete cranidium, anterior and oblique anterolateral views, from $184 \mathrm{~m}$; m, p GSB X4720, paratype, incomplete cranidium, dorsal and lateral views, from $186 \mathrm{~m}$; $\mathbf{n}$, q GSB X4757/2, paratype, incomplete cranidium, dorsal and anterior views, from $190 \mathrm{~m}$. Dorsal views if not otherwise noted. All specimens from Delitzsch Formation, Badulesia tenera Biozone, drillcore Doberlug IV/1929, northwest of Kirchhain, Delitzsch-TorgauDoberlug Syncline, northern Saxony, Germany. All scale bars $1 \mathrm{~mm}$

Etymology. Named for the Greek Z $\tilde{\eta} \lambda$ os, literally "zeal"; in Greek mythology the personification of dedication, emulation, eager rivalry and jealousy.

Holotype. GSB X4717, cranidium (Fig. 6a) (Schmidt 1944: pl. 21, fig. 26a, 26b; with counterpart).

Type locality. Doberlug IV/1929 drill site, northwest of Kirchhain, Delitzsch-Torgau-Doberlug Syncline, Northern Saxony, Germany.

Type stratum. Delitzsch Formation, Badulesia tenera Zone, Wuliuan-Drumian boundary interval, Miaolingian Series. From 195 m depth in the core (see Geyer and Malinky 2019: fig. 2).

Paratypes. Incomplete cephalon under GSB X12995 (from uncertain depth); 60 cranidia under GSB X4712 (Schmidt 1944: pl. 21, fig. 21; uncertain depth), GSB X4713 (Schmidt 1944: pl. 21, fig. 22; uncertain depth), GSB X4714 (Schmidt 1944: pl. 21, fig. 23a, 23b; uncertain depth), GSB X4715 (Schmidt 1944: pl. 21, fig. 24; from 186 m), GSB X4716/1 (Schmidt 1944: pl. 21, fig. 25; uncertain depth), GSB $\mathrm{X} 4716 / 2$ (on the same piece as GSB X4716/1; uncertain depth), GSB X4718 (Schmidt 1944: pl. 22, fig. 1; from 184 m), GSB X4719 (Schmidt 1944: pl. 22, fig. 2; uncertain depth), GSB X4720 (Schmidt 1944: pl. 22, fig. 3; from 186 m), GSB X4757b (from 190 m), GSB X06239/7 (from 186 m), GSB X06246/2 (from 187 m), GSB X12948/2 (uncertain depth), GSB X12950 (uncertain depth), GSB X12951 (uncertain depth), GSB X12952/1 (uncertain depth), GSB X12952/2 (uncertain depth), GSB X12953/1 (uncertain depth), GSB X12954 (uncertain depth), GSB X12955 (uncertain depth), GSB X12956 (from 190 m), GSB X12958 (from 195 m), GSB X12960 (uncertain depth), GSB X12961/1 (uncertain depth), GSB X12962 (uncertain depth), GSB X12963 (from 195 m), GSB X12964 (from 178 m),
GSB X12965 (from 195 m), GSB X12967 (from 179 m), GSB X12968 (from 185 m), GSB X12969 (uncertain depth), GSB X12970 (from 198 m), GSB X12971 (from 189 m), GSB X12972 (uncertain depth), GSB X12973 (from 197 m), GSB X12976 (from 196 m), GSB X12979/2 (from 179 m), GSB X12980/1 (from 186 m), GSB X12980/2 (from 186 m), GSB X12981/1 (uncertain depth), GSB X12981/2 (uncertain depth), GSB X12982/2 (from 195 m), GSB X12982/3 (from 195 m), GSB X12983 (uncertain depth), GSB X12986 (from 195 m), GSB X12987 (uncertain depth), GSB X12989 (from 186 m), GSB X12990 (external mould, uncertain depth), GSB X12999/1 (uncertain depth), GSB X12999/2 (uncertain depth), GSB X12999/3 (uncertain depth); cranidium with attached librigena under GSB X12961/2 (uncertain depth); two incomplete cephala with attached hypostome under GSB X12957 (uncertain depth) and GSB X12959 (from $194 \mathrm{~m}$ ); three nearly complete dorsal exoskeletons under GSB X12948/1 (uncertain depth), GSB X12974 (from 197 m) and GSB X12979/1 (from 197 m); enrolled specimen with most of the thorax covered in the matrix, with ventral side of cephalon with attached rostral plate and hypostome as well as posterior part of the thorax and pygidium exposed, GSB X4721 (part and counterpart; Schmidt 1944: pl. 22, fig. 4; uncertain depth); cranidium with attached partial thorax under GSB X12999/4 (uncertain depth); incomplete, partly detached thoraces under GSB X4724 (Schmidt 1944: pl. 22, fig. 7; uncertain depth), GSB X12991 (from $186 \mathrm{~m}$ ) and GSB X12994 (uncertain depth); incomplete thorax with articulated pygidium under GSB X06251/2 (uncertain depth), GSB X4722 (Schmidt 1944: pl. 22, fig. 5; from $194 \mathrm{~m}$ ), GSB X12966 (uncertain depth); isolated thoracic segments under GSB X12982/1 (from 195 m), GSB X12992 (from $180 \mathrm{~m}$ ) and GSB X12993 (from $184 \mathrm{~m}$ ); five isolated librigenae under GSB X12947 (from 186 m), GSB X12991/2 (from 190 m), GSB X12982/4 (from 195 m), GSB X12982/5 (from 195 m), GSB X12984 (from 178 m); nine isolated hypostomata, GSB X4726 (Schmidt 1944: pl. 22, fig. 9a-c; from 195 m), GSB X4727 (Schmidt 1944: pl. 22, fig. 10a, 10b; from 195 m), GSB X12968 (from 197 m), GSB X12975 (from 186 m), GSB X12977 (uncertain depth), GSB X12978 (uncertain depth), GSB X12985 (uncertain depth), GSB X12997 (from 197 m), GSB X12998/2 (from $195 \mathrm{~m}$ ); two pygidia with three thoracic segments attached, GSB X4723 (Schmidt 1944: pl. 22, fig. 6; from 186 m), GSB X4724 (Schmidt 1944: pl. 22, fig. 7; uncertain depth); three isolated pygidia under GSB X4725 (external mould; Schmidt 1944: pl. 22, fig. 8; from 190 m), GSB X12949/2 (from 189 m), GSB X12966/L (uncertain depth). All specimens from Doberlug IV/1929 core, northwest of Kirchhain, Delitzsch-Torgau-Doberlug Syncline, northern Saxony, Germany, middle Cambrian. The specimens figured by Schmidt (1944) were originally in the collection of the Geologisches Landesmuseum of the Reichsamt 

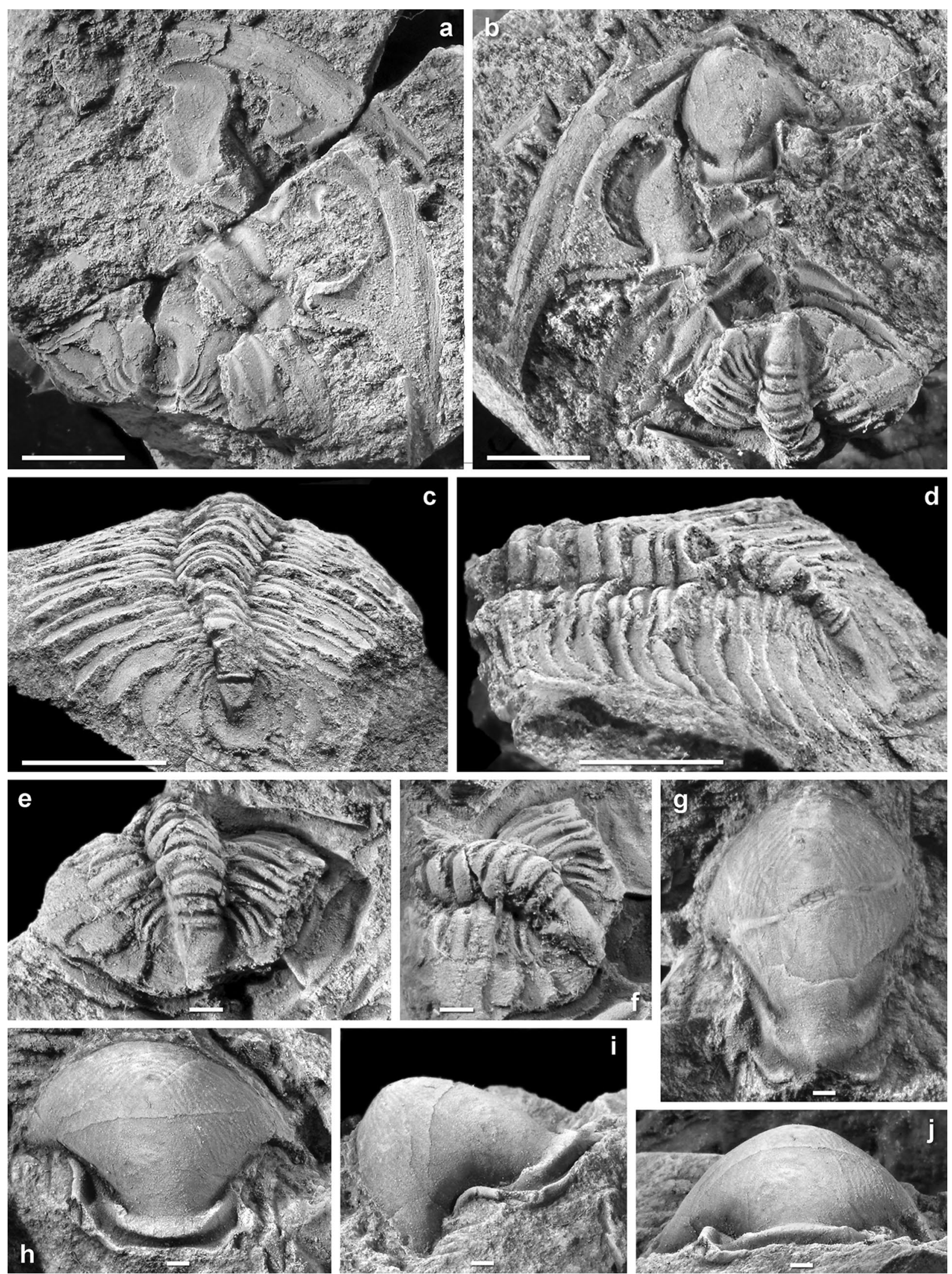
4Fig. 7 Eccaparadoxides zelus sp. nov. a, b, e, f GSB X4721, paratype, incomplete exoskeleton, part (in a) and counterpart (in b) of incompletely enrolled specimen showing overturned posterior thorax and pygidium, entire specimen $(\mathbf{a}, \mathbf{b})$ and detail of posterior thorax and pygidium in dorsal and oblique lateral views $(\mathbf{e}, \mathbf{f})$, from uncertain depth; c, f GSB X4722, incomplete dorsal carapace with inclined posterior thorax and pygidium, oblique posterior and oblique lateral views, from $194 \mathrm{~m}$; g GSB X4727, paratype, hypostome, from 195 m; h, i, j GSB X4726, paratype, hypostome, dorsal, lateral and posterior views, from $195 \mathrm{~m}$. Dorsal views if not otherwise noted. All specimens from Delitzsch Formation, Badulesia tenera Biozone, drill-core Doberlug IV/1929, northwest of Kirchhain, Delitzsch-Torgau-Doberlug Syncline, northern Saxony, Germany. Scale bars $1 \mathrm{~mm}$ except in $\mathbf{a}-\mathbf{d}(=5 \mathrm{~mm})$

für Bodenforschung, Berlin, under Schmidt's numbers or under provisional numbers. The specimens were transferred to the Zentrales Geologisches Probenarchiv of the German Democratic Republic and are now in the collections of the Bundesanstalt für Geowissenschaften und Rohstoffe, Außenstelle Geowissenschaftliche Sammlungen, in Berlin-Spandau (GSB) under the listed collection numbers.

Diagnosis. Species of Eccaparadoxides with glabella pyriform, posteriorly relatively slender, slightly expanding forward; frontal lobe subevenly rounded or with slightly less curved anterolateral margins; S3 distinct, slightly shallower than S4, terminates distant from axial furrow; S4 relatively short, distinctly incised, with funnel-shaped lateral termination in dorsal view; palpebral lobes strongly arcuate, anterior and posterior tips slightly thickened, posterior tips located roughly at level of occipital furrow, anterior tips at mid-L4 or slightly posterior to S4; eye-ridges with slight anterior curvature; anterior border moderately wide (sag. and exsag.), evenly curved around sagittal line, anterolateral parts almost straight, slightly expanding abaxially; anterior branches of facial suture intersect anterior border at most distal level of palpebral lobe or at level of palpebral furrow; pygidium with elongate subhexagonal outline, with rounded lateral corners or more or less evenly curved lateral margin, posterior median sector with distinct indentation; pygidial axis slightly more than half of pygidial length, with one fairly well-defined axial ring; lateral margin slightly raised at anterolateral corners, progressively weakly defined posteriorly; without recognisable pleural ribs. (Diagnosis for adult individuals.)

Description of adult morphology. Glabella moderately convex in transverse profile, ca. 92-95\% cephalic length (including occipital ring), pyriform with slight anterior expansion in its posterior part. Four pairs of lateral glabellar furrows, S1 and S2 deeply incised and transglabellar, S3 and S4 less distinct but recognisable. S1 slightly posteriorly directed from near lateral margin of glabella and slightly curved. S2 transversely directed in its lateral portions, slightly posteriorly directed across the sagittal sector; S3 not continuous medially, its abaxial ends terminate well before the lateral margins of the glabella, faintly convex forward and slightly oblique to axis, generally slightly less distinct than S4; S4 fairly short and not continuous medially, wellincised on internal moulds, less so on the exterior of the cuticle, extend abaxially to the axial furrow often with a short funnel-shaped end (Fig. 6a, b), slightly oblique to the axis. Frontal lobe with anterior margin mostly with uniform curvature in dorsal view, but lateral sections sometimes with lower curvature; max. tr. width of anterior part of glabella lobe ca. 46-55\% max. cranidial width across centre of palpebral lobes (ratio increases with sclerite size) and ca. $130-165 \%$ of width across occipital ring (generally decreasing with sclerite size). Occipital ring with gently curved posterior margin, but with low curvature medially across sag. line; max. sag. length ca. 16-20\% cephalic length, width ca. $31-38 \%$ cranidial width across centre of palpebral lobes; with moderate sag. convexity and medial node located slightly posterior to the centre. Occipital furrow composed of a shallow median section which curves slightly forward and with distinct lateral sections almost normal to axis.

Palpebral lobe strongly arcuate, exsag. of ca. $42-49 \%$ max. cephalic length (generally slightly decreasing with increased size), well elevated, (sub)evenly convex in tr. section, its centre in adult individuals opposite middle part of L2 at axial furrow, anterior end of ocular suture opposite origin of S4 at axial furrow or faintly posterior to it, posterior end opposite anterior part of occipital ring; with nearly uniform width throughout except for slightly broadened posterior tips. Palpebral lobe confluent with eye ridge without distinct angulation, but with distinct change in direction. Eye ridge nearly straight or slightly sigmoidal, oriented oblique towards anterior from intersection with palpebral lobe, generally tapering and less convex in anterior half, fades at anterolateral corners of frontal lobe.

Intraocular genae ca. 19-23\% max. cranidial width across centre of palpebral lobes and ca. 36-46\% max. cephalic length (exsag.) adjacent to axial furrow; with slightly elevated, longitudinally oval bacculae in the posteroadaxial part.

Preglabellar field absent or in small specimens developed as very narrow strip confluent with anterior border furrow. Preocular areas irregularly triangular with low ridge parallel to the facial suture (arrow in Fig. 6b).

Anterior branches of facial suture straight, directed obliquely forward from anterior ends of ocular suture, curving distinctly adaxially from about posterior third of anterior border; abaxial tips of anterior border located approximately at exsag. level of centre of palpebral furrow. Posterior branches moderately long, directed steeply abaxially from posterior ends of palpebral lobes, adaxial part nearly straight, abaxial section with a slight curvature. 

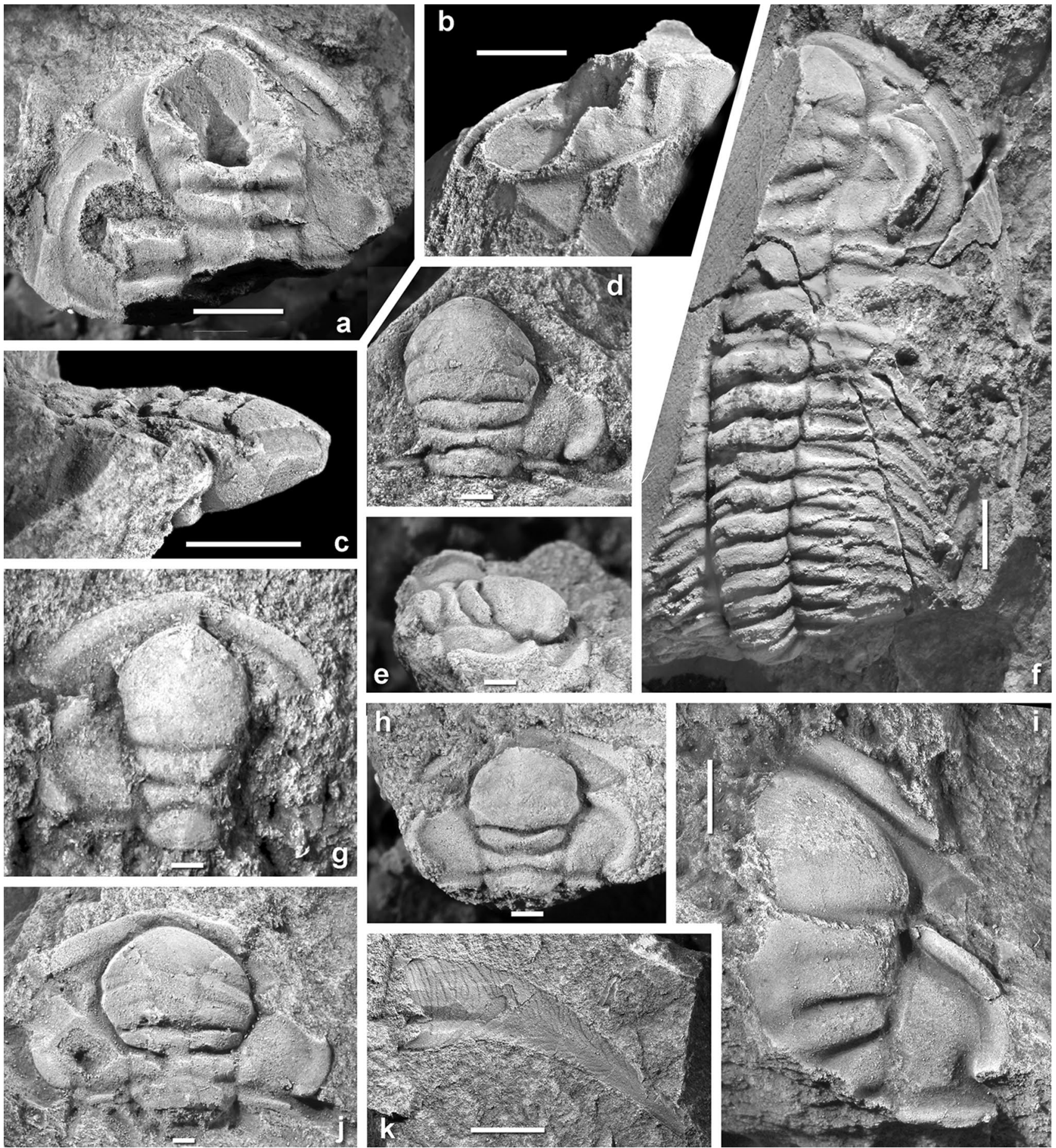

Fig. 8 Eccaparadoxides zelus sp. nov. a, b GSB X12957, paratype, incomplete cephalon with semi-attached hypostome preserved as external mould, dorsal and oblique lateral views showing slightly inclined position of hypostome in respect to the cranidium, from uncertain depth; c GSB X12959, paratype, incomplete cephalon with attached hypostome, lateral view, from uncertain depth; d, e GSB $\mathrm{X} 12952 / 2$, paratype, partial cranidium, dorsal and oblique lateral views, from uncertain depth; f GSB X12948/1, paratype, partial dorsal exoskeleton with partially enrolled posterior part of thorax, from uncertain depth; g GSB X12969, incomplete cranidium, from uncer- tain depth; h GSB X12953/1, paratype, partial cranidium, dorsal and oblique lateral views, from uncertain depth; i GSB X12973, paratype, partial cranidium, paratype, from uncertain depth; j GSB X12999/1, incomplete cranidium, from uncertain depth; k GSB X4757/4, thoracic pleura, external mould of ventral side showing herring-bone pattern of terrace ridges, from $190 \mathrm{~m}$. Dorsal views if not otherwise noted. All specimens from Delitzsch Formation, Badulesia tenera Biozone, drill-core Doberlug IV/1929, northwest of Kirchhain, Delitzsch-Torgau-Doberlug Syncline, northern Saxony, Germany. Scale bars $1 \mathrm{~mm}$ except in $\mathbf{f}(=5 \mathrm{~mm})$ 
Anterior border elevated, central portion of anterior margin with moderate curvature, anterolateral parts of anterior margin nearly straight, posterior margin of anterior border more strongly posteriorly directed so that it expands slightly in exsag. width; surface with low convexity (sag., exsag.) (Fig. 6o, p).

Posterior border relatively narrow (exsag.), slight expansion in width toward facial suture, moderately elevated, almost straight or slightly sigmoidal in dorsal view. Posterior border furrow moderately deep on internal moulds, less impressed on exterior of cuticle, moderately broad throughout its course on cranidium.

Librigena with fairly narrow ocular platform. Lateral border moderately broad (tr.), subequal in width for most of its exsag. expansion, but widen posteriorly, moderately elevated in tr. profile and with nearly flat surface in its central (tr.) part, grades into a long, moderately thick, continuously and evenly tapering genal spine of gentle curvature, its base moderately wide, without a change in curvature of the lateral margin. Posterior border not entirely preserved in any of the available specimens, apparently narrow. Ventral doublure of lateral genal border and genal spine covered with coarse, roughly subparallel terrace ridges (Fig. 7b).

Rostral plate known from one exoskeleton, a simple plate with anterior and posterior margins running subparallel to each other and to the anterior cephalic border, with more pronounced curvature in sag. and exsag. profile; covered with fine, subparallel terrace ridges (Fig. 7b).

Hypostome with oval middle body and subrectangular posterior unit framed by lateral and posterior borders; sagittal length about two-thirds maximum width. Posterior border transverse medially; abaxially it trends obliquely laterally and anteriorly and curves into moderately long marginal spine projecting from lateral border and directed obliquely abaxially. Lateral border almost exsagittally directed.

Middle body a very convex anterior lobe of ca. $85 \%$ hypostomal length on sag. line; lateral parts of anterior lobe distinctly extended dorsally (Fig. 7i), covered by terrace lines more-or-less paralleling plate relief and forming longitudinally oval whorl. Posterior lobe of middle body semilunate, distinctly convex in sag. and exsag. profile, laterally separated from anterior body by distinct oblique furrows. Maculae not recognised.

Thorax known from three more-or-less complete specimens and several disarticulated segments. With at least 16 segments. Segments of generally similar shape, but successive posterior decrease in size, with decreasing pleural length (tr.), width of axial rings (tr.) and an increasing posterior orientation of pleural spines. Axial ring widest at segment 1 where it is slightly narrower than $30 \%$ width of entire segment, rings successively narrow to segment 16 , to a width slightly less than half the width of axial ring of segment 1 and slightly less than 40\% width of segment 16 . Axial rings with nearly straight anterior and slightly concave posterior margin and slightly constricted medially. Lateral portions with faint swellings near axial furrows, indicating attachment sites of ventral muscles. Articulating half-ring moderately wide (sag., exsag.).

Thoracic pleurae divided by a moderately deep, welldeveloped pleural furrow which starts adaxially near anterolateral corners of axial ring and runs slightly oblique to axis to end at approximately two-thirds the exsag. width in adaxial third of the pleural spines. Boundary between pleural spine and adaxial part of pleura marked by minute triangular fulcral process at anterior margin and corresponding notchlike indentation at posterior margin (Fig. 9n). Pleural spines elongate, moderately posteriorly curved in anterior half of thorax. Pleural spine progressively lengthens relative to segment size and curves posteriorly and broadens in segments ca. 9-16. Posterior segments 14-16 have blade-like, overlapping pleural spines that frame the pygidium laterally (e.g., Fig. 7c, e). Tips of pleural spines in segment 16 approximately at the level of the posterior pygidial tips.

Pygidium longitudinally suboval, maximum transverse width near midlength, ca. 80-85\% sagittal pygidial width; lateral margin nearly uniformly curved in anterior two-thirds, slightly less curved in the posterior third. Posterior margin moderately wide (tr.), slightly concave in dorsal view. Axis subtriangular in outline, with rounded posterior margin, rests on indistinctly defined socle, axis of slightly more than half the pygidial length; only one axial ring distinctly defined by straight furrow, remaining part of axis with indistinct, shallow median impression at about midlength; with welldefined, narrow (sag.) articulating half-ring. Pleural fields apparently smooth, with low longitudinally directed ridge near axis in anterior sector. No pygidial border and border furrow developed for most part, but border developed as a low, poorly defined lobe anterolaterally. Ventral doublure of pygidium very broad, covered with relatively coarse terrace ridges.

Exterior of cuticle either smooth or covered with minute granules. Anterior border and lateral cephalic border with terrace ridges parallel to the anterior, lateral and posterior margins.

Discussion. Eccaparadoxides zelus sp. nov. is closely related to $E$. pusillus, the type species of the genus. Single cranidia of the two species with similar preservation cannot be distinguished with any certainty although minor differences exist in the tendency of E. zelus to have weakly expanded anterior and posterior tips of the palpebral lobes and curved eye ridges. The frontal glabellar lobe in E. zelus sp. Nov. is fairly slender, i.e. it has a low ratio of sag. length vs. max. tr. width at $\mathrm{S} 4$. This ratio is lower than in most other similar species (e.g., E. pusillus, E. rohanovicus or E. epimetheus sp. nov.). 

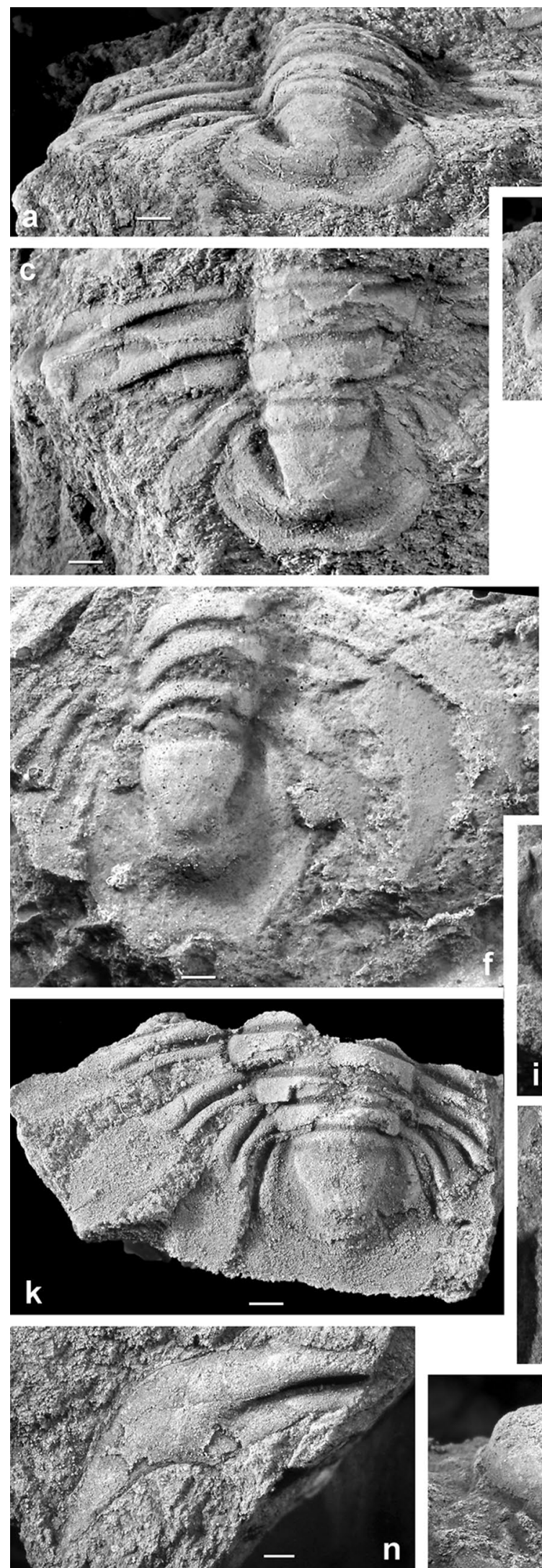
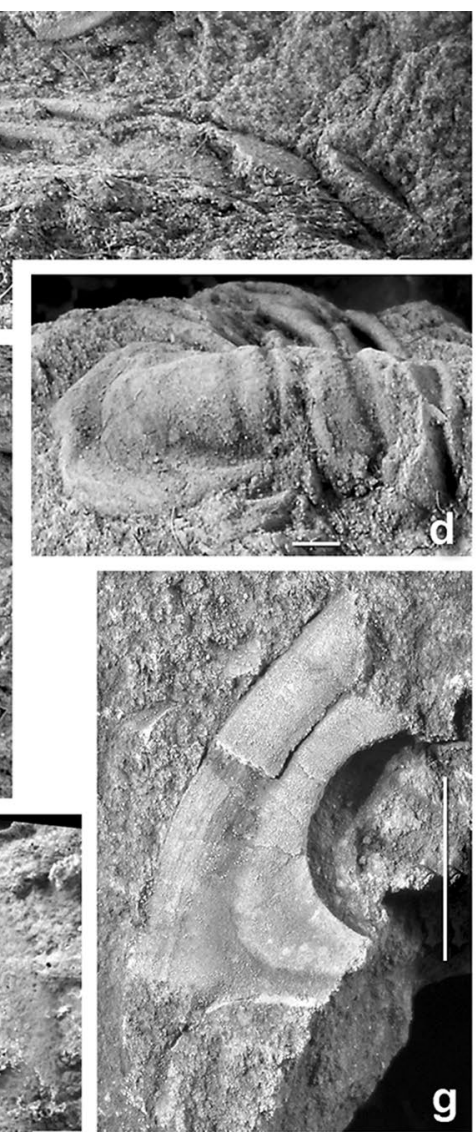

g
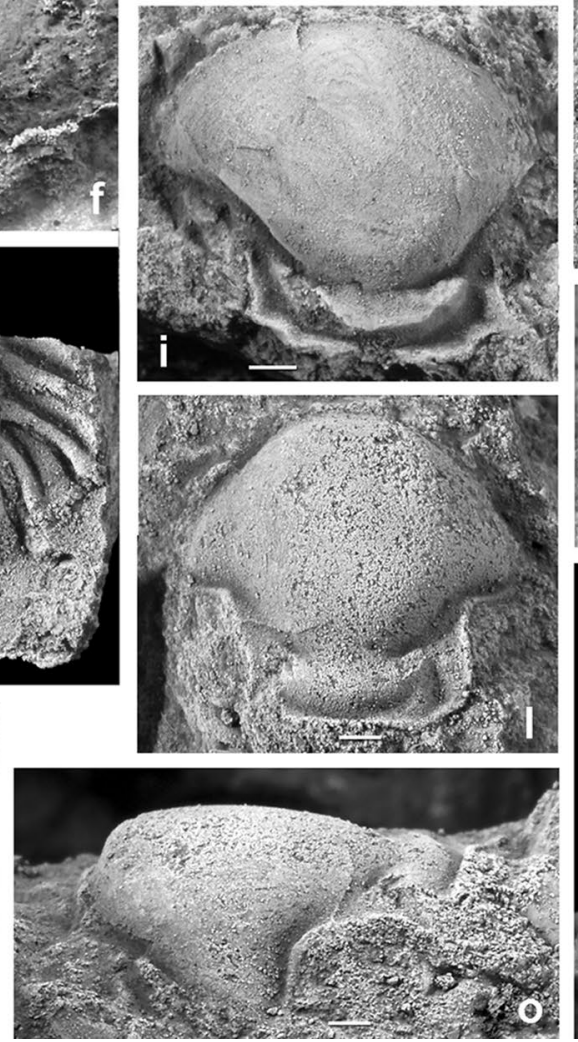
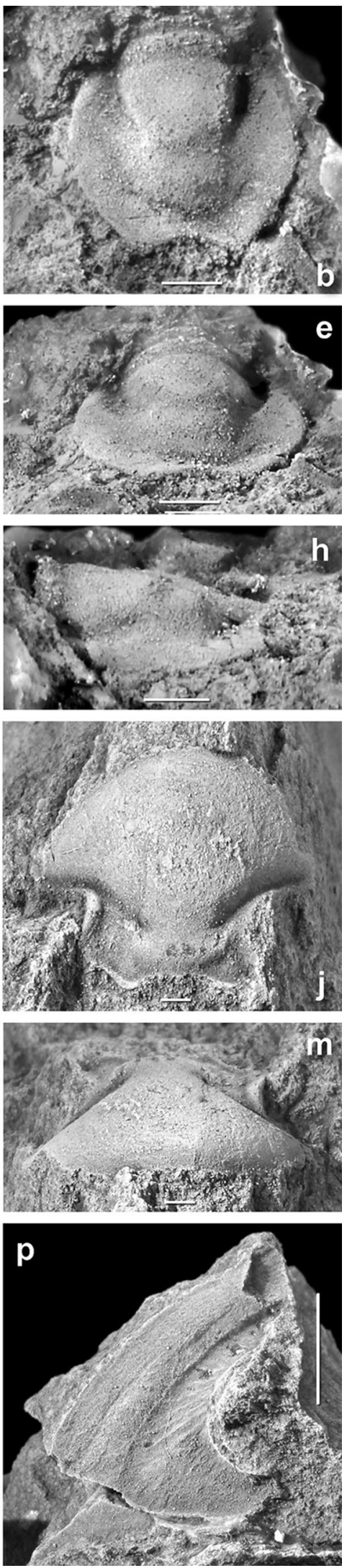
४Fig. 9 Eccaparadoxides zelus sp. nov. a, c, d GSB X4723, paratype, semiattached posterior thoracic segments and pygidium, oblique posterior, dorsal and lateral views, from $186 \mathrm{~m}$; b, e, h GSB X4725, paratype, pygidium, latex cast of external mould, dorsal, oblique posterior and lateral views, from $190 \mathrm{~m}$; f GSB X4724, paratype, posterior thorax and pygidium, latex cast of external mould, from uncertain depth; g GSB X12982/5, paratype, librigena, dorsal view, from 195 m; i GSB X4726, paratype, hypostome, from 195 m; j, m GSB X12975, paratype, hypostome, from 186 m; k GSB X12966, paratype, hypostome, from uncertain depth; l, o GSB X12977, paratype, hypostome, dorsal and lateral views, from uncertain depth; n GSB X12992, paratype, thoracic pleura, from 180 m; p GSB X12954, paratype, incomplete librigena with caeca on pleural field, latex cast, from uncertain depth. Dorsal views if not otherwise noted. All specimens from Delitzsch Formation, Badulesia tenera Biozone, drill-core Doberlug IV/1929, northwest of Kirchhain, Delitzsch-Torgau-Doberlug Syncline, northern Saxony, Germany. Scale bars $1 \mathrm{~mm}$ except in $\mathbf{g}(=5 \mathrm{~mm})$

The pygidium differs from that of Eccaparadoxides pusil$l u$ s. It has an elongate subhexagonal outline with usually almost uniformly curved lateral margins or faint, rounded lateral corners, and the posterior median sector shows a distinct indentation. In addition, the pygidial axis is usually slightly more than half the pygidial length. The pygidium of E. pusillus, in contrast, has fairly well-marked lateral corners and a shallow indentation of the posterior margin; its axis is clearly shorter than half the pygidial length. The pygidium of E. rohanovicus has rounded lateral corners or curved lateral margins as in E. zelus sp. nov., but the posterior margin is almost straight, and its axis is also clearly shorter than half the pygidial length.

Remarks. Three specimens in the material are articulated, enrolled exoskeletons and thoraxes with attached pygidia. This suggest that the enrolled condition frequently occurred among the specimens embedded as entire and semicomplete individuals and that these animals were enrolled and rapidly buried alive by sediment. The mode of enrolment is comparable to that reported from other paradoxidine species (e.g., Esteve 2013; Geyer and Vincent 2015; Laibl et al. 2016). Loose enrolment includes specimens in which the thorax is slightly convex in lateral aspect, with the segments only slightly inclined against each other but with a stronger inclination in the posterior third of the thorax. The pygidium forms an inclined flap together with the three posterior segments (Fig. 7b, c, d); these segments and the pygidium then acted as a structural unit. Eccaparadoxides zelus sp. nov. was probably also capable of tight enrolment, as known in E. pradoanus (e.g., Esteve 2013: fig. 8E), with the pygidium resting below the cephalon. One specimen from the Doberlug IV drillhole (Fig. 7a, b) shows nearly complete, tight enrolment with the posterior thorax and pygidium underneath the anterior part of the thorax, whereas the cephalon lies slightly anterior to it.
Eccaparadoxides epimetheus sp. nov.

Figures 10, 11

1985 Paradoxides (Eccaparadoxides) sp.—Destombes et al.: 167.

2006 Paradoxides (Eccaparadoxides) sp.-Geyer and Landing: 107.

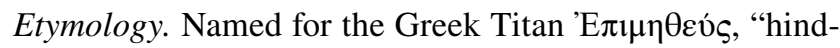
sight", or literally "afterthinker"; in Greek mythology the brother of Prometheus and the son of Iapetus.

Holotype. MMUW 2021-I-028, incomplete dorsal exoskeleton (Fig. 10h, k).

Type locality. Hassi Brahim section, north of the road from Tata to the Issafen area and $5 \mathrm{~km}$ WSW of Tata (Lambert coordinates $240 / 304,29^{\circ} 38^{\prime} 30^{\prime \prime} \mathrm{N}, 8^{\circ} 22^{\prime} 30^{\prime \prime} \mathrm{W}$ ), geological map sheet Akka-Tafagount-Tata 1: 200,000), southern flank of western Anti-Atlas, Morocco.

Type stratum. Level represented by sample HRG, Jbel Wawrmast Formation, Badulesia tenera Zone, Wuliuan-Drumian boundary interval, Miaolingian Series.

Paratypes. Incomplete cephalon under GSB X12995 (from uncertain depth); 60 cranidia. All specimens from Hassi Brahim area, mostly from the Hassi Brahim section (HBR-, with most sample horizons given in metres above base of measured section), southern margin of western Anti-Atlas. From sample HBR-D1887 (ca. $290 \mathrm{~m}$ above the base): incomplete dorsal exoskeleton under MMUW 2021-I-013; nine cranidia (often incomplete) under MMUW 2021-I-002, -003, -004, $-006,-008,-010,-011,-012$ and -014; fragmentary cephalon under MMUW 2021-I-005; hypostome under MMUW 2021-I-001; pygidium under MMUW 2021-I-007. From sample HBR-250.5: single cranidium under MMUW 2021I-015. From sample HBR-316.5: cranidium under MMUW 2021-I-018; two hypostomata under MMUW 2021-I-016 and -017. From section slightly lateral of the HBR main section, sample HRG: three cranidia under MMUW 2021I-026, -027, -029, two hypostomata under MMUW 2021I-025 and -030. From sample HRG-A: five cranidia under MMUW 2021-I-019, -021, -032,-033 and -035, hypostome under MMUW 2021-I-020. From sample HRG-B: hypostome under MMUW 2021-I-0222. From sample HRG-F: cranidium under MMUW 2021-I-023; pygidium under MMUW 2021-I-024. From sample HRG-U: two cranidia under MMUW 2021-I-031 and -032.

Diagnosis. Species of Eccaparadoxides with pyriform glabella, posterior part moderately slender, slightly expanding forward; frontal lobe almost uniformly rounded or with 

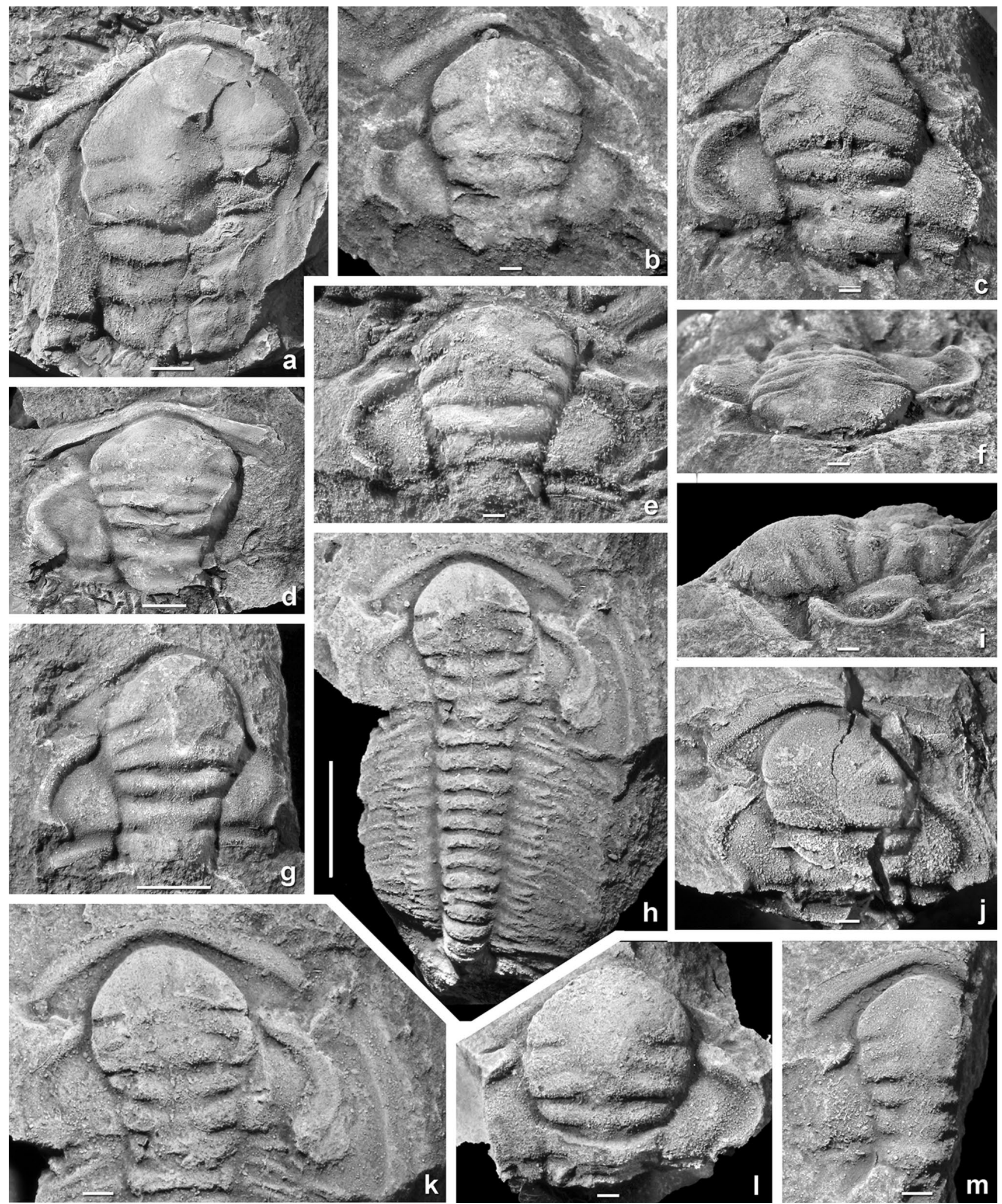

slightly less curved anterolateral margins; S3 well-marked, terminates distant from axial furrow; $\mathrm{S} 4$ relatively short, but distinctly incised, with funnel-shaped lateral termination in dorsal view; palpebral lobes strongly arcuate, nearly uniform in tr. width, posterior tips located roughly at level of occipital furrow, anterior tips at mid-L4 or S4; eye-ridges straight, slightly oblique to axis; anterior border thin to moderately wide (sag. and exsag.), uniformly curved around sag. line, 
४Fig. 10 Eccaparadoxides epimetheus sp. nov. a MMUW 2021-I-008, paratype, partial cranidium, from sample HBR-D1887; b MMUW 2021-I-021, paratype, incomplete cranidium, from sample HRG-A; c, f, i MMUW 2021-I-006, paratype, incomplete cranidium, dorsal, anterior and left lateral views, from sample HBR-D1887; d MMUW 2021-I-010, paratype, partial cranidium, from sample HBR-D1887; e MMUW 2021-I-018, paratype, partial cranidium, from sample HBR316.5; g MMUW 2021-I-011, paratype, incomplete cranidium, from sample HBR-D1887; h, k MMUW 2021-I-028, holotype, incomplete dorsal exoskeleton, dorsal view of entire specimen and detail of cephalon with slightly detached librigena, from sample HRG; j MMUW 2021-I-015, paratype, incomplete cranidium, from sample HBR250.5; I MMUW 2021-I-012, paratype, partial cranidium, from sample HBR-D1887; m MMUW 2021-I-029, paratype, partial cranidium, from sample HRG. Dorsal views if not otherwise noted. All specimens from (extended) Jbel Wawrmast Formation, Badulesia tenera Biozone, Hassi Brahim section, southern slope of western Anti-Atlas, Morocco. Scale bars $1 \mathrm{~mm}$, except $\mathbf{a}, \mathbf{g}, \mathbf{h}(=5 \mathrm{~mm})$

anterolateral portions almost straight, slightly expanding abaxially; anterior branches of facial suture intersect anterior border at level of centre of palpebral lobe or at level of palpebral furrow; pygidium with roughly subovate outline, posterolateral angles moderately rounded, posterior median sector with low curvature, without posterolateral corners; pygidial axis subtriangular, more than half the pygidial length, with one fairly well-defined axial ring; lateral margin slightly raised at anterolateral corners, progressively poorly defined posteriorly; one or sometimes two steeply posteriorly directed, low pleural ribs developed adjacent to anterior half of axis. (Diagnosis for adult individuals.)

Description of adult morphology. Glabella moderately convex in tr. profile, $92-95 \%$ cephalic length (including occipital ring), pyriform, slightly expanding forward in posterior part. Four pairs of lateral glabellar furrows, S1 and S2 deeply incised and transglabellar, S3 and S4 less distinctive but well-defined. S1 slightly posteriorly directed from lateral margins of glabella and slightly curved. S2 transversely directed laterally, with a slight posterior curvature across central part; S3 interrupted medially, its abaxial ends terminate distant to lateral margins of the glabella, weakly convex forward and slightly oblique to axis, generally slightly less distinct than S4; S4 fairly short and broadly interrupted medially, extends abaxially to axial furrow and sometimes with a short funnel shape in dorsal view (Fig. 10b, m), slightly oblique to axis. Frontal lobe with outline of a segment of a circle, anterior margin mostly with uniform curvature in dorsal view, lateral sections sometimes with lower curvature; max. tr. width of anterior part of glabella ca. 48-55\% max. cranidial width across centre of palpebral lobes (increases with sclerite size) and ca. 135-160\% width across occipital ring. Occipital ring with gently curved posterior margin, with low curvature medially across sag. line; max. sag. length ca. $13-18 \%$ cephalic length, width ca. $30-37 \%$ cranidial width across centre of palpebral lobes; with moderate sag. convexity and with median node. Occipital furrow composed of shallow median section, which curves slightly forward and with distinctive lateral sections almost normal to axis.

Palpebral lobe arcuate, exsag. ca. 42-54\% max. cephalic length (generally slightly lower in large sclerites), distinctly elevated, almost uniformly convex in tr. section, but occasionally divided into two lobes by a faint subcentral depression (Fig. 10k); centre in adult individuals opposite S1 or middle of L2 at axial furrow, anterior end of ocular suture opposite origin of S4 at axial furrow or slightly posterior to it, posterior end opposite anterior part of occipital ring or occipital furrow, posterior ends always slightly more distant from axis than anterior ends; with nearly uniform width throughout except for slightly broadened posterior tips. Palpebral lobe confluent with eye ridge without distinct angulation to it, but with distinct change in direction. Eye ridge nearly straight or with slightly sigmoidal, directed obliquely anteriorly from its connection with palpebral lobe, generally tapering and less convex in its anterior half, fading at anterolateral corners of frontal lobe.

Intraocular genae ca. 20-24\% max. cranidial width across centre of palpebral lobes and ca. 36-43\% max. cephalic length (exsag.) adjacent to axial furrow; with distinct, slightly elevated, longitudinally oval bacculae in the posteroadaxial part.

Preglabellar field absent or developed as a very narrow strip confluent with anterior border furrow in small specimens. Preocular areas irregularly subtrapezoidal, with a low ridge parallel to facial suture.

Anterior branches of facial suture directed obliquely anterolaterally from origin at anterior ends of ocular suture, with straight section up to distinct adaxial curve at about posterior third of anterior border; abaxial tips of anterior border located approximately opposite the max. abaxial location of palpebral furrow or opposite adaxial half of palpebral lobes. Posterior branches short to moderately long, directed steeply abaxially from posterior ends of palpebral lobes.

Anterior border elevated, with moderate curvature of anterior margin in central sector, anterolateral parts of anterior margin nearly straight, posterior margin of anterior border more strongly posteriorly directed so that it widens slightly exsag.; surface with low convexity (sag., exsag.).

Posterior border relatively narrow (exsag.), relatively uniform in exsag. width or slightly widens toward facial suture, moderately elevated, almost straight or slightly sigmoidal in dorsal view. Posterior border furrow moderately deep on internal moulds, moderately broad throughout its course on the cranidium.

Librigena with fairly narrow ocular platform. Lateral border moderately broad (tr.), relatively uniform in width, but slight increases in width posteriorly, grades into a long, 

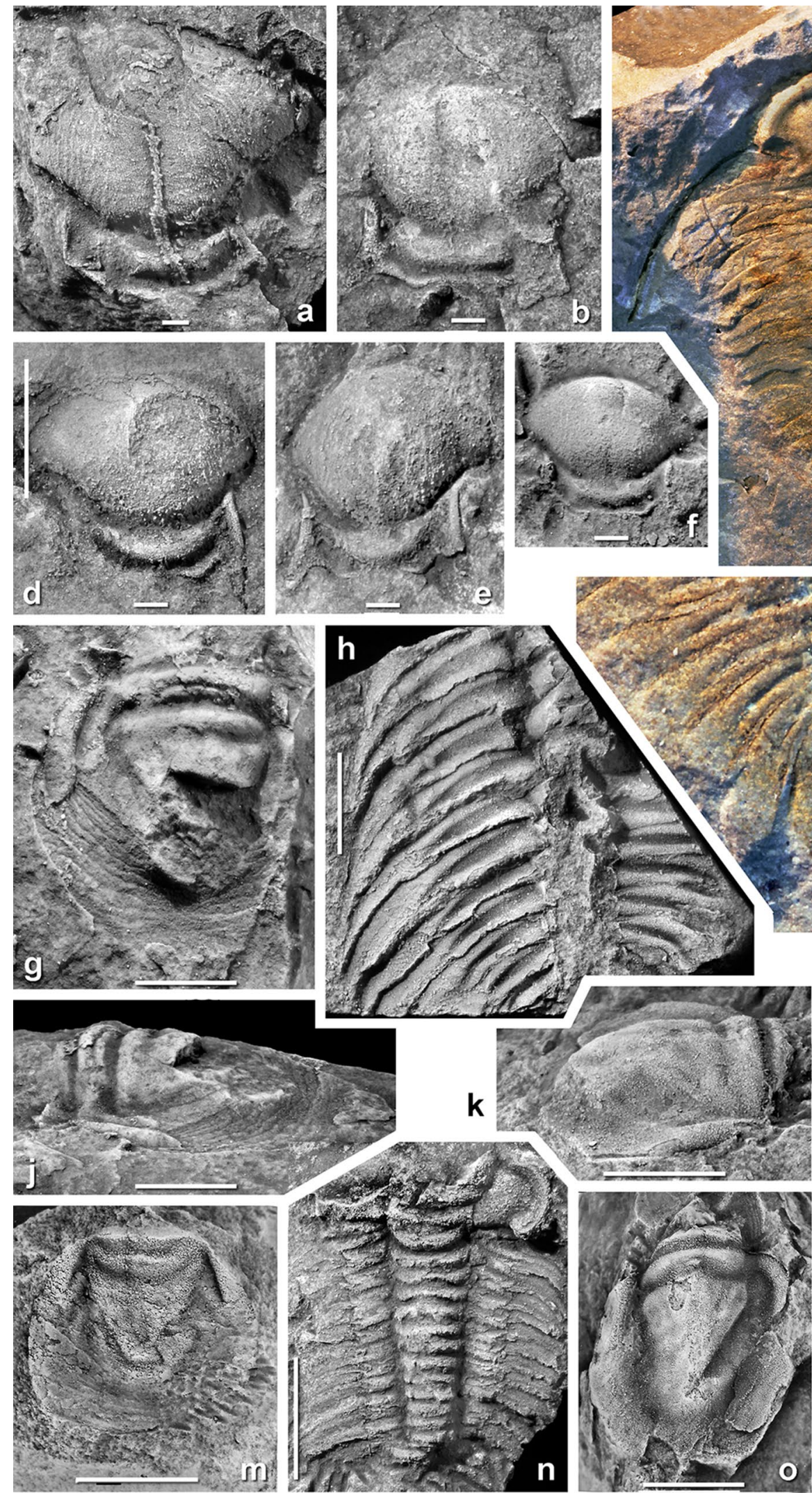

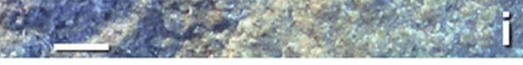
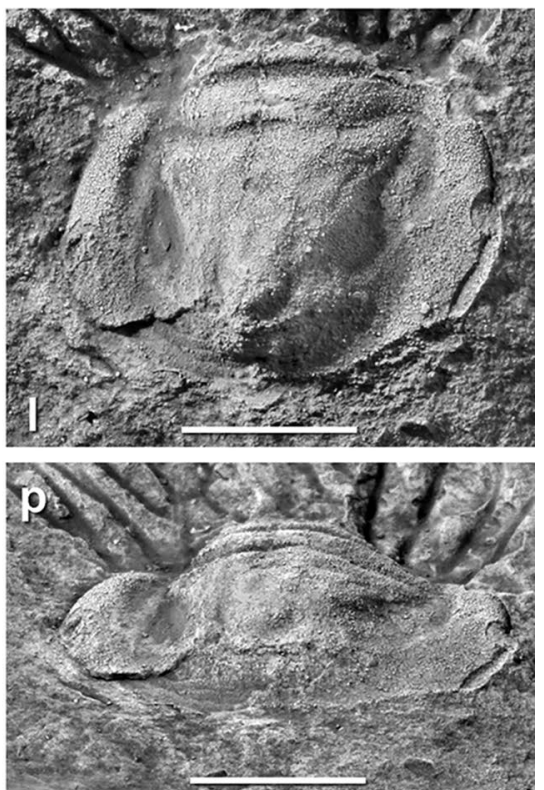
४Fig. 11 Eccaparadoxides epimetheus sp. nov. a MMUW 2021-I016, paratype, hypostome, from sample HBR-316.5; b MMUW 2021-I-025, paratype, hypostome, from sample HRG; c, i BOM 2728, paratype, nearly complete dorsal exoskeleton, entire specimen and enlarged view of posterior thorax and pygidium, from unknown sample horizon; d MMUW 2021-I-017, paratype, hypostome, from sample HBR-316.5; e MMUW 2021-I-030, paratype, hypostome, from sample HRG; f MMUW 2021-I-020, paratype, hypostome, from sample HRG-A; g, j MMUW 2021-I-024, paratype, partial pygidium with exposed doublure, from sample HRG-F; h MMUW 2021-I-009, paratype, incomplete dorsal carapace, detail of thorax showing articulating devices and distribution of terrace ridges, from sample HBR-D 1887; k, I, p MMUW 2021-I-007, paratype, incomplete pygidium, oblique lateral, dorsal and oblique posterior views, from sample HBR-D 1887; m MMUW 2021-I-043, paratype, pygidium, from sample HBR-D 1887; n MMUW 2021-I-013, paratype, partial dorsal exoskeleton, from sample HBR-D 1887; o MMUW 2021-I-041, paratype, pygidium, from sample HBR-D 1887. Dorsal views if not otherwise noted. All specimens from (extended) Jbel Wawrmast Formation, Badulesia tenera Biozone, Hassi Brahim section, southern slope of western Anti-Atlas, Morocco. Scale bars $1 \mathrm{~mm}$, except $\mathbf{c}, \mathbf{h}$, $\mathbf{n}(=5 \mathrm{~mm})$

moderately thick, evenly tapering, gently curved genal spine, its base moderately wide without a change in curvature of the lateral margin; tips of genal spines located ca. onethird of body length from posterior end. Posterior border fairly narrow. Ventral doublure of lateral genal border and genal spine covered with coarse, roughly subparallel terrace ridges.

Rostral plate unknown.

Hypostome with oval middle body and subrectangular posterior part framed by lateral and posterior borders; sag. length about two-thirds of the max. width. Posterior border is transverse medially, but indented; abaxially it trends obliquely abaxially and forward and curves into a moderately long marginal spine extending from the lateral border with variable curvature.

Middle body of hypostome consists of strongly convex anterior lobe with ca. 80-85\% length of hypostome on sag. line; lateral parts of anterior lobe distinctly dorsally extended (in anatomical position), covered by terrace lines more-orless parallel to hypostome relief (Fig. 11a). Posterior lobe of middle body semilunate, distinctly convex in sag. and exsag. profile, defined from the anterior body laterally by distinct oblique furrows. Maculae not recognised.

Thorax known from four more-or-less complete specimens and several disarticulated segments, consisting of at least 16 segments. Segments generally of comparable morphology, but with anterior to posterior decrease in overall size with a decrease in pleural length (tr.) relative to pleural width (exsag.), a drecrease in width of axial rings (tr.) and increasing posterior orientation of pleural spines. Axial ring widest at segment 1 where it is slightly more than one-quarter width of segment, rings successively narrow to segment 16 where ring has a tr. width of slightly less than half of the axial ring at segment 1 and ca. $40 \%$ tr. width of segment
16. Axial rings with nearly straight anterior margin, slightly concave posterior margin, and thus weakly constricted medially. Lateral parts near axial furrows faintly swollen, indicating attachment sites of ventrally located muscles. Articulating half-ring moderately wide (sag. and exsag.).

Thoracic pleurae divided by moderately deep, welldeveloped pleural furrow, which starts adaxially near anterolateral corners of axial ring and runs oblique to axis to end at slightly more than half exsag. width and in adaxial third of the pleural spines. Boundary of pleural spine and adaxial part of pleura marked by triangular fulcral process at anterior margin and corresponding notch-like indentation at posterior margin. Pleural spines more or less falcate, moderately posteriorly curved in anterior half of the thorax. Pleural spine progressively lengthens relative to segment size and curves posteriorly to develop into broader spines in segments ca. 11-16. Posterior segments $14-16$ have bladelike, overlapping pleural spines that envelop the pygidium laterally. Tips of pleural spines in segment 16 approximately opposite posterior pygidial tips (Fig. 11i).

Pygidium longitudinally suboval, max. tr. width near midlength, ca. $80 \%$ sag. pygidial width; lateral margin nearly uniformly curved. Posterior margin moderately wide (tr.), slightly concave in dorsal view. Axis subtriangular in outline, with rounded posterior margin, rests on weakly defined socle, approximately half the pygidial length. One axial ring defined by straight, deep furrow, a second one faint; articulating half-ring well-defined, narrow (sag.). Pleural fields apparently smooth with low longitudinally directed ridge near axis in the anterior half (Fig. 111, m), a second one sometimes faintly indicated (Fig. $11 \mathrm{~m}$ ). No pygidial border and border furrow developed for most part, but border developed as a low and weakly defined lobe anterolaterally. Ventral doublure of pygidium very broad, covered with relatively coarse terrace ridges (Fig. 11g, j, 1, m).

Exterior of cuticle apparently smooth. Anterior border and lateral cephalic border with terrace ridges parallel to anterior, lateral and posterior margins; anterior portion of middle body of hypostome with Bertillon pattern.

Discussion. Eccaparadoxides epimetheus sp. nov. has a cranidium typical of Eccaparadoxides, with a glabella with slightly diverging lateral margins posteriorly, a relatively short frontal lobe and well-impressed lateral glabellar furrows S3 and S4, the latter with apparently funnel-shaped lateral ends in dorsal view. The palpebral lobes are strongly arcuate; the anterior border is relatively narrow (sag.), with a moderate curvature on the sag. line, extending into weakly expanding lateral branches towards the facial suture, and it has a relatively flat dorsal surface. These features are typical of species of Eccaparadoxides of the pusillus and lamellatus groups. Specific cranidial characters of E. epimetheus sp. 
nov. are the prominent palpebral lobes and the moderately broad (tr.), rather than slender, glabella.

The species is best recognised by its pygidial characters. The pygidium has a more-or-less subovate outline where the posterolateral angles are gently rounded so that the median sector of the posterior margin has a low convex curvature rather than a slight indentation as in almost all other species of the pusillus and lamellatus groups and in species assigned to Eccaparadoxides in general. One or sometimes two steeply posteriorly directed pleural ribs occur close to the anterior half of the axis, which is quite unusual for Eccaparadoxides species. A similar type of pygidial morphology is known from Mawddachites kozaki, from roughly coeval strata in Bohemia. The latter species is clearly differentiated from E. epimetheus sp. nov. in having a more subtrapezoidal outline of the pygidium and a shorter pygidial axis. Its cranidium has less elevated palpebral lobes. It has a peculiar anterior border, which is very narrow on the sagittal line and strongly bent backward, and forms distinctly curved anterolateral sections with concave sectors of the anterolateral margin. The subcircular to ovate pygidial outlines of the asturianus group resemble that of E. epimetheus, but this is a superficial similarity. The course of the anterolateral margin in the asturianus group species is always oblique abaxially, whereas the axis tends to be shorter and more strongly tapering, subtriangular. In addition, the palpebral lobes are less arcuate and the anterior cephalic border tends to be broader and more uniformly curved.

\section{Eccaparadoxides? hestia sp. nov.}

Figures 12, 13

Derivation of name. Name after Hestia ('E $\sigma \tau i \alpha$ ), an ancient Greek goddess associated with then-traditional virtues, including modesty; the name is an allusion to the relatively modest size and morphologically subtle features of sclerites of the species.

Holotype. MMUW 2021-I-036, dorsal exoskeleton, preserved as part and counterpart (Fig. 12).

Type locality. Lemdad Syncline, section Le V, High Atlas, Morocco, $30^{\circ} 48^{\prime} 20^{\prime \prime} \mathrm{N}, 8^{\circ} 14^{\prime} 45^{\prime \prime} \mathrm{W}$.

Type stratum. Jbel Wawrmast Formation, Kymataspis arenosa Zone, upper Agdzian/Wuliuan, Miaolingian Series/ Middle Cambrian (see Geyer et al. 1995: figs. 11, 14).

Paratypes. All specimens from Jbel Wawrmast Formation, Kymataspis arenosa Zone, Lemdad Syncline, western High Atlas, Morocco. From section Le I, sample horizon 1-7 (7 $\mathrm{m}$ above base of the measured section): MMUW 2021I-056 (exoskeleton, mould of ventral side with hypostome),
-048, -057 (two cranidia), -055 (hypostome); sample 1-9 (9 $\mathrm{m}$ above base of the measured section): MMUW 2021I-060 (enrolled specimen, ventral side), -061 (incomplete dorsal carapace), -062 (cranidium), -059 (thoracic pleura); samples 1-12 (12 $\mathrm{m}$ above base of the measured section): MMUW 2021-I-058; samples 1-12.5 (12.5 m above base of the measured section): MMUW 2021-I-065, -066 (pygidia); from section Le IV, samples 1-10 (10 m above base of the measured section): MMUW 2021-I-050 (hypostome with rostrum); section Le VIII, sample 1: MMUW 2021-I-051 (partial dorsal exoskeleton); from section Le XI, sample 1-north: MMUW 2021-I-052 (cranidium); section Le XV, sample 1-25 (ca. $25 \mathrm{~m}$ above base of the measured section): MMUW 2021-I-043, -044 (two cranidia), samples 1-30 (ca. $30 \mathrm{~m}$ above base of the measured section): MMUW 2021I-042 (single cranidium), sample 1-st: MMUW 2021-I-045 (incomplete dorsal carapace), -046 (cranidium); section Le XVI, samples 1-11: MMUW 2021-I-047 (cranidium); locality X61: MMUW 2021-I-037, -038 (two cranidia); locality X64: MMUW 2021-I-039 (incomplete dorsal exoskeleton); locality X76: MMUW 2021-I-040 (incomplete cranidium); locality X203: MMUW 2021-I-041 (incomplete cranidium). See Geyer et al. 1995: figs. 11, 14 and Geyer and Landing 2006: fig. 23 and 28 for $\operatorname{logs}$ and sample locations.

Material in repository tentatively assigned to Eccaparadoxides? hestia sp. nov. All specimens from, Jbel Wawrmast Formation, Kymataspis arenosa Zone, Lemdad Syncline, western High Atlas, Morocco. From section Le I, sample horizon 1-12.5: MMUW 2021-I-063 and -064 (two pygidia), from section Le IV, sample horizon 1-7: MMUW-I-049 (cranidium).

Diagnosis. Species tentatively assigned to Eccaparadoxides with pyriform glabella, posterior part relatively broad, slightly expands anteriorly; frontal lobe with uniformly curved anterior margin; S3 and S4 moderately deep; palpebral lobes moderately arcuate, relatively thick (tr.) on the exterior of the cuticle, posterior tips opposite occipital furrow, anterior tips opposite $\mathrm{S} 4$ or slightly posterior to it; eye ridges almost transverse; anterior border moderately wide (sag. and exsag.), evenly curved around sagittal line, anterolaterally gently curved to almost straight, slightly expanding abaxially; anterior branches of facial suture intersect anterior border at level of centre of palpebral lobe; pygidium with elongate subovate outline, lateral margins with relatively low curvature, posterior median sector almost straight; pygidial axis slightly more than half pygidial length, posterior margin uniformly curved; without recognisable pleural ribs.

Description of adult morphology. Glabella moderately convex in tr.nsverse profile, ca. 87-93\% cephalic length (including occipital ring), pyriform, slightly anteriorly expanding in 

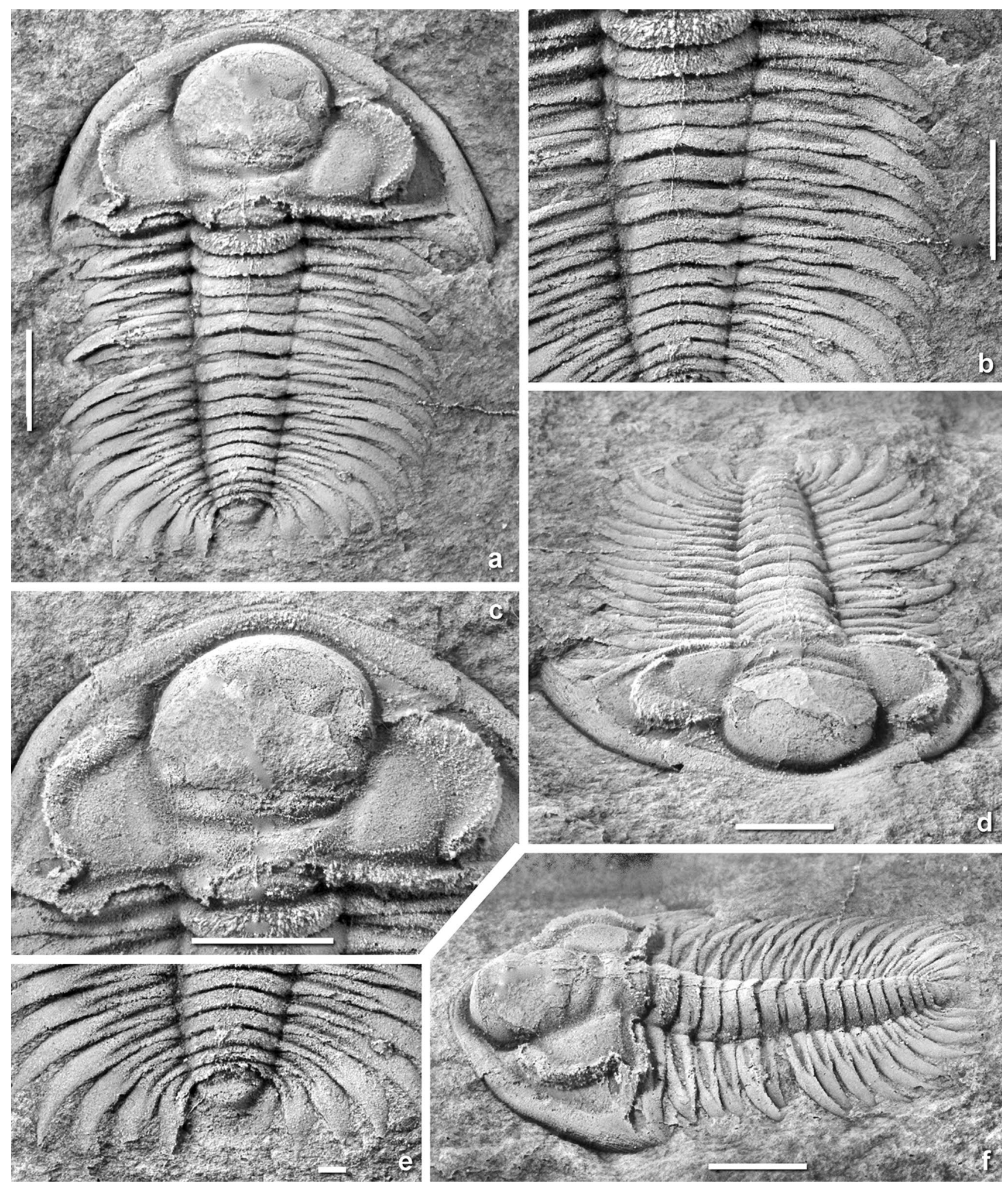

Fig. 12 Eccaparadoxides? hestia sp. nov. a-f MMUW 2021-I-037, dorsal exoskeleton, latex cast of counterpart; a dorsal view of entire specimen; b detail of thorax showing gradational change of pleural morphology; c close-up of cranidium; d oblique anterior view; e close-up of posterior thorax and slightly telescoped pygidium; $\mathbf{f}$ oblique lateral view of exoskeleton showing inclination of cranidium against anterior part of the thorax and slight concave curvature of median part of the thorax as an example of post-mortem configuration; from level ca. $25 \mathrm{~m}$ above the base of the Jbel Wawrmast Formation, Kymataspis arenosa Zone, Lemdad Syncline, section Le VI, western High Atlas, Morocco. Scale bars $5 \mathrm{~mm}$ except in e $(1 \mathrm{~mm})$ 


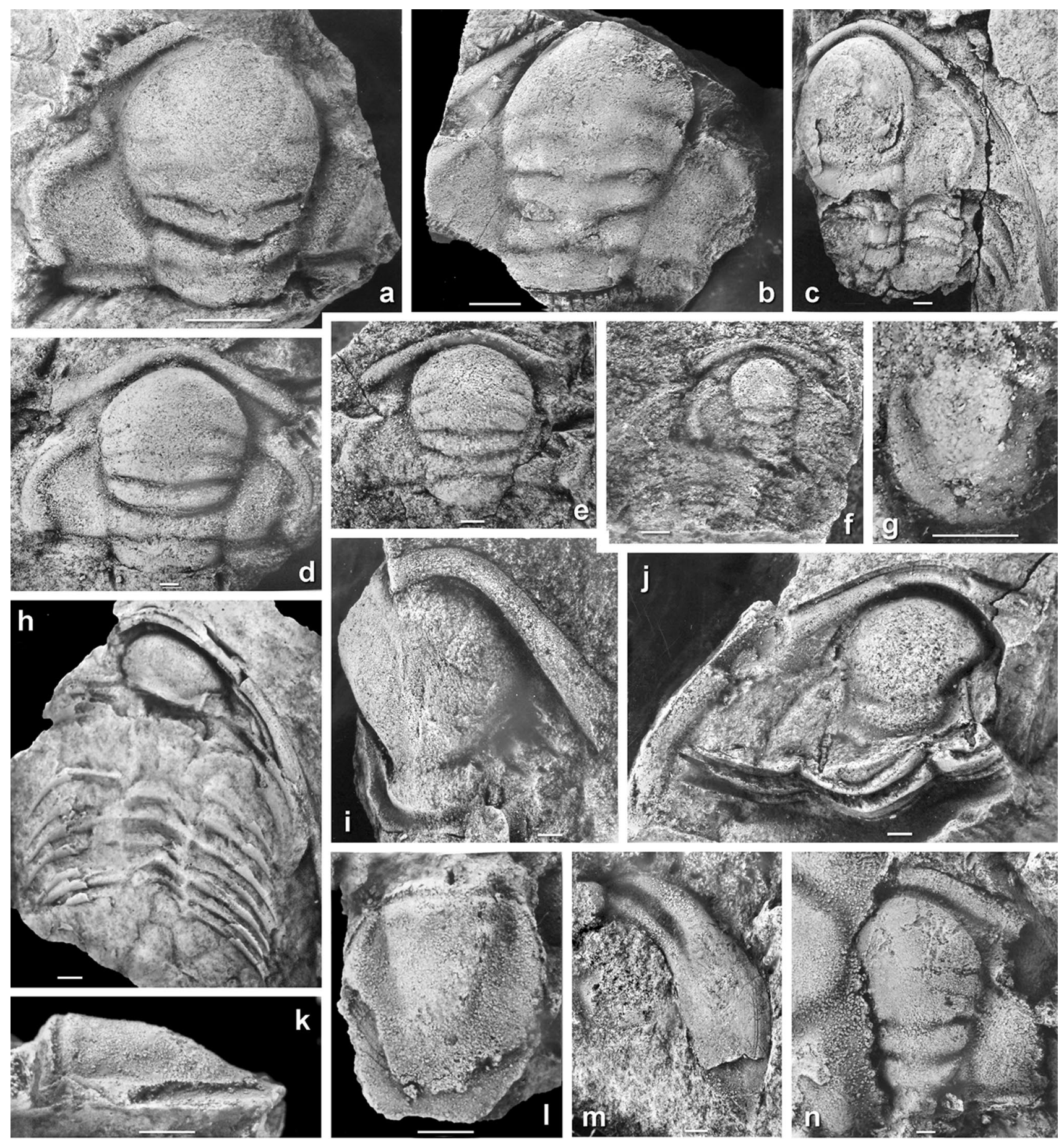

posterior part. Four pairs of lateral glabellar furrows, S1 and S2 well-developed and transglabellar, S3 and S4 less distinctive, often weakly developed. S1 slightly posteriorly directed near lateral margins of glabella and curved to mostly form a uniformly curved arc. S2 transversely directed laterally, with a slight posterior curvature across centre of glabella; S3 fades medially, its abaxial ends terminate well before lateral margins of glabella, oriented slightly oblique to axis; S4 fairly short and broadly interrupted medially, extends abaxially to or near to axial furrow, slightly oblique to axis. Frontal lobe with $\mathrm{r}$ anterior curvature, outline almost semicircular, anterior margin mostly with uniform curvature in dorsal view. Max. tr. width of anterior part of glabellar lobe ca. $50 \%$ of max. cranidial width across centre of palpebral lobes and ca. $135 \%$ (130-145\%) tr. width of occipital ring. Occipital ring with gently curved posterior margin; max. sag. length ca. 13-16\% cephalic length, width ca. 30-35\% of cranidial width across centre of palpebral lobes; with 
४Fig. 13 Eccaparadoxides? hestia sp. nov. a MMUW 2021-I-037, paratype, cranidium, sample locality and horizon X61; b MMUW 2021-I-048, paratype, cranidium, section Le I, sample 1-7; c MMUW 2021-I-061, paratype, cephalon with partial thorax, section Le I, sample 1-7; d MMUW 2021-I-042, paratype, cranidium, section Le XV, sample 1-30; e MMUW 2021-I-043, paratype, cranidium, section Le XV, sample 1-25; f MMUW 2021-I-045, paratype, cranidium with detached librigena and thorax of immature individual, section Le XV, sample 1-st; h MMUW 2021-I-056, paratype, latex cast of mould of slightly detached exoskeleton, ventral side with hypostome and rostral plate in place, section Le I, sample 1-7; i MMUW 2021-I-050, paratype, hypostome with slightly detached rostral plate, section Le IV, sample 1-10; j MMUW 2021-I-060, paratype, enrolled exoskeleton, ventral side showing hypostome and rostral plate with ventral side of librigena, section Le I, sample 1-9; k, I MMUW 2021-I-065, paratype, incomplete pygidium, lateral and dorsal views, section Le I, sample 1-12; m MMUW 2021-I-059, paratype, pleurae of segment 16?, section Le I, sample 1-9; n MMUW 2021-I-041, paratype, incomplete cranidium covered by cranidium of Parasolenopleura lemdadensis Geyer, 1998 (on left), sample locality and horizon X203; Tentatively assigned to Eccaparadoxides? hestia sp. nov.: g MMUW 2021-I-064, pygidium of immature individual, section Le I, sample 1-12.5. Dorsal views if not otherwise noted. All specimens from Jbel Wawrmast Formation, Kymataspis arenosa Zone, Lemdad Syncline, western High Atlas, Morocco. Scale bars $1 \mathrm{~mm}$ except in a and $\mathbf{b}$ $(5 \mathrm{~mm})$

moderate sag. convexity and with median node. Occipital furrow with shallow median section which curves slightly forward and distinctive lateral sections almost normal to axis.

Palpebral lobes arcuate, exsag. ca. $45-52 \%$ max. of cephalic length (ratio slightly decreasing with growing sclerite size), moderately elevated, mostly uniformly convex in tr. section; centre in adult individuals opposite middle part of L2 to S2 at axial furrow, anterior end of ocular suture opposite origin of S4 or slightly posterior to it at axial furrow, posterior end opposite occipital furrow, posterior ends always slightly to distinctly more abaxial than anterior ends; comparatively broad (tr.), ca. $9-11 \%$ of max. cranidial width on exterior of cuticle, narrower (tr.) on internal moulds. Palpebral lobe confluent with eye ridge without distinct angulation. Eye ridge nearly straight, directed only slightly obliquely to axis but sometimes curves anteriorly, clearly tapers toward axial furrow and fades, extends into facial lines on preocular areas.

Intraocular genae ca. $19-25 \%$ of max. cranidial width across centre of palpebral lobes and ca. $40-45 \%$ of max. cephalic length (exsag.) adjacent to axial furrow; with slightly elevated oval bacculae in the posteroadaxial sector (e.g., Fig. 13a).

Preglabellar field absent. Preocular areas irregularly subtrapezoidal.

Anterior branches of facial suture directed obliquely anterolaterally from origin at anterior ends of ocular suture, form straight line that changes into an adaxial curve commencing at about the posterior third of the anterior border; abaxial tips of anterior border located approximately in front of the abaxial margin of palpebral furrow or in front of adaxial half of the palpebral lobe. Posterior branches short to moderately long, directed steeply abaxially from posterior ends of palpebral lobes.

Anterior border elevated, with moderate curvature of anterior margin in the central sector, anterolateral parts of anterior margin weakly curved, posterior margin of anterior border more strongly posteriorly directed so that it widens slightly in exsag. direction; surface with moderate sag. and exsag. convexity.

Posterior border relatively narrow (exsag.), subequal in exsag. breadth or slightly wider toward facial suture, moderately elevated, weakly sigmoid in dorsal view. Posterior border furrow moderately deep and broad throughout its course on the dorsal side of the cranidium.

Librigena with fairly narrow ocular platform. Lateral border moderately broad (tr.), slightly convex in tr. section, subequal in width for most of its exsag. expansion, slightly wider posteriorly, grades into a moderately long and moderately strong, uniformly tapering genal spine with gentle curvature, base relatively wide, without much change in curvature of lateral margin; posterior tips of genal spines opposite anterior half of thorax. Posterior border fairly narrow, lateral border and genal spine covered with roughly subparallel terrace ridges.

Rostral plate mirrors outline of cranidial anterior border, with moderate to pronounced curvature centrally, anterolateral margin weakly curved, posterior margin more strongly posteriorly directed so that it slightly widens exsag.; surface with moderate sag. and exsag. convexity.

Hypostome with oval middle body and subrectangular posterior part framed by lateral and posterior borders; sag. length about two-thirds of max. width. Posterior border transverse medially, with lateral sections directed obliquely laterally and anteriorly, extending into relatively long, variably curved marginal spine.

Middle body of hypostome with convex anterior lobe which measures ca. $80-85 \%$ of hypostomal length on sag. line; lateral parts of anterior lobe distinctly dorsally extended. Posterior lobe of middle body semilunate, distinctly convex in sag. and exsag. profile, separated from anterior body laterally by distinct oblique furrow. Maculae not recognised.

Thorax known from a few more-or-less complete specimens and several disarticulated segments, with up to 16 segments. Segments with relatively uniform morphology, show progressive anterior to posterior size decrease, combined with shorter pleural spine length (tr.), width of axial rings (tr.), and increasing rearward orientation of pleural spines. Axial ring widest at segment 2 where it is about one-third width of segment, successively narrows to segment 16 , where it has a width of ca. $55 \%$ width of axial ring 
at segment 2 and ca. 55\% width of entire segment 16 . Axial rings with weak forward curvature anteriorly and slightly concave posterior margin, and thus slightly constricted medially. Lateral parts near axial furrows distinctly swollen, indicating attachment sites of ventral muscles. Articulating half-ring moderately wide (sag. and exsag.). Axial rings in segments 3-6 with more pronounced constriction, indicate possibility of dorsal inclination against each other and against segments 2 and 7 during enrolment so that the carapace may have been distinctly concave in lateral view with maximum flexure.

Thoracic pleurae divided by a moderately deep, spindleshaped, well-developed pleural furrow which originates adaxially near anterolateral corners of axial ring and runs oblique to axis to end at slightly more than half exsag. width; abaxial termination of pleural furrows located ca. one quarter of pleural length (tr.) from pleural tips in anterior segments, at about one-third to half tr. pleural length in the middle part of the thorax, and in the adaxial half of the pleurae in posterior segments. Boundary between pleural spine and adaxial part of pleura marked by faint triangular fulcral process. Pleural spines long, more-or-less falcate, moderately posteriorly curved in anterior half of thorax. Pleural spines progressively longer in larger segments. They curve more strongly towards the posterior and are broader in segments ca. 10-16. Posterior segments 14-16 have blade-like, overlapping pleural spines that form fan-shaped structure together with pygidium, with pleurae broadest opposite distal end of pleural furrow (Fig. 13m). Tips of pleural spines in segment 16 posterior to posterior pygidial margin (Fig. 12c).

Pygidium longitudinally suboval in outline, maximum tr. width at about midlength. Posterior margin moderately wide (tr.), weakly curved to nearly straight in dorsal view, extends into lateral margin without angulation or spines. Axis subtriangular in outline, with rounded posterior margin, rests on low, indistinctly defined socle, slightly more than half of pygidial length; only one axial ring defined by a straight furrow. Pleural fields smooth, grade into a longitudinal, low raised area along lateral border in anterior half. No pygidial border or border furrow developed. Ventral doublure of pygidium very broad.

Exterior of cuticle largely smooth. Glabella occasionally with recognisable terrace lines, anterior border and lateral cephalic border with terrace ridges parallel to anterior, lateral and posterior margins.

Ontogeny. Immature cranidia of Eccaparadoxides? hestia sp. nov. differ from those of adult individuals in having a relatively narrower glabella with posteriorly somewhat more parallel lateral margins; distinctly broader (rel.) fixigenae; narrower and more distinctly arcuate palpebral lobes; and a more evenly curved anterior margin of the cranidium (Fig. 13e, f). A very small pygidium is tentatively assigned to E.? hestia and appears to indicate considerable allometric growth (Fig. 13g): It has a broadly subovate outline with weakly curved lateral margins developing into a convex curvature of the posterior margin. The axis is triangular and more than two-thirds of the pygidial length.

Discussion. Eccaparadoxides? hestia sp. nov. is a relatively distinctive paradoxidine trilobite with a general Eccaparadoxides-type morphology. It differs, however, in a number of characters so that a confident generic assignment is not possible. Eccaparadoxides-type characters include the course of the anterior branches of the facial suture and the long arcuate palpebral lobes with its anterior tips at S4. By contrast, the relatively broad glabella with faint lateral glabellar furrows S3 and S4 and the tr. width of the palpebral lobes differ considerably from the typical characters seen in the pusillus group. The thorax is fairly broad, with a fan-like aspect of the posterior third, similar to the thoraxes in species of Acadoparadoxides. The pygidium has a slender subovate outline with a nearly straight posterior margin, with its widest part at about half-length. The posterolateral "corners" are gently rounded.

Eccaparadoxides? hestia resembles the more-or-less coeval E.? sdzuyi from Spain. The taxonomic problems with the latter species have been discussed above. Although there is a general similarity in their pygidia as far as is known based on the the imperfect material from Spain, there are considerable differences in their cranidia, such as the narrower glabella with a shorter anterior part and narrower fixigenae in E.? sdzuyi.

In addition, Eccaparadoxides? hestia resembles immature specimens of Acadoparadoxides? pinus and E.? insularis. Both Scandinavian species are distinguished by narrower outlines of the pygidia, and the pygidial axis in A.? pinus is distinctly longer. In addition, $A$.? pinus has thoracic pleurae that do not extend as far laterally, and A.? pinus and E.? insularis differ in other characters of the cranidium, particularly in having shorter palpebral lobes in adult or nearly adult individuals (see Westergård 1936: pls. VI, VII).

Biostratigraphy. Eccaparadoxides? hestia sp. nov. ranges through the entire Kymataspis arenosa Biozone in the western Anti-Atlas and can be used as an auxiliary index fossil for this zone. It is even more abundant than $K$. arenosa, and is the most common trilobite of these strata and characteristic of the upper Agdzian (middle-upper Wuliuan) strata in the region. However, its sclerites are often difficult to assign confidently to the species. In addition, the species is unknown from coeval strata in the western, central and eastern Anti-Atlas, where $K$. arenosa occurs.

Acknowledgements Study and loan of the specimens from the Doberlug core was made possible by Angela Ehling (collections of 
the Bundesanstalt für Geowissenschaften und Rohstoffe, Berlin-Spandau), which is gratefully acknowledged. The authors thank Lukaš Laibl (Prague) for kindly providing photos of Eccaparadoxides pusillus from Bohemia in the collections of the National Museum Prague. Scott Morrison and Terry Fletcher helped with the literature, and the late Patrick Bommel provided a rare complete specimen of E. epimetheus sp. nov. for illustration. We are also grateful to Per Ahlberg (Lund) and Jakub Nowicki (Warsaw) for their constructive and helpful reviews.

Funding Open Access funding enabled and organized by Projekt DEAL.

Open Access This article is licensed under a Creative Commons Attribution 4.0 International License, which permits use, sharing, adaptation, distribution and reproduction in any medium or format, as long as you give appropriate credit to the original author(s) and the source, provide a link to the Creative Commons licence, and indicate if changes were made. The images or other third party material in this article are included in the article's Creative Commons licence, unless indicated otherwise in a credit line to the material. If material is not included in the article's Creative Commons licence and your intended use is not permitted by statutory regulation or exceeds the permitted use, you will need to obtain permission directly from the copyright holder. To view a copy of this licence, visit http://creativecommons.org/licenses/by/4.0/.

\section{References}

Álvaro, J.J., P. Courjault-Radé, J.J. Chauvel, M.P. Dabard, F. Debrenne, R. Feist, G.L. Pillola, E. Vennin, and D. Vizcaïno. 1998. Nouveau découpage stratigraphique du Cambrien des nappes de Pardailhan et du Minervois (versant sud de la Montagne noire). Géologie de la France 2: 3-12.

Angelin, N.P. 1854. Palaeontologia Scandinavica. Pars I. Crustacea Formationis Transitionis. Fasc. II. Academiae Regiae Scientiarum Suecanae, i-ix + 21-92. Lipsiæ (=Leipzig): T.O. Weigel.

Angelin, N.P. 1878. Palaeontologia Scandinavica. I: Crustacea formationis transitionis, 2nd ed., ed. G. Lindström, 1-96. Stockholm: Norstedt.

Asklund, B., and P. Thorslund. 1935. Fjällkedjerandens bergbyggnad i norra Jämtland och Ångermanland. Sveriges Geologiska Undersökning (C: Avhandlingar \& Uppsatser) 382: 1-110.

Astashkin, V.L., A.Y. Zhuravlev, T.V. Pegel', L.N. Repina, A.Y. Rozanov, Y.Y. Shabanov, V.V. Sundukov, and S.S. Sukhov. 1992. Osnoviye razrezy kembriya Sibirskoy platformy i ikh korreltyatsiya. In Kembriy Sibiri. Rossiyskaya Akademiya Nauk, Sibirskoe otdelenie, eds. L.N. Repina, and A.Y. Rozanov. Trudy Instituta Geologii i Geofiziki 788: 62-114.

Axheimer, N. 2006. The Middle Cambrian eodiscoid trilobite Dawsonia oelandica (Westergård, 1936). Journal of Paleontology 80: 193-200.

Barrande, J. 1846. Notice préliminaire sur le systême silurien et les trilobites de Bohême, i-vi + 1-96. Leipsic (=Leipzig): C.L. Hirschfeld.

Barrande, J. 1852. Système Silurien du Centre de la Bohême. $1^{\text {ère }}$ Partie. Recherches paléontologiques. Crustacés, Trilobites, vol. 1, 1-935. Prague/Paris.

Barrande, J. 1872. Système Silurien du Centre de la Bohême. $1^{\text {ère }}$ Partie. Recherches paléontologiques. Supplément au Vol. I. Trilobites, Crustacés divers et Poissons, 1-647. Prague/Paris.

Barrois, C. 1882. Recherches sur les terrains anciens des Asturies et de la Galice. Mémoire de la Société Géologique du Nord 2: 1-630.

Bednarczyk, W. 1970. Trilobites (sic!) fauna of the Lower Paradoxides oelandicus stage from the Brzechów area in the western part of the Świętokrzyskie Mts. Bulletin de l'Académie Polonaise des Sciences, Séries des sciences chimiques, géologiques et géographiques 18: 29-35.

Bednarczyk, W. 1972. The Precambrian and Cambrian of the Łeba Elevation (NW Poland). Acta Geologica Polonica 22: 685-710. (in Polish with English abstract).

Bednarczyk, W. 1984. Biostratigraphy of the Cambrian deposits in the Łeba area. Acta Geologica Polonica 34: 95-110.

Bengtson, S., and A. Urbanek. 1986. Rhabdotubus, a Middle Cambrian rhabdopleurid hemichordate. Lethaia 19: 293-308.

Berg-Madsen, V. 1985. The Middle Cambrian of Bornholm, Denmark: A stratigraphical revision of the lower alum shale and associated anthraconites. Geologiska Föreningen i Stockholm Förhandlingar 106: 357-376. https://doi.org/10.1080/11035898509454664.

Billings, E. 1874. Palceozoic Fossils Vol. 2, Part 1, 1-144. Montreal: Geological Survey of Canada.

Brøgger, W.C. 1878. Om Paradoxidesskifrene ved Krekling. Nyt Magazin for Naturvidenskaberne 24: 18-88.

Brongniart, A. 1822. Les Trilobites. In Histoire naturelle des crustacés fossiles, sous les rapports zoologiques et géologiques, eds., Brongniart, A. and A.-G. Desmarest, 1-65. Paris: F.-G. Levrault.

Cavet, P., M. Gruet, and J. Pillet. 1967. Les trilobites mésocambriens de Cléré-sur-Layon (Massif armoricain). Bulletin de la Société géologique de France 7(IX): 750-757.

Chernysheva, N.E. ed., 1971. Amginskiy yarus Altae-Sayanskoy oblasti. Trudy Sibirskoe nauchno-issledovatel'skiy instituta geologii, geofiziki i mineral'nogo syr'ya (Serya paleontologiya i stratigrafiya) III, 1-267.

Chernysheva, N.E. 1953. Srednekembriyskie trilobity Vostochnoy Sibiri. Chast' 1. Trudy Vsesoyuznogo nauchno-issledovatel'skogo geologicheskogo Instituta, 1953: 1-95.

Chernysheva, N.E., ed. 1965. Kembriyskaya Sistema. Stratigrafiya SSSR 3: 1-596.

Chirivella Martorell, J.B. 2008. Sistemática de los Trilobites, bioestratigrafía y paleoecología del límite Leoniense-Caesaraugustiense (Cámbrico medio) en las Cadenas Ibéricas (NE de España), 1-226. Unpublished Ph.D. Thesis, Universitat de València.

Cobbold, E.S. 1911. Trilobites from the Paradoxides Beds of Comley (Shropshire), with notes on some of the associated Brachiopoda by Charles Alfred Matley. Quarterly Journal of the Geological Society LXVII: 282-310.

Courtessole, R. 1967. Contribution à la connaissance de la Paléontologie et de la Stratigraphie du Cambrian moyen de la Montagne Noire (versante méridional). Bulletin de la Société d'Histoire Naturelle de Toulouse 103: 491-526.

Courtessole, R., J. Pillet, and D. Vizcaïno. 1988. Stratigraphie et paléontologie du Cambrien moyen gréseux de la Montagne Noire (versant méridional). Mémoires de la Société d'Études scientifiques de l'Aude 1988: 1-55.

Courtessole, R. 1973. Le Cambrien Moyen de la Montagne Noire. Biostratigraphie, 1-248. Toulouse: Imprimérie d'Oc.

Dawson, J.W. 1868. Acadian Geology: The geological structure, organic remains, and mineral resources of Nova Scotia, New Brunswick and Prince Edward Island, 2nd ed., 1-694. London: Macmillan.

Dean, W.T. 1982. Middle Cambrian trilobites from the Sosink Formation, Derik-Mardin district, south-eastern Turkey. Bulletin of the British Museum of Natural History (Geology) 36: 1-41.

Dean, W.T. 2005. Trilobites from the Çal Tepe Formation (Cambrian), near Seydişehir, Central Taurides, Southwestern Turkey. Turkish Journal of Earth Sciences 14: 1-71.

Destombes, J., H. Hollard, and S. Willefert. 1985. Lower Palaeozoic Rocks of Morocco. In Lower Palaeozoic Rocks of the World. Vol. 4. Lower Palaeozoic of north-western and west central Africa, ed. C.H. Holland, 91-336. Chichester etc.: Wiley. 
Dies Álvarez, M.E., A.W.A. Rushton, R. Gozalo, G.L. Pillola, E. Liñán, and P. Ahlberg. 2010. Paradoxides brachyrhachis Linnarsson, 1883 versus Paradoxides mediterraneus Pompeckj, 1901: A problematic determination. GFF 132: 95-104.

Dumicz, M., E. Tomczykowa, and L. Wójcik. 1970. On the occurrence of Middle Cambrian trilobites in the Khobdo Region (Western Mongolia). Rocznik Polskiego Towarzystwa Geologicznego 40: 287-310.

Egorova, L.I. 1967. Nekotorye trilobity nizhnego i srednego kembriya Sibirskoy platformy. Paleontologicheskiy Zhurnal 1967(1): 68-78.

Egorova, L.I., and V.E. Savitsky. 1969. Stratigrafiya i biofatsii kembriya Sibirskoy platformy (Zapadnoe Prianabar'e). Trudy Sibirskoe nauchno-issledovatel'skiy instituta geologii, geofiziki i mineral'nogo syr'ya 43: 1-407.

Egorova, L.I., Y.Y. Shabanov, A.Y. Rozanov, V.E. Savitskiy, N.E. Chernysheva, and B.B. Shishkin. 1976. Elanskiy i kuonamskiy fatsiostratotipy nizhney granitsy srednego kembriya Sibiri. Trudy Sibirskoe nauchno-issledovatel'skiy instituta geologii, geofiziki $i$ mineral'nogo syr'ya 211: 1-166.

Egorova, L.I., Y.Y. Shbanov, T.V. Pegel', V.E. Savitskiy, S.S. Sukhov, and N.E. Chernysheva. 1982. Mayskiy yarus stratotipicheskoy mestnosti (sredniy kembriy yugo-vostoko Sibirskoy platformy). Akademiya Nauk SSSR, Mezhvedomstvennyy Stratigraficheskiy Komitet SSSR, Trudy 8: 1-166.

Emmrich, H.F. 1839. De trilobitis, dissertatio petrefactologica quam consensu et auctoritate amplissimi philosorum ordinis in alma litterarum universitate Fridericia Guilelma pro summis in philosophia honoribus, 1-56. Berolini (=Berlin): Nietack.

Esteve, J. 2013. Revisión del enrollamiento en los trilobites del Cámbrico español y su implicación en la evolución de los trilobites. Estudios Geológicos 69(2): 209-225.

Esteve, J. 2014. Intraspecific variability in paradoxidid trilobites from the Purujosa trilobite assemblage (middle Cambrian, northeast Spain). Acta Palaeontologica Polonica 59: 215-240.

Fatka, O. 2006. Biostratigraphy of the Jince Formation (Middle Cambrian) in the Př́bram-Jince Basin: Historical review. Acta Universitatis Carolinae (Geologica) 47: 53-61.

Fatka, O., and M. Szabad. 2014. Cambrian Biostratigraphy in the Př́ibram-Jince Basin (Barrandian area, Czech Republic). Bulletin of Geosciences 89: 413-429.

Fletcher, T.P. 2005. Holaspid variation in the solenopleurid trilobite Parasolenopleura gregaria (Billings, 1865) from the Cambrian of Newfoundland. Palaeontology 48: 1075-1089.

Fletcher, T.P. 2006. Bedrock geology of the Cape St. Mary's Peninsula, Southwest Avalon Peninsula, Newfoundland (includes parts of the map sheets $1 \mathrm{M} / 1,1 \mathrm{~N} / 4,1 \mathrm{~L} / 16$ and $1 \mathrm{~K} / 13$ ). Government of Newfoundland and Labrador, Geological Survey, Department of Natural Resources, St John's, Report 06-02: 1-117.

Fletcher, T.P. 2007. Correlating the zones of 'Paradoxides hicksii' and 'Paradoxides davidis' in Cambrian Series 3. Memoirs of the Association of Australasian Palaeontologists 33: 35-56.

Geyer, G. 1998. Intercontinental, trilobite-based correlation of the Moroccan early Middle Cambrian. Canadian Journal of Earth Sciences 35: 374-401.

Geyer, G., and J.M. Malinky. 2019. Helcionelloid molluscs and hyoliths from the Miaolingian (middle Cambrian) of the subsurface of the Delitzsch-Torgau-Doberlug Syncline, northern Saxony, Germany. PalZ. Paläontologische Zeitschrift 94: 271-293.

Geyer, G., and T. Vincent. 2015. The Paradoxides puzzle resolved: The appearance of the oldest paradoxidines and its bearing on the Cambrian Series 3 lower boundary. PalZ. Paläontologische Zeitschrift 89: 335-398.

Geyer, G., and E. Landing. 2006. Ediacaran-Cambrian depositional environments and stratigraphy of the western Atlas regions. In Morocco 2006 - Ediacaran-Cambrian depositional environments and stratigraphy of the western Atlas regions. Beringeria, Special Issue, eds. G. Geyer, and E. Landing, vol. 6, 47-120 (=UCL Maghreb Petroleum Research Group, Infracambrian/Early Palaeozic Field Guide Series 1).

Geyer, G., E. Landing, and W. Heldmaier. 1995. Faunas and depositional environments of the Cambrian of the Moroccan Atlas region. In MOROCCO '95-the Lower-Middle Cambrian standard of western Gondwana, eds. G. Geyer, and E. Landing. Beringeria, Special Issue 2: 47-119.

Gil-Cid, M.D. 1970. Nota sobre los nuevos yacimientos de Trilobites del Cámbrico medio de Murero (Zaragoza). Estudios Geológicos 26: $163-172$.

Gil-Cid, M.D. 1982. Hallazgo de Paradoxides (Eccaparadoxides) brachyrhachis Linnarsson 1883, en el Cámbrico Medio de Zafra (Badajoz). Boletín Geológico y Minero 93: 10-14.

Gozalo, R., E. Liñán, T. Palacios, J.A. Gámez Vintaned, and E. Mayoral. 2003. The Cambrian of the Iberian Peninsula: An overview. Geologica Acta 1: 103-112.

Gozalo, R., E. Bernárdez, J.B. Chirvella Martorell, and E. Liñán. 2011. Trilobites del Cámbrico medio del Cueto Negro (Asturias, NE de España). Boletín Geológico y Minero 122: 71-82.

Gozalo, R., E. Liñán, J.A. Gámez Vintaned, M.E. Dies Álvarez, J.B. Chirivella Martorell, S. Zamora, J. Esteve, and E. Mayoral. 2008. The Cambrian of the Cadenas Ibéricas (NE Spain) and its trilobites. In Advances in Trilobite Research, eds. I. Rábano, R. Gozalo, and D. Garcia-Bellido. Cuadernos del Museo Geominero 9: $137-151$.

Grönwall, K.A. 1902. Bornholms Paradoxideslag og deres fauna. Danmarks geologiske Undersфgelse (2. Rakke) 13: i-xi + 1-230.

Hawle, I., and A.J.C. Corda. 1847. Prodrom einer Monographie der böhmischen Trilobiten. Abhandlungen der königlichen böhmischen Gesellschaft der Wissenschaften 5: 119-292.

Hicks, H. 1871. Descriptions of New Species of Fossils from the Longmynd Rocks of St. David's. In On the Ancient Rocks of St. David's Promontory, South Wales, and their Fossil Contents, eds. R. Harkness, and H. Hicks. Quarterly Journal of the Geological Society XXVII: 399-404.

Hicks, H. 1895. On the genus Plutonides (non Plutonia) from the Cambrian rocks of St. David's. Geological Magazine (decade 4) 2: 230-231.

Hutchinson, R.D. 1962. Cambrian stratigraphy and trilobite faunas of southeastern Newfoundland. Geological Survey of Canada Bulletin 88: 1-156.

Illing, V.C. 1916. The Paradoxidian fauna of a part of the Stockingford Shales. Quarterly Journal of the Geological Society LXXI(for 1915): 386-450.

Kim, D.H., S.R. Westrop, and E. Landing. 2002. Middle Cambrian (Acadian Series), Conocoryphe and paradoxidid trilobites from the upper Chamberlain's Brook Formation, Newfoundland and New Brunswick. Journal of Paleontology 76: 822-842.

Kordule, V. 1990. Rejkocephalus, a new paradoxidid genus from the Middle Cambrian of Bohemia (Trilobita). Véstník Ústředního Ústavu Geologického 65: 55-60.

Kordule, V. 1999. New data about paradoxid trilobites from Middle Cambrian of Central Bohemia. Bulletin of Czech Geological Survey 74: 17-26.

Korovnikov, I.V., and Y.Y. Shabanov. 2016. Trilobites and biostratigraphy of the Kuonamka Formation, northern Siberian Platform (Olenek River). Russian Geology and Geophysics 57: 562-573.

Laibl, L., J. Esteve, and O. Fatka. 2016. Enrollment and thoracic morphology in paradoxidid trilobites from the Cambrian of the Czech Republic. Fossil Imprint 72: 161-171.

Lake, P. 1935. A Monograph of the British Cambrian Trilobites. Part IX. Palaeontographical Society, Monographs 88(399): 197-224.

Lendzion, K. 1982. Korelacja stratygraficzna kambru syneklizy perybałtyckiej w Polsce (Stratigraphic correlation of the 
Cambrian in the Peribaltic Syneclise in Poland). Przeglad Geologiczny 30: 213-219. (in Polish with English abstract).

Lermontova, E.V. 1940. VI Tip - Arthropoda. In Atlas rukovodyashchikh form iskopaemykh fauna USSR. 1, Kembriy, ed. A. Vologdin, 112-157. Moskva/Leningrad: Gosgeoltekhizdat.

Liñán, E. 1984. Introducción al problema de la paleogeografía del Cámbrico de Ossa-Morena. Cuadernos do Laboratorio Geológico de Laxe 8: 283-314.

Liñán, E., and R. Gozalo. 1986. Trilobites del Cámbrico inferior y medio de Murero (Cordillera Ibérica). Memorias del Museo Paleontologico de la Universidad de Zaragoza 2: 7-104.

Liñán, E., A. Perejón, R. Gozalo, E. Moreno-Eiris, and J.T. de Oliveira. 2004. The Cambrian System in Iberia, 1-63. Madrid: Instituto Geológico y Minero de España.

Liñán-Guijarro, E. 1978. Bioestratigrafía de la Sierra de Córdoba. Tesis Doctoral de la Universidad de Granada 191: 1-212.

Linnarsson, J.G.O. 1879. Om faunan i kalken med Conocoryphe exsulans ('Coronatuskalken'). Sveriges Geologiska Undersökning ( $C$ : Avhandlingar \& Uppsatser) 35: 1-31.

Linnarsson, G. 1883. De undre Paradoxideslagren vid Andrarum. Sveriges Geologiska Undersökning (C: Avhandlingar \& Uppsatser) 54: 1-47.

Loi, A., G.L. Pillola, and E. Leone. 1995. The Cambrian and Early Ordovician of south-western Sardinia. Rediconti del Seminario della Facoltà di Scienze dell'Università di Cagliari, Suppl. 65: 63-81.

Matthew, G.F. 1883. Illustrations of the fauna of the St. John Group. No. 1. The Paradoxides. Transactions of the Royal Society of Canada 2: 271-279.

Miquel, J. 1905. Essai sur le Cambrien de la Montagne Noire. Coulouma. L'Acadien. Bulletin de la Société géologique de France 5: $465-483$

Nowicki, J., and A. Żylińska. 2019. The first occurrence of the earliest species of Acadoparadoxides outside West Gondwana (Cambrian; Holy Cross Mountains, Poland). Geological Magazine 156: 1027-1051.

Orłowski, S. 1957. On the presence of Paradoxides ölandicus Beds in the Holy Cross Mountains. Bulletin de l'Académie Polonaise des Sciences (Cl. III) 5: 769-772.

Orłowski, S. 1959a. Paradoxidae from lower Middle Cambrian strata in the vicinity of Sandomierz (Central Poland). Bulletin de l'Académie Polonaise des Sciences (Série des sciences chimiques, géologiques et géographiques) VII: 441-446.

Orłowski, S. 1959b. Ellipsocephalidae from the Lower Beds of the Middle Cambrian in the vicinity of Sandomierz (Central Poland). Bulletin de l'Académie Polonaise des Sciences (Série des sciences chimiques, géologiques et géographiques) VII: 515-520.

Orłowski, S. 1964. Kambr środkowy i jego fauna we wschodniej części Gór Świętokrzyskich [Middle Cambrian and its fauna in the eastern part of the Holy Cross Mts.]. Studia Geologica Polonica 16: 1-94. (in Polish with English summary).

Pajchlowa, M., ed. 1990. Budowa geologiczna Polski/Geology of Poland. Vol. 3, Atlas of guide and characteristic fossils. Pt. 1a, Paleozoic (including Upper Proterozoic). Warsaw: Publishing House Wydawnictwa Geologiczne. (in Polish, English version published in 1991).

Picard, E. 1928. Das Algonkium von Rotstein bei Liebenwerda im Vergleich mit demjenigen im Sarkatal bei Prag und über Cambrium bei Dobrilugk. Zeitschrift der deutschen geologischen Gesellschaft 80, Monatsberichte 1: 20-32.

Picard, E., and W. Gothan. 1931. Die wissenschaftlichen Ergebnisse der Staatlichen Tiefbohrungen bei Dobrilugk, N.-L. 1927-1931. Jahrbuch des Halleschen Verbandes zur Erforschung der mitteldeutschen Bodenschätze (N. F.) 10: 131-141.
Pillet, J. 1988. Paléontologie. In Stratigraphie et paléontologie du Cambrien moyen gréseux de la Montagne Noire (versant méridional). Mémoires de la Société des Etudes Scientifiques de l'Aude, eds. R. Courtessole, J. Pillet, and D. Vizcaïno, 35-55.

Poletaeva, O.K. 1955. Trilobity. In Atlas rukovodyashtchikh form iskopaemykh fauny i flory Zapadnoy Sibiri, Tom I. Zapadno-sibirskoe Geologicheskoe Upravlenie, Tomskiy ordena trudovogo krasnogo znameni politekhnicheskiy instituta imeni S.M. Kirova, ed. L.L. Khalfin, 108-130. Moscow: Gosudarstvennoe nauchno-tekhnicheskoe izdatel'vo literatury po geologii i okhrane nedr.

Poletaeva, O.K. 1960. Opisanie trilobitov. In Biostratigrafiya paleozoya Sayano-Altayskoy gornoy oblasti, ed. L.L. Khalfin. Trudy Sibirskoe nauchno-issledvatel'skogo instituta geologii, geofiziki i mineral'nogo syr'ya 1(19): 152-253.

Pompeckj, J.F. 1901. Versteinerungen der Paradoxides-Stufe von La Cabitza in Sardinien und Bemerkungen zur Gliederung des sardischen Cambrium. Zeitschrift der deutschen geologischen Gesellschaft 53: 1-23.

Pompeckj, J.F. 1896. Die Fauna des Cambrium von Tejřovic und Skrej in Böhmen. Jahrbuch der K. u. K. Geologischen Reichsanstalt, Wien XLV(for 1895): 495-614.

Prado, M.C., E. Verneuil, and J. Barrande. 1860. Sur l'éxistence de la faune primordial dans la Chaîne Cantabrique. Bulletin de la Société géologique de France (2éme Série) 17: 516-542.

Repina, L.N. 1969. Trilobity nizhnego i srednego kembriya yuga Sibiri (nadsmeystvo Redlichioidea). Chast II. Akademiya Nauk SSSR, Sibirskoe otdelenie, Trudy Instituta Geologii i Geofiziki 67: 1-107.

Rushton, A.W.A., T. Weidner, and J.O.R. Ebbestad. 2016. Paradoxidid trilobites from a mid-Cambrian (Series 3, stage 5) limestone concretion from Jämtland, central Sweden. Bulletin of Geosciences 91: 515-552.

Salter, J.W. 1859. On the fossils of the Lingula-flags or "Zone Primordiale." Quarterly Journal of the Geological Society 15: 551-555.

Salter, J.W., and H. Hicks. 1869. On some Fossils from the "Menevian Group." Quarterly Journal and Proceedings of the Geological Society XXV: 51-57.

Sampelayo, P.H. 1935. El Sistema Cambriano. Memorias del Instituto Geológico y Minero de España. Explicación del Nuevo Mapa Geológico de España 1: 291-528.

Schmidt, E.W. 1944. Die mittelkambrische Fauna von Doberlug. Jahrbuch der Reichstelle für Bodenforschung 62: 344-402.

Sdzuy, K. 1957. Revision der mittelkambrischen Trilobiten von Doberlug. Senckenbergiana lethaea 38: 7-28.

Sdzuy, K. 1958. Neue Trilobiten aus dem Mittelkambrium von Spanien. Senckenbergiana lethaea 39: 235-253.

Sdzuy, K. 1961. Neue Funde aus den Leimitz-Schiefern (Tremadoc). Senckenbergiana lethaea 42: 227-243.

Sdzuy, K. 1968. Trilobites del Cámbrico Medio de Asturias. Trabajos de Geologia, Facultad de Ciencias, Universidad de Oviedo (1967)1: 77-133.

Sdzuy, K., E. Liñán, and R. Gozalo. 1999. The Leonian Stage (early Middle Cambrian): A unit for Cambrian correlation in the Mediterranean subprovince. Geological Magazine 136: 39-48.

Sjögren, A. 1872. Om några försteningar i Ölands kambriska lager. Geologiska Föreningens i Stockholm Förhandlingar 1(18721873): 67-80.

Šnajdr, M. 1957. O nových trilobitech z českého kambria. Vestnik Ústředního ústavu geologického 32: 235-244.

Šnajdr, M. 1958. Trilobiti českého středního kambria. Rozpravy Ústředního ústavu geologického 24: 1-280.

Šnajdr, M. 1978. Anomalous carapaces of Bohemian paradoxid trilobites. Sbornik geologickych Věd (Paleontologia) 20: 7-31.

Šnajdr, M. 1986. Two new paradoxidid trilobites from the Jince Formation (Middle Cambrian, Czechoslovakia). Vestnik Ústředního ústavu geologického 61: 169-174. 
Solov'ev, I.A. 1969. Novye vidy Paradoxides (trilobity) iz goryuchikh slantsev amginskogo yarusa Severnoy Yakutii. Uchenie zapiyski, NIIGA, Paleontologiya i biostratigrafiya 25: 9-20.

Solov'ev, I.A. 1988. New Cambrian trilobite suite from the Siberian Platform. Paleontologicheskiy Zhurnal 1988(3): 56-63.

Szabad, M., and J. Valíček. 1997. Paleontologický výzkum lokality Studená hora u Týrovic. Zprávy o geologických výzkumech 1996: 135 .

Thoral, M. 1935. Contribution à l'étude géologique des Monts de Lacaune et des terrains cambriens et ordoviciens de la Montagne Noire. Bulletin de la Service de Carte géologique de France 192 (38): 1-318.

Vaněk, J., J. Valíček, and V. Vokáč. 1999. Plutonides hicksii (SALTER) from the Middle Cambrian of the Skryje - Týřovice area (Czech Republic). Palaeontologia Bohemiae V: 36-38.

Weidner, T., and A.T. Nielsen. 2014. A highly diverse trilobite fauna with Avalonian affinities from the Middle Cambrian Acidusus atavus Zone (Drumian Stage) of Bornholm, Denmark. Journal of Systematic Palaeontology 12: 23-92. https://doi.org/10.1080/ 14772019.2012.740080.

Weidner, T., A.W.A. Rushton, and J.Ø.R. Ebbestad. 2014. A paradoxidid-agnostoid fauna from the mid-Cambrian (Stage 5) of the Caledonian Lower Allochthon on Tåsjöberget, Ångermanland, Sweden. GFF 136(4): 513-530.
Westergård, A.H. 1936. Paradoxides oelandicus Beds of Öland. Sveriges Geologiska Undersökning (C: Avhandlingar och uppsatser) 394: 1-66.

Westergård, A.H. 1953. Non-agnostidean trilobites of the Middle Cambrian of Sweden III. Sveriges Geologiska Undersökning (C: Avhandlingar och uppsatser) 526: 1-59.

Wolvers, H.M., and J. Maletz. 2016. The benthic graptolite Sphenoecium mesocambricus (Öpik, 1933) from the Middle Cambrian of Krekling, Oslo Region, Norway. Norwegian Journal of Geology 96: 311-318.

Żylińska, A. 2013. The oldest Cambrian trilobites from the Holy Cross Mountains, Poland: Taxonomic, stratigraphic and biogeographic reappraisal. Acta Geologica Polonica 63: 57-87.

Żylińska, A., and M. Masiak. 2007. Cambrian trilobites from Brzechów, Holy Cross Mountains (Poland) and their significance in stratigraphic correlation and biogeographic reconstructions. Geological Magazine 144: 661-686.

Żylińska, A., and Z. Szczepanik. 2009. Trilobite and acritarch assemblages from the Lower-Middle Cambrian boundary interval in the Holy Cross Mountains (Poland). Acta Geologica Polonica 59(4): 413-458. 